\title{
THE COLONIAL ORIGINS OF COMPARATIVE DEVELOPMENT: AN EMPIRICAL INVESTIGATION
}

\author{
Daron Acemoglu \\ Simon Johnson \\ James A. Robinson \\ Working Paper 7771 \\ http://www.nber.org/papers/w7771
NATIONAL BUREAU OF ECONOMIC RESEARCH 1050 Massachusetts Avenue
Cambridge, MA 02138
June 2000

We thank Joshua Angrist, Abhijit Banerjee, Esther Duflo, John Gallup, Chad Jones, Andrei Shleifer, and participants at the Harvard-MIT Development Economics seminar, Berkeley Political Science seminar, Columbia Social Sciences seminar, and the Stanford Social Science History Institute conference for useful comments. We also thank Robert McCaa for guiding us to the data on bishops' mortality. The views expressed herein are those of the authors and not necessarily those of the National Bureau of Economic Research.

(C) 2000 by Daron Acemoglu, Simon Johnson, and James A. Robinson. All rights reserved. Short sections of text, not to exceed two paragraphs, may be quoted without explicit permission provided that full credit, including $\odot$ notice, is given to the source. 
The Colonial Origins of Comparative Development: An Empirical Investigation Daron Acemoglu, Simon Johnson, and James A. Robinson

NBER Working Paper No. 7771

June 2000

JEL No. O11, P16, P51

\begin{abstract}
We exploit differences in the mortality rates faced by European colonialists to estimate the effect of institutions on economic performance. Our argument is that Europeans adopted very different colonization policies in different colonies, with different associated institutions. The choice of colonization strategy was, at least in part, determined by whether Europeans could settle in the colony. In places where Europeans faced high mortality rates, they could not settle and they were more likely to set up worse (extractive) institutions. These early institutions persisted to the present. We document evidence supporting these hypotheses. Exploiting differences in mortality rates faced by soldiers, bishops and sailors in the colonies in the 17th, 18th and 19th centuries as an instrument for current institutions, we estimate large effects of institutions on income per capita. Our estimates imply that differences in institutions explain approximately three-quarters of the income per capita differences across former colonies. Once we control for the effect of institutions, we find that countries in Africa or those farther away from the equator do not have lower incomes.
\end{abstract}

\author{
Daron Acemoglu \\ MIT \\ Simon Johnson \\ MIT \\ Department of Economics \\ Sloan School of Management \\ E52-371 \\ 50 Memorial Drive \\ 50 Memorial Drive \\ Cambridge, MA 02319 \\ Cambridge, MA 02319 \\ sjohnson@mit.edu \\ and NBER, Canadian Institute of \\ Advanced Research \\ daron@mit.edu \\ James A. Robinson \\ University of California \\ Department of Political Science \\ 210 Barrows Hall \\ Berkeley, CA 94720 \\ jamesar@socrates.berkeley.edu
}




\section{INTRODUCTION}

What are the fundamental causes of the large differences in income per capita across countries? Although there is still little consensus on the answer to this question, differences in institutions and property rights have received considerable attention in recent years. Countries with better "institutions", more secure property rights, and less distortionary policies will invest more in physical and human capital, and will use these factors more efficiently to achieve a greater level of income (e.g., North and Thomas, 1976, North, 1981, Jones, 1981). This view receives some support from cross-country correlations between measures of property rights and economic development (e.g., Knack and Keefer, 1995, Mauro, 1995, Barro, 1998, Hall and Jones, 1999, Rodrik, 1999), and from a few micro-studies that investigate the relationship between property rights and investment or output (e.g., Besley, 1995, Mazingo, 1999, Johnson, McMillan and Woodruff, 1999).

At some level, it is obvious that institutions matter. Witness, for example, the divergent paths of North and South Korea, or East and West Germany, where one part of the country stagnated under central planning and collective ownership, while the other prospered with private property and a market economy. Nevertheless, we still lack conclusive evidence that institutional differences can have a large enough effect to explain the phenomenal differences in output per capita across countries. It is quite likely that economies that are rich choose or can afford better institutions. Perhaps more important, economies that are different for a variety of reasons will differ both in their institutions and in their income per capita.

To estimate the impact of institutions on performance, we need a source of exogenous variation in institutions. In this paper, we propose differences in mortality rates faced by European settlers at the time of colonization as a possible source of such exogenous variation. ${ }^{1}$ We focus on societies that were colonized by European countries. These provide us with a set of economies that had relatively similar income levels 400 years ago and still exhibit large differences in per capita income today. Moreover, institutions in these countries were shaped, at least in part, by their colonization experience. ${ }^{2}$

\footnotetext{
${ }^{1}$ We do not argue that differences in mortality rates are the only, or even the main, cause of variation in institutions. For our empirical approach to work, all we need is that they are a source of exogenous variation.

${ }^{2}$ Young (1994) and Chazan et al. (1993) argue that the colonization policies of European powers had
} 
Our argument rests on three premises:

1. There were different types of colonization policies which created different sets of institutions. At one extreme, European powers set up "extractive states", exemplified by the Belgian colonization of the Congo. These institutions did not introduce much protection for private property, nor did they provide checks and balances against government expropriation. In fact, the main purpose of the extractive state was to transfer as much of the resources of the colony to the colonizer, with the minimum amount of investment possible.

At the other extreme, many Europeans went and settled in a number of colonies, creating what the historian Alfred Crosby (1986) calls "Neo-Europes". The settlers tried to replicate European institutions, with great emphasis on private property, and checks against government power. Primary examples of this include Australia, New Zealand, Canada, and the United States.

2. The colonization strategy was influenced by the feasibility of settlements. In particular, in places where the disease environment was not favorable to European settlement, the cards were stacked against the creation of Neo-Europes, and the formation of the extractive state was more likely.

3. The colonial state and institutions persisted even after independence.

Based on these three premises, we use the mortality rates expected by the first settlers in the colonies as an instrument for institutions. More specifically, our theory can be schematically summarized as

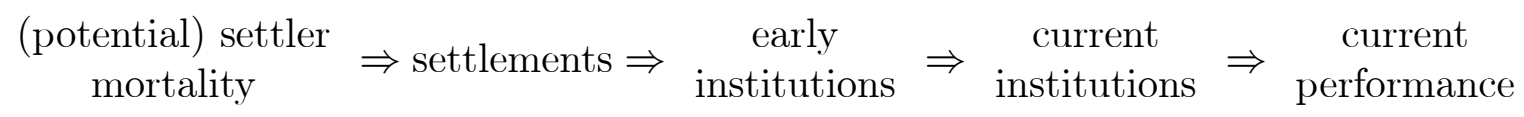

We use data on the mortality rates of soldiers, bishops, and sailors stationed in the colonies between the 17th and 19th centuries, largely based on the work of the historian Philip Curtin. These give a good indication of the mortality rates faced by settlers. Europeans were well informed about these mortality rates at the time, though they did not

a long-lasting effect on Africa. In contrast, Chabal (1986) and Herbst (2000) maintain that the current African state is a continuation of the precolonial state. Although our assessment agrees with that of Young, since we are not comparing ex-colonies to non-colonized countries, our empirical approach does not take a position on this. 
know how to control the diseases that caused these high mortality rates. Furthermore, since these mortality rates refer to fairly homogeneous groups, they are comparable across countries. We document empirically that (potential) settler mortality rates were a major determinant of settlements; that settlements were a major determinant of early institutions (in practice, institutions in 1900); that there is a strong correlation between early institutions and institutions today; and finally that current institutions have a first-order effect on current performance.

Our most parsimonious specification is to regress current performance on current institutions, and instrument the latter by settler mortality rates. Since our focus is on property rights and checks against government power, we use the "risk of expropriation" index from Political Risk Services as the proxy for institutions. This measures differences in institutions originating from different types of states and state policies. ${ }^{3}$ The first-stage relationship between this measure of institutions and settler mortality is strong. For example, settler mortality alone explains over 25 percent of the variation in this index of institutions. Using this specification, we find that institutions are a major determinant of per capita income. The estimates are quite precise, and in fact larger than the OLS estimates. They suggest that approximately three-quarters of the cross-country income differences we observe can be explained by differences in institutions.

We document that this relationship is not driven by outliers. For example, excluding Australia, New Zealand, Canada, and the United States does not change the results, nor does excluding Africa. Interestingly, we show that once the effect of institutions on economic performance is controlled for, neither distance from the equator (latitude) nor the dummy for Africa is significant. These results suggest that Africa is poorer than the rest of the world not because of pure geographic or cultural factors, but because of worse institutions.

The validity of our approach is threatened if other factors correlated with the esti-

\footnotetext{
${ }^{3}$ We do not mean to imply that government expropriation is the only institutional feature that matters. Our view is that there is a variety of institutional guarantees, including constraints on government expropriation, independent judiciary, property rights enforcement, equal access to education, and respect for civil liberties, that are important to encourage investment and growth. Expropriation risk is related to all these institutional features. In the Appendix, we report results using a variety of other measures of institutions that have been used in the literature, including the extent of the constraints on the executive coded from the Polity III dataset, an index of law and order tradition from Political Risk Services, a measure of property rights from the Heritage Foundation, a measure of rule of law from the Fraser Institute, and the efficiency of the judiciary from Business International. We obtain very similar results with all of these measures.
} 
mates of the mortality rates faced by the settlers affect income per capita. We adopt two strategies to substantiate that our results are not driven by omitted factors. First, we investigate whether institutions have an important effect once we control for a number of variables potentially correlated with settler mortality and economic outcomes. We find that none of these overturn our results; the estimates change remarkably little when we include controls for climate, geography, religion, legal origin, main colonizer, natural resources, and soil quality. Furthermore, the results are also robust to the inclusion of controls for the current disease environment (e.g., the prevalence of malaria), the current fraction of the population of European descent, and measures of ethnolinguistic fragmentation.

Naturally, it is impossible to control for all possible variables that might be correlated with settler mortality and economic outcomes. Furthermore, our empirical approach might capture the effect of settler mortality on economic performance, but working through other factors. For example, early European settlers might have brought a "culture" conducive to economic progress, which could still have an effect on income per capita today. Our instrumental variables strategy would then incorrectly assign this effect to institutions. We deal with this problem by using a simple overidentification test. Since our hypothesis is that settler mortality affected settlements; settlements affected early institutions; and early institutions persisted and formed the basis of current day institutions, we can test the validity of our approach by using measures of European migration to the colonies and of early institutions as additional instruments. We then use overidentification tests to detect whether settler mortality, or any of the other instruments, has a direct effect on current performance. The results are encouraging for our approach; they generate no evidence for a direct effect of settler mortality on economic outcomes.

We are not aware of others who have pointed out the link between settler mortality rates and institutions, though scholars such as McNeill (1976), Crosby (1986) and Diamond (1997) have discussed the influence of diseases on human history. Diamond (1997) emphasizes comparative development, but his theory is based on the geographical determinants of the incidence of the neolithic revolution. He ignores both the importance of institutions and the potential causes of divergence in more recent development, which are the main focus of our paper. Work by Gann and Duignan (1962), Robinson and Gallagher (1961), Denoon (1983), and Cain and Hopkins (1993) emphasizes that settler 
colonies such as the U.S. and New Zealand are different from other colonies, and point out that these differences were important for their economic success. Nevertheless, this literature does not develop the link between mortality, settlements and institutions.

Our argument is most closely related to work on the influence of colonial experience on institutions. Hayek (1960) argued that the British common law tradition was superior to the French civil law, which was developed during the Napoleonic era to restrain judges' interference with state policies (see also Lipset, 1994). More recently, La Porta, Lopez-deSilanes, Shleifer and Vishny $(1998,1999)$ document empirically the importance of colonial origin (the identity of the colonizer) and legal origin on current institutions. For example, they show that common law countries have better property rights and more developed financial markets. Similarly, North, Summerhill and Weingast (1998) argue that former British colonies prospered relative to former French, Spanish and Portuguese colonies because of the good economic and political institutions they inherited from Britain, and Landes (1998, chapters 19 and 20) stresses the importance of the culture inherited from Britain in these colonies. In contrast to this approach, which focuses on the identity of the colonizer, we emphasize the conditions in the colonies. Specifically, in our theory - and in the data - it is not the identity of the colonizer that matters, but whether European colonialists could safely settle in a particular location: where they could not settle, they brought worse institutions. In this respect, our argument is related to that of Engerman and Sokoloff (1997) who also emphasize institutions, but link them to factor endowments.

Empirically, our work is related to a number of other attempts to uncover the link between institutions and development, as well as to Bertocchi and Canova (1996) and Grier (1999) who investigate the effect of being a colony on postwar growth. Two papers deal with the endogeneity of institutions by using an instrumental variables approach as we do here. Mauro (1995) instruments for corruption using ethnolinguistic fragmentation. Hall and Jones (1999), in turn, who use distance from the equator as an instrument for social infrastructure because they argue that the distance from the equator is correlated with 'Western influence', which leads to good institutions. The theoretical reasoning for these instruments is not entirely convincing. It is not easy to argue that the Belgian influence in the Congo, or Western influence in the Gold Coast during the era of slavery promoted good institutions or governance. Ethnolinguistic fragmentation, on the other hand, seems endogenous, especially since such fragmentation almost completely disappeared in Europe during the era of growth when a centralized state and market emerged (see, e.g., 
Weber, 1976, Anderson, 1983). Econometrically, the problem with both studies is that their instruments can plausibly have a direct effect on performance. For example, Easterly and Levine (1997) argue that ethnolinguistic fragmentation can affect performance by creating political instability, while Bloom and Sachs (1998) and Gallup, Mellinger, and Sachs (1998) argue for a direct effect of climate on performance. This climate theory of development has a long pedigree; it goes back at least to Montesquieu [1748](1989), who suggested that low income and despotism are more likely in warmer climates. If, indeed, these variables have a direct effect, they are invalid instruments and do not establish that it is institutions that matter. The advantage of our approach is that conditional on the variables we already control for, settler-mortality more than 100 years ago should have no effect on output today, other than through its effect on institutions. Interestingly, our results show that distance from the equator does not have an independent effect on economic performance, so it validates the use of this variable as an instrument in the work by Hall and Jones (1999).

The next section outlines our hypothesis and provides supporting historical evidence. Section 3 presents OLS regressions of GDP per capita on our index of institutions. Section 4 describes our key instrument for institutions, the mortality rates faced by potential settlers at the time of colonization. Section 5 presents our main results. Section 6 investigates the robustness of our results, and Section 7 concludes.

\section{The Hypothesis and Historical Background}

We hypothesize that settler mortality affected settlements; settlements affected early institutions; and early institutions persisted and formed the basis of current institutions. In this section, we discuss and substantiate this hypothesis. The next subsection discusses the link between mortality rates of settlers and settlement decisions, then we discuss differences in colonization policies, and finally, we turn to the causes of institutional persistence.

\subsection{Mortality and Settlements}

There is little doubt that mortality rates were a key determinant of European settlements. Curtin (1964 and 1998) documents how both the British and French press informed the public of the mortality rates in the colonies. For example, early European attempts to settle in West Africa foundered due to high mortality from disease. In the "Province of 
Freedom" European mortality in the first year was 46 percent, in Bulama (April 1792April 1793) there was 61 percent mortality among Europeans, and in the first year of the Sierra Leone Company (1792-1793) 72 percent of the European settlers died. On Mungo Park's Second Expedition (May-November 1805), 87 percent of Europeans died during the overland trip from Gambia to the Niger, and all the Europeans died before completing the expedition. Such rates of mortality were shockingly high for Europeans at the time. ${ }^{4}$

An interesting example of the awareness of the disease environment comes from the Pilgrim fathers. They decided to migrate to the U.S. rather than Guyana because of the very high mortality rates in Guyana (see Crosby, 1986, pp. 143-144). Another example comes from the Beauchamp Committee in 1795 which was set up to decide where to send British convicts, who had previously been sent to the U.S.. One of the leading proposals was the island of Lemane, 400 miles up Gambia river. The committee rejected this possibility precisely because they decided mortality rates would be too high even for the convicts. South-West Africa was also rejected for health reasons. The final decision was to send convicts to Australia.

The eventual expansion of many of the colonies was also related to the living conditions there. In places where the early settlers faced high mortality rates, there would be less incentive for new settlers to come. Curtin (1964), for example, documents how early British expectations for settlement in West Africa were dashed by very high mortality among attempted settlers, about half of whom could be expected to die in the first year.

\subsection{Types OF COLONIZATION AND SETTLEMENTS}

The historical evidence supports both the notion that there was a wide range of different types of colonization and that the presence or absence of European settlers was a key determinant of the form colonialism took. Historians, including Gann and Duignan (1962), Robinson and Gallagher (1961), Denoon (1983), and Cain and Hopkins (1993), have documented the development of "settler colonies", where Europeans settled in large

\footnotetext{
${ }^{4}$ Most mortality in the tropics was from (1) malaria (particularly Plasmodium Falciporum), and (2) yellow fever (with devastating periodic epidemics). In the first half of the nineteenth century there was almost a complete misunderstanding of the nature of malaria - "miasma" from swamps was the prevailing view. Quinine was available but not understood nor used widely. The role of hygiene was also not properly understood. In the second half of the nineteenth century, there developed improved heuristic rules about how to control disease - e.g., an understanding that mortality from malaria is often less at higher altitudes. Low mortality for Europeans in areas with tropical diseases only arrived in the early twentieth century. Throughout the whole nineteenth century, areas without malaria, such as New Zealand or Mauritius, were more healthy than Europe.
} 
numbers, and life was modeled after the home country. Denoon (1983) emphasizes that settler colonies had representative institutions which promoted what the settlers wanted, and what they wanted was freedom and the ability to get rich by engaging in trade. He argues that "there was undeniably something capitalist in the structure of these colonies. Private ownership of land and livestock was well established very early..." (p. 35). ${ }^{5}$

In many cases, when the establishment of European-like institutions did not arise naturally, the settlers were ready to fight for them against the wishes of the home country. Australia is an interesting example here. Most of the early settlers in Australia were ex-convicts, but the land was owned largely by ex-jailors. Initial property rights were therefore unequal, and there was no legal protection against the arbitrary power of landowners. But, the majority of settlers wanted institutions and political rights like those prevailing in England at the time. They demanded jury trials, freedom from arbitrary arrest, and electoral representation. Although the British government resisted at first, the settlers argued that they were British and deserved the same rights as in the home country (see Hughes, 1987). Cain and Hopkins agree with this conclusion and write (1993, p. 237) 'from the late 1840's the British bowed to local pressures and, in line with observed constitutional changes taking place in Britain herself, accepted the idea that, in mature colonies, governors should in future form ministries from the majority elements in elected legislatures." They also suggest that "the enormous boom in public investment after 1870 [in New Zealand]... was an attempt to build up an infrastructure... to maintain high living standards in a country where voters expected politicians actively to promote their economic welfare." (p. 225).

This is in sharp contrast to the colonial experience in Latin America during the 17th and 18th centuries, and in Asia and Africa during the 19th and early 20th centuries. The main objective of the Spanish and the Portuguese colonization was to obtain gold and other valuables from America. For example, soon after the conquest the Spanish crown granted rights to land and labor (the encomienda) and set up a complex mercantilist system of monopolies and trade regulations to extract resources from the colonies (see Lockhart and Schwartz, 1983, and Lang, 1975). ${ }^{6}$ Other European powers were attracted

\footnotetext{
${ }^{5}$ Bates $(1983$, ch. 3) gives a nice example of the influence of settlers on policy. The British colonial government pursued many policies that depressed the price of cocoa, the main produce of the farmers in Ghana. In contrast, the British government supported the prices faced by the commercial cereal farmers in Kenya. Bates shows that this was mainly because in Kenya, but not in Ghana, there were many settler farmers, who exerted considerable pressure on policy.

${ }^{6}$ Migration to Spanish America was limited by the Spanish Crown, in part because of a desire to keep
} 
to colonialism because of the success of this strategy (see for example, Young, 1994, p. $64)$.

European powers developed the slave trade in Africa for the same reasons. Before the mid-nineteenth century, colonial powers were mostly restricted to the African coast and concentrated on monopolizing trade in slaves, gold and other valuable commoditieswitness the names used to descibe West African countries: the Gold Coast, the Ivory Coast. Thereafter, colonial policy was driven in part by an element of superpower rivalry, but mostly by economic motives. Crowder (1968, p. 50), for example, notes "it is significant that Britain's largest colony on the West Coast [Nigeria] should have been the one where her traders were most active and bears out the contention that, for Britain....flag followed trade." 7

Davis and Huttenback (1986, p. 307) conclude that "the colonial Empire provides strong evidence for the belief that government was attuned to the interests of business and willing to divert resources to ends that the business community would have found profitable." They find that before 1885 investment in the British empire had a return 25 percent higher than that on domestic investment, though afterwards the two converged. Roberts (1976, p. 193) summarizes the extent of resource extraction by Britain from Northern Rhodesia by writing "[from]..1930 to 1940 Britain had kept for itself 2,400,000 pounds in taxes from the Copperbelt, while Northern Rhodesia received from Britain only 136,000 pounds in grants for development." Patrick Manning (1982) estimates that between 1905 and 1914, 50 percent of GDP in Dahomey was extracted by the French, and Young (1994, p.125) notes that taxation rates in Tunisia were four times as high as those in metropolitan France.

Probably the most extreme case of extraction was that of King Leopold of Belgium in the Congo. Gann and Duignan (1979, p. 30) argue that following the example of the Dutch in Indonesia, Leopold's philosophy was that "the colonies should be exploited, not by the operation of a market economy, but by state intervention and compulsory cultivation of cash crops to be sold to and distributed by the state at controlled prices." Peemans (1975)

control of the colonists and limit their independence (for example Coatsworth, 1982). This gives further support to our notion that settlers were able to influence the type of institutions set up in the colonies, even against the wishes of the home country government.

${ }^{7}$ Although in almost all cases the main aim was to cement trading privileges, protect economic interests, and obtain profits, the recipients of these profits varied. In the Portuguese case, it was the state, in the Belgian case, it was King Leopold, and in the British case, it was often private enterprises who obtained concessions or monopoly trading rights in Africa (Crowder, 1968, Part III). 
documents the amount of resources extracted from the Belgian Congo and calculates that tax rates on Africans approached 60 percent of their income during the 1920's and 1930's. Jewsiewicki (1983) writes that during the period when Leopold was directly in charge, policy was "based on the violent exploitation of natural and human resources," with a consequent "destruction of economic and social life...[and].. dismemberment of political structures."

In non-settler colonies, there were also few constraints on state power. The colonial powers set-up authoritarian and absolutist states, with the purpose of solidifying their control and facilitating the extraction of resources. Young (1994, p. 101) quotes a French official in Africa as "the European commandant is not posted to observe nature,... He has a mission... to impose regulations, to limit individual liberties...., to collect taxes." Manning (1988, p. 84) summarizes this as: "In Europe the theories of representative democracy won out over the theorists of absolutism... But in Africa, the European conquerors set up absolutist governments, based on reasoning similar to that of Louis XIV."

With a strategy of exploitation in mind, European powers had little incentive to invest in institutions or in infrastructure in Africa. In fact, despite apparently very high rates of return, almost no investment went to Africa (except from South Africa, see Freiden, 1994). The Indian textile industry was similarly rundown heavily, with no investment (e.g., Fieldhouse, 1999). Young writes " [the Belgian companies] brought little capital - a mere 8000 pounds... [to the Congo basin] - and instituted a reign of terror sufficient to provoke an embarrassing public-protest campaign in Britain and the United States at a time when the threshold of toleration for colonial brutality was high." (1994, p. 104).

\subsection{Institutional PeRsistence}

There is a variety of evidence suggesting that the control structures set up in the nonsettler colonies during the colonial era persisted, while there is little doubt that the institutions of law and order and private property established during the early phases of colonialism in Australia, Canada, New Zealand, and the U.S. have been the basis of the current day institutions of these countries. ${ }^{8}$ Young emphasizes that the institutions set up

\footnotetext{
${ }^{8}$ The thesis that institutions persist for a long time goes back at least to Wittfogel (1957), who argued that the control structures set up by the large "hydraulic" empires such as China, Russia, and the Ottoman Empire persisted for more than 500 years to the 20th century. Engerman and Sokoloff (1997), North, Summerhill and Weingast (1998), Coatsworth (1999) and La Porta, Lopez-de-Silanes, Shleifer
} 
by the colonialists persisted long after the colonial regime ended. He writes that (1994, p. 283) "although we commonly described the independent polities as 'new states', in reality they were successors to the colonial regime, inheriting its structures, its quotidian routines and practices, and its more hidden normative theories of governance." Arthur Lewis gives a succinct statement of the issues (1965, pp. 32-33)

"...for most of [the governments of newly independent African states] independence means merely that they have succeeded to the autocracy vacated by British and French civil servants. They model themselves on the arrogant and arbitrary pattern set by Governors and district commissioners."

There are a number of intuitive economic mechanisms that will lead to institutional persistence of this type. Here, we discuss three possibilities.

1. Setting up functioning institutions, which place restrictions on government power and respect property rights, is costly (see, e.g., Acemoglu and Verdier, 1998). If these costs have been sunk by the colonial powers, then it may not pay the elites at independence to switch from this set of institutions to extractive institutions. In contrast, when the new elites inherit extractive institutions, they may not want to incur the costs of introducing better institutions, and may instead prefer to exploit the existing extractive institutions for their own benefits.

An interesting case where functioning institutions proved to be very durable is Mauritius. The French settled in relatively large numbers in Mauritius, and the institutions were less extractive than in many other colonies. ${ }^{9}$ After independence, Paul Berenger and his party Mouvement Militant Mauricien, which were viewed as Communists at the time, came to power. But in contrast to other African regimes, they continued to support property rights and businesses. In fact, they significantly expanded the export processing zones, which were instrumental for the very rapid growth experience of Mauritius (see, for example, Bowman, 1991).

2. The gains to an extractive strategy may depend on the size of the ruling elite. When this elite is small, each member would have a larger share of the revenues, so the

and Vishny $(1998,1999)$ also argue that colonial institutions persisted. Engerman, Mariscal and Sokoloff (1998) provide further evidence supporting this view.

${ }^{9}$ Unfortunately, Mauritius is not in our data set as we do not have information on current institutions. Interestingly, however, Mauritius had very low mortality according to our sources, and is a relatively rich country, with GDP per capita similar to that of Argentina. 
elite may have a greater incentive to be extractive (see Acemoglu and Robinson, 2000). In many cases where European powers set up authoritarian institutions, they delegated the day-to-day running of the state to a small domestic elite. This narrow group often was the one to control the state after independence and favored extractive institutions. Reno (1995), for example, argues that the governments of post-independence Sierra Leone adopted the tactics and institutions of the British colonizers to cement their political power and extract resources from the rest of society. Boone (1992) provides a similar analysis of the evolution of the modern state in Senegal. Perhaps the most extensively studied case is the Congo. Most scholars view the roots of authoritarianism under Mobutu in the colonial state practices (e.g., Callaghy, 1984, or, Turner and Young, 1985, especially p. 43)

The situation in Latin America is similar. Independence of most Latin American countries came in the early nineteenth centuries as domestic elites took advantage of the invasion of Spain by Napoleon to capture the control of the state. But, the only thing that changed was the identity of the recipients of the rents. ${ }^{10}$ The experience of many other Latin American countries is also similar (see Lynch, 1986).

3. Finally, if agents make irreversible investments that are complementary to a particular set of institutions, they will then be more willing to support them, making these institutions persist (see, e.g., Acemoglu, 1995). For example, agents who have invested a lot in human and physical capital will be in favor of spending money to enforce property rights, while those who have less to lose may not be. For example, in the Mauritius example, the presence of a middle-class that had a stake in democracy and the rule of law seems to have been important.

Further evidence for the persistence of extractive state institutions into the independence era is provided by the persistence of the most prominent extractive policies. In Latin America, the full panoply of monopolies and regulations, which had been created by Spain, remained intact for most of the nineteenth century. Forced labor policies persisted and were even intensified or re-introduced with the expansion of export agriculture

\footnotetext{
${ }^{10}$ Coatsworth (1978, p. 95) notes "Mexican independence came through a virtual coup d'état by the colony's Creole elite, carried out largely to separate Mexico from the liberalizing process under way in the Mother country... The principal proponent of these conservative efforts was a limited social group of major landowners and industrialists in the center of the country...who had been the principal beneficiaries in the colony of the crown's interventionism or who, like the large merchant houses of the capital, sought to regain privileges the crown itself had abolished in the reforms of the late Bourbon era."
} 
in the latter part of the nineteenth century. Slavery persisted in Brazil until 1886, and during the sisal boom in Mexico, forced labor was reintroduced and persisted up to the start of the revolution in 1910. Forced labor was also re-introduced in Guatemala and El Salvador to provide labor for coffee growing. In the Guatemalan case, forced labor lasted until the creation of democracy in 1945. Similarly, forced labor was re-instated in many independent African countries, for example, by Mobutu in Zaire.

The situation is similar with other extractive policies. For example, marketing boards, which were used by colonial powers for rent extraction, were a ready made instrument for the newly independent governments to tax agricultural producers (Bates, 1981). The elites who controlled the government had little to gain from abolishing these marketing boards or from setting up more efficient institutions. Very often these boards fitted well with the structure of political power in the post independence era. For example, in Ghana, Nkrumah's support was primarily urban and amongst the Fanti, while the cocoa farmers were inland and Ashanti. So he did not find it beneficial to set up institutions that would restrict his taxation powers, and the marketing board provided a perfect instrument for raising taxes from a group that was not going to support him politically in any case (see Rimmer, 1992). Fieldhouse (1999, p. 96) writes "once these boards came under the control of local politicians they were used to extract surplus from the rural producer, notionally for development purposes, in practice largely for party and personal advantage." He also argues (p. 146) that the fact there were no marketing boards was important in the development experience of Australia.

\section{Institutions and Performance: Ordinary Least Squares Estimates}

\subsection{Data And Descriptive Statistics}

Table 1 provides descriptive statistics for the key variables of interest. The first column is for the whole sample, and column 2 is for our base sample, limited to the 64 countries that were ex-colonies and for which we have settler mortality, institutions and GDP data. The GDP per capita in 1995 is PPP adjusted and is taken from the World Bank's 1999 World Development Indicators CD-Rom (a more detailed discussion of all data sources is provided in the Appendix Table A1). Income (GDP) per capita will be our measure of economic outcome. Since all ex-colonies in our sample had relatively low levels of income 400 years ago, income per capita today is a good measure of long run economic performance. The standard deviation of log per capita income both in the world sample 
and in our basic sample are similar (1.1 in both cases), indicating that the large income differences are present in our sample.

We use a variety of variables to capture institutional differences. Our main variable, reported in the second row, is an index of protection against expropriation. These data are from Political Risk Services (see, e.g., Coplin, 1993), and were first used in the economics and political science literatures by Knack and Keefer (1995). Political Risk Services reports a value between 0 and 10 for each country and year, with 0 corresponding to the highest expropriation risk. We use the average value for each country between 1985 and 1995 (values are missing for many countries before 1985). This protection against expropriation measure is appropriate for our purposes since the focus here is on differences in institutions originating from different types of states and state policies. We expect our notion of extractive state to correspond to a low value of this index, while the tradition of rule of law and well enforced property rights should correspond to high values. ${ }^{11}$ The next row gives an alternative measure, coded from the Polity III data set of Gurr and associates, which is constraints on the executive in 1990 (see Appendix Table A3). This variable is also closely related to state policies and institutions, so is relevant for our purposes. To economize on space, in the text we report only results with the protection against expropriation variable. Results using the constraints on the executive and other measures are reported in the Appendix.

The next three rows give measures of early institutions from the same Gurr data set. The first is a measure of constraints on the executive in 1900 and the second is an index of democracy in 1900. This information is not available for countries that were still colonies in 1900, so we assign these countries the lowest possible score in each index. In the third row, we report an alternative measure, constraints on the executive in the first year of independence, which does not use this assumption, and assigns values for earlier years for many of the Latin America countries and Neo-Europes that were already independent in the 19th-century. The final row gives the fraction of the population of European descent in 1900, which is our measure of European settlement in the colonies, constructed from McEvedy and Jones (1978), Curtin et al (1995) and some additional sources; see Appendix

\footnotetext{
${ }^{11}$ The protection against expropriation variable is most specifically for foreign investment, since Political and Risk Services construct these data for foreign investors. However, as noted by Knack and Keefer (1995), risk of expropriation of foreign and domestic investments are very highly correlated, and risk of expropriation of foreign investment may be more comparable across countries. In any case, all our results hold also with a variety of other institutions and property rights measures (see Tables A1 and A4a, b, c, $\mathrm{d}$, and e).
} 
Table A5).

The remaining columns in Table 1 give descriptive statistics for groups of countries at different quartiles of the settler mortality distribution. This is useful since settler mortality is our instrument for institutions (this variable is described in more detail in the next section).

\subsection{Ordinary Least Squares Regressions}

Table 2 reports Ordinary Least Squares (OLS) regressions of log per capita income on the protection against expropriation variable in a variety of samples. The linear regressions are for the equation

$$
\log y_{i}=\mu+\alpha R_{i}+X_{i}^{\prime} \gamma+\varepsilon_{i}
$$

where $y_{i}$ is income per capita in country $i, R_{i}$ is the protection against expropriation measure, $X_{i}$ is a vector of other covariates, and $\varepsilon_{i}$ is a random error term. The coefficient of interest throughout the paper is $\alpha$, the effect of institutions on income per capita. The first two columns of Table 2 are for the whole world sample, while the second two are for our former colonies sample. Since a priori we have no reason to believe that the relationship between the institutions index and log GDP per capita is linear, in the second and fourth columns, we regress GDP per capita on a set of dummy variables for different quartiles of the distribution of the institutions index. The omitted group is the set of countries in the lowest quartile (with the worst institutions), and three dummies for the other three quartiles are included in the regression. ${ }^{12}$

Column 1 shows that in the whole world sample there is a strong correlation between our measure of institutions and income per capita - recall that the high value of the index means greater protection against expropriation risk. Column 2 indicates that the linear specification is appropriate, as the dummies are ranked in the expected order, and the gap between the various dummies is not very different from that implied by the linear specification. Columns 3-4 show that the impact of the institutions variable on income per capita in our base sample is quite similar to that in the whole world, and Figure 1 shows this relationship diagrammatically. To get a sense of magnitudes, let us compare the 25th and 75th percentiles of the distribution of the institution variable among all ex-colonies. The 25th percentile of the institutional measure in this sample corresponds to a value of

\footnotetext{
${ }^{12}$ More generally, it may therefore be more appropriate to interpret the OLS and IV estimates from linear specifications as local average treatment effects giving the weighted average of the effects at different points (as suggested in Angrist and Imbens, 1995).
} 
5.6, while the 75 th percentile of institutional measure is $7.4 .^{13}$ The estimate in column $3,0.52$, indicates that there should be on average a $94 \log$ point difference between the $\log$ GDPs of the corresponding countries (or approximately a difference equivalent to 154 percent of the GDP of the poorer country). In practice, this GDP gap is 185 log points (approximately 540 percent). Therefore, if the effect estimated in Table 2 were causal, it would imply a fairly large effect of institutions on performance: differences in institutions would account for approximately a quarter of the income per capita differences across countries.

Many social scientists, including Montesquieu [1784](1989), Diamond (1997) and Sachs and coauthors have argued for a direct effect of climate on performance, and Gallup, Mellinger, and Sachs (1998) and Hall and Jones (1999) document the correlation between distance from the equator (latitude) and economic performance. To control for this, in columns 5-8, we add the absolute value of the distance from the equator in degrees (latitude) as a regressor (we follow the literature in using a measure of latitude that is scaled between 0 and 1). This changes the coefficient of the index of institutions little. Latitude itself is also significant and has the sign found by previous studies. The coefficient 1.80 in column 7 indicates that a ten degree (0.10) distance gap from the equator, such as the gap between Mauritania and Algeria, is associated with approximately 18 percent difference in income per capita. In columns 6 and 8, we also add dummies for Africa, Asia and other continents, with America as the omitted group. Although expropriation risk remains significant, the continent dummies are also statistically and quantitatively significant. For example, the coefficient of the Africa dummy in column 8 indicates that in our sample African countries are 90 log points (approximately 145 percent) poorer even after taking the effect of institutions into account.

Overall, the results in Table 2 show a strong correlation between institutions and economic performance. Nevertheless, there are a number of important reasons for not interpreting this relationship as causal. First, our measure refers to current institutions, so it is plausible that rich economies are able to afford, or perhaps prefer, better institutions. Arguably more important than this reverse causality problem, there are many omitted determinants of income differences that will naturally be correlated with institutions. Finally, the measures of institutions are constructed ex post, and the analysts may have had a natural bias in seeing better institutions in richer places. As well as these problems

\footnotetext{
${ }^{13}$ We focus on the inter-quartile range in order to reduce the influence of measurement error.
} 
introducing positive bias in the OLS estimates, the fact that the institutions variable is measured with considerable error creates attenuation and may bias the OLS estimates downwards. All of these problems could be solved if we had an instrument for institutions. Such an instrument must be an important factor in accounting for the institutional variation that we observe, but not have a direct effect on performance. Our discussion in Section 2 suggests that the mortality rates faced by the settlers during the time of colonization is a plausible instrument. The next section will describe the construction of this variable in more detail.

\section{Data on the Mortality of Early Settlers}

Our data on the mortality of European settlers come largely from the work of Philip Curtin. In a series of books and articles over a period of nearly 40 years, Curtin has used a variety of sources to document the mortality of Europeans in new colonies. Systematic military medical record keeping began only after 1815, as an attempt to understand why so many soldiers were dying in some places. The first detailed studies were retrospective and dealt with British forces between 1817 and 1836. The U.S. and French governments quickly adopted similar methods (Curtin 1989, p. 3 and p. 5), and some early data are also available for the Dutch East Indies. By the 1870s, most European countries published regular reports on the health of their soldiers.

The standard measure is annualized deaths per thousand mean strength. This measure reports the death rate among 1,000 soldiers where each death is replaced with a new soldier. Curtin (1989 and 1998) reviews in detail the construction of these estimates for particular places and campaigns, and assesses which data should be considered reliable.

The data can be divided into two parts. Curtin (1989), Death by Migration, deals primarily with the mortality of European troops from 1817 to 1848. At this time modern medicine was still in its infancy, and none of the European militaries yet understood how to design their campaigns so as to reduce mortality. This period is well before the control of malaria and yellow fever was understood, and these were the major causes of death from disease for both soldiers and settlers in places where mortality was high (the third main cause of death was gastrointestinal diseases). These mortality rates can therefore be interpreted as reasonable estimates of settler mortality. They are consistent with substantial evidence from other sources (see, for example, Curtin 1964 and Curtin 1968). 
Curtin (1998), Disease and Empire, adds similar data on the mortality of soldiers in the second half of the nineteenth century. These numbers have to be used with more care, because there was a growing awareness of how to avoid epidemics of the worst tropical diseases, at least during short military campaigns. For example, the campaign in Ethiopia at the end of the nineteenth century had very low mortality rates because it was short and well-managed (see Table A2 and Figure 1). Although the mortality rates from this successful campaign certainly underestimate the mortality rates faced by the settlers in Ethiopia, we did not exclude this country because excluding it would have helped our hypothesis. In all cases, we use the earliest available number for each country, reasoning that this is the best estimate of the mortality that settlers would have faced, at least until the 20th century.

Appendix B reviews in detail how our data are constructed, and describes alternative assumptions that check the robustness of our results. The main gap in the Curtin data is for South America since the Spanish and Portuguese militaries did not keep good records of mortality. However, Gutierrez (1986) used Vatican records to construct estimates for the mortality rates of bishops in Latin America from 1604 to 1876 . Because these data overlap with the Curtin estimates for several countries, we are able to construct a data series for South America (details are in the Appendix). ${ }^{14}$ Curtin (1964) also provides estimates of mortality in naval squadrons for different regions which we can use to generate alternative estimates of mortality in South America. We show in Table 5 that these alternative methods produce remarkably similar results.

\section{Institutions and Performance: Instrumental Variables Results}

\subsection{Determinants of Current Institutions}

Mathematically, our theory can be expressed in the following way. Equation (1), which we rewrite here,

$$
\log y_{i}=\mu+\alpha R_{i}+X_{i}^{\prime} \gamma+\varepsilon_{i},
$$

describes the relationship between current institutions and log GDP. In addition we have

$$
\begin{aligned}
& R_{i}=\lambda_{R}+\beta_{R} C_{i}+X_{i}^{\prime} \gamma_{R}+\nu_{R i} \\
& C_{i}=\lambda_{C}+\beta_{C} S_{i}+X_{i}^{\prime} \gamma_{C}+\nu_{\mathrm{C} i}
\end{aligned}
$$

\footnotetext{
${ }^{14}$ Combining data from a variety of sources will surely introduce measurement error in our estimates of settler mortality. Nevertheless, since we are using settler mortality as an instrument, this measurement error does not lead to inconsistent estimates of the effect of institutions on performance.
} 


$$
S_{i}=\lambda_{S}+\beta_{S} \log M_{i}+X_{i}^{\prime} \gamma_{S}+\nu_{\mathrm{S} i}
$$

where $R$ is the measure of current institutions (protection against expropriation between 1985 and 1995), $C$ is our measure of early (circa 1900) institutions, $S$ is the measure of European settlements in the colony (fraction of the population with European decent in 1900 ), and $M$ is mortality rates faced by settlers. $X$ is a vector of covariates that affect all variables.

The simplest identification strategy is to use $\log M_{i}$ directly as an instrument for $R_{i}$ in equation (1). This identification strategy will be valid as long as $\log M_{i}$ is uncorrelated with $\varepsilon_{i}$ - even if $C_{i}$ and $S_{i}$ were correlated with $\varepsilon_{i}$. For example, if Europeans were more likely to migrate to places with better resources and soil quality, and if resources and soil quality still had an effect on income, there would be a correlation between $S_{i}$ and $\varepsilon_{i}$. This would make European migration patterns an invalid instrument for current institutions. Nevertheless, our identification strategy of using $\log M_{i}$ directly as an instrument would be valid. We start with this identification strategy, and then use the other equations to derive overidentifying restrictions.

Figure 2 illustrates the relationship between the (potential) settler mortality rates and the index of institutions. We use the logarithm of the settler mortality rates, since there are no theoretical reasons to prefer the level as a determinant of institutions rather than the log, and using the log ensures that the extreme African mortality rates do not play a disproportionate role. As it happens, there is an almost linear relationship between the $\log$ of the mortality rate and our measure of institutions. ${ }^{15}$

In Table 3, we document that this relationship works through the channels hypothesized in Section 2. In particular, we present OLS regressions of equations (2), (3), and (4). In the top panel, we regress the protection against expropriation variable on the other variables. Column 1 uses constraints faced by the executive in 1900 as the regressor, and shows a close association between early institutions and institutions today. For example, past institutions alone explain 21 percent of the variation in the index of current institutions. The second column adds the latitude variable, with little effect on the estimate. Columns 3 and 4 use the democracy index, and confirm the results using the constraints on the executive variable.

Both constraints on the executive and democracy indices assign low scores to countries

\footnotetext{
${ }^{15}$ Note that Gambia has a surprisingly good score for protection against expropriation risk. We do not exclude this country, since doing so would help our hypothesis.
} 
that were colonies in 1900, and do not use the earliest post-independence information for Latin American countries and Neo-Europes. In columns 5 and 6, we adopt an alternative approach and use the constraints on the executive in the first year of independence (and also control separately for time since independence). The results are similar, and indicate that early institutions persist.

Columns 7 and 8 show the association between protection against expropriation and European settlements. The fraction of Europeans in 1900 alone explains approximately 29 percent of the variation in our institutions variable today. Columns 9 and 10 show the relationship between the protection against expropriation variable and the mortality rates faced by settlers. This specification will be the first-stage for our main 2SLS estimates. These regressions show that settler mortality alone explains 26 percent of the differences in institutions we observe today.

Panel B of Table 3 provides evidence in support of the hypothesis that early institutions were shaped, at least in part, by settlements, and that settlements were affected by mortality. Columns 1-2 and 5-6 relate our measure of constraint on the executive and democracy in 1900 to the measure of European settlements in 1900 (fraction of the population of European decent). Columns 3-4 and 7-8 relate the same variables to mortality rates of settlers. These regressions show that settlement patterns explain over 50 percent of the variation in early institutions. Finally, columns 9 and 10 show the relationship between settlements and mortality rates.

Overall, Table 3 provides support for our hypothesis that mortality rates faced by potential settlers affected settlement behavior, and that settlement behavior affected the type of institutions that the colonialists brought to the country, and finally that early institutions persisted to the present. We next use settler mortality directly as an instrument for current institutions, and look at the impact of current institutions on performance.

\subsection{Institutions and Economic Performance}

The basic results are presented in Table 4. The main equation is (1). We treat the protection against expropriation variable, $R_{i}$, as endogenous, and model it as

$$
R_{i}=\zeta+\beta \log M_{i}+X_{i}^{\prime} \delta+v_{i}
$$

where $M_{i}$ is our settler mortality rate. The exclusion restriction is that this variable does not appear in (1). So we estimate equations (1) and (5) jointly with two stage least squares (2SLS), using $\log M_{i}$ as an instrument for $R_{i}$. 
Panel A of Table 4 reports 2SLS estimates of the coefficient of interest, $\alpha$ from equation (1) and Panel B gives the corresponding first-stages. ${ }^{16}$ Column 1 displays the strong first-stage relationship between (log) settler mortality and current institutions in our base sample, also shown in Table 3. The corresponding 2SLS estimate of the impact of institutions on income per capita is 0.95 This estimate is highly significant with a standard error of 0.16, and in fact larger than the OLS estimates reported in Table 2. This suggests that measurement error in the institutions variables that creates attenuation bias is likely to be more important than reverse causality and omitted variables biases.

To evaluate the quantitative significance of these estimates, we again compare the 25th and 75 th percentiles of the distribution of the protection against expropriation variable among all ex-colonies. The baseline 2SLS estimate of 0.95 implies that there should be a $171 \log$ point (450 percent) difference between the average GDPs of the countries at the 25th and 75th percentiles of the distribution of protection against expropriation, as compared to the $185 \log$ points (540 percent) difference in the data. Therefore, these estimates suggest that over three-quarters of the income per capita differences across countries is due to differences in institutions. Figure 3 plots the predicted values of income per capita from our baseline regression, which includes only the institutions index as a regressor, against actual income per capita for the countries in our sample (as well as the 45 degree line). Most observations are close to the 45 degree line, which confirms the explanatory power of our regression. ${ }^{17}$

Column 2 shows that adding latitude does not change the relationship; the institutions coefficient is now 0.98 with a standard error of $0.22{ }^{18}$ Remarkably, the latitude variable now has the "wrong" sign and is insignificant. This result suggests that many previous studies may have found latitude to be a significant determinant of economic performance because it is correlated with institutions (or with their exogenous component caused by early colonial experience).

Columns 3 and 4 document that our results are not driven by the Neo-Europes. When we exclude the U.S., Canada, Australia, and New Zealand, the estimates remain highly

\footnotetext{
${ }^{16}$ We have also run these regressions with standard errors corrected for possible clustering of the mortality rates assigned from the same disease environment. This clustering has little effect on the standard errors, and does not change our results.

${ }^{17}$ The cloud of points in this graph indicates a slope somewhat smaller than the 45 degree line, so our 2SLS estimates may be underpredicting the income level in the countries with the worst institutions.

${ }^{18}$ In 2SLS estimation, all covariates that are included in the second stage, such as latitude, are also included in the first stage. When these first stage effects are of no major significance for our argument, we do not report them in the tables to save space.
} 
significant, and in fact increase a little. For example, the coefficient for institutions is now 1.29 (s.e. $=0.37$ ) without the latitude control, and $1.2($ s.e. $=0.35)$ when we control for latitude.

Columns 5 and 6 show that the result is also robust to dropping all the African countries from our sample. The estimates without Africa are somewhat smaller, but also more precise. For example, the coefficient for institutions is 0.61 (s.e. $=0.11$ ) without the latitude control, and 0.59 (s.e.=0.12) when we control for latitude.

In Columns 7 and 8, we add continent dummies to the regressions (for Africa, Asia and other, with America as the omitted group). The addition of these dummies does not change the estimated effect of institutions, and the dummies are jointly insignificant at the 5 percent level, though the dummy for Asia is significantly different from that of America. The fact that the African dummy is insignificant suggests that the reason why African countries are poorer is not due to cultural or geographic factors, but mostly accounted for by the existence of worse institutions in Africa.

In Appendix Table A4a, b, c, d, and e, we repeat the same exercise using a variety of alternative measures of institutions. These are constraints on the executive from the Polity III dataset, an index of law and order tradition from Political Risk Services, a measure of property rights from the Heritage Foundation, a measure of rule of law from the Fraser Institute, and the efficiency of the judiciary from Business International (see Tables A1 and A4 for more details). The results and the magnitudes are very similar to those reported in Table 4. Furthermore, in Appendix Table A3, we also report very similar results with 1970 values for the constraints on the executive and income per capita in 1970, which show that the relationship between institutional measures and income per capita holds across time periods. ${ }^{19}$

We should note at this point that if we limit the sample to African countries only, the first stage relationship using the protection against expropriation variable becomes considerably weaker, and the 2SLS effect of institutions is no longer significant. The 2SLS effect of institutions continue to be significant when we use the constraint on the

\footnotetext{
${ }^{19}$ The presence of alternative measures of institutions also enables us to ascertain whether the difference between OLS and 2SLS estimates could really be due to measurement error in the institution variable. If we use the constraints on the executive measure as an instrument for the protection against expropriation measure, this would solve the measurement error, but not the endogeneity problem. This exercise leads to an estimate of the effect of protection against expropriation equal to .88 (with standard error .16), which suggests that measurement error in the institutions variables is very important, and can explain the whole difference between the OLS and 2SLS estimates.
} 
executive variable or Fraser Institute's rule of law variable (and not with other measures). Therefore, we conclude that the relationship between settler mortality and institutions is weaker within Africa.

Overall, the results in Table 4 show a large effect of institutions on economic performance. In the rest of the paper, we investigate the robustness of these results.

\section{Robustness}

\subsection{Alternative samples}

In Table 5, we investigate the robustness of our results in different subsamples. In Table 4 we reported results in samples which differed by region. Here our objective is to see whether the results are robust to varying degrees of data quality and different methods of constructing the mortality estimates. In columns 1 and 2, we only use data from Curtin (1989), Death by Migration, which is for 17 countries and refers always to pre-1840 data. In this smaller sample, we find an even stronger relationship both in the first stage and the second stage. The 2SLS estimate of the effect of institutions on income per capita is 1.0 (s.e. $=0.25$ ) without controlling for latitude, and 1.1 (s.e. $=0.33$ ) when latitude is included in the regression (compared to 0.95 and 0.98 in Table 4).

In columns 3 and 4, we add data from the second book by Curtin (1998), Disease and Empire, for the earliest date available for each country. This increases the sample to 31 countries, and reduces both the estimate and the standard error a little; the results are now much more similar to those reported in Table 4 . In columns 5 and 6 , we use other information (described in detail in the Appendix), to assign mortality rates to neighboring countries with the same disease environment. This increases the sample to 44, and changes the estimates little. In columns 7 and 8, we add data for Latin America, but this time from naval stations instead of bishops. The results are identical to those obtained in Table 4. In columns 9 and 10, we use an alternative ("conservative") coding of the African data. In particular, rather than using African estimates from small samples, we assign mortality rates to areas that shared the same disease environment. For example, the same number from Sierra Leone is applied to Benin, Cote d'Ivoire, Ghana, Guinea, Nigeria, Togo, and the number from French Soudan is assigned to Mali and Niger. This leads to estimates very similar to our baseline results. Finally, in columns 11 and 12, we report regressions using mortality rates relative to home country, which again yield very similar effects. Overall we conclude that the results hold in different samples with 
varying degrees of data reliability.

\subsection{Additional CONTROLS}

The validity of our 2SLS results in Table 4 depends on the assumption that settler mortality in the past has no direct effect on current economic performance. Although this presumption appears reasonable, here we substantiate it further by directly controlling for many of the variables that could plausibly be correlated with both settler mortality and economic outcomes. Overall, we find that our results change remarkably little with the inclusion of these variables, and many variables emphasized in previous work become insignificant once the effect of institutions is controlled for.

La Porta, Lopez-de-Silanes, Shleifer and Vishny (1999) argue for the importance of colonial origin (main colonizer) as a determinant of current institutions. The identity of the colonial power could also matter because it might have an effect through culture, as argued by Landes (1998). In column 1, we add dummies for the identity of the main colonizer (for Belgium, Germany, the Netherlands, Italy, France, Spain, Portugal, with Britain as the omitted group). ${ }^{20}$ The top panel gives the 2SLS estimates, the second panel gives the first stage, and the bottom panel gives the corresponding OLS coefficient on the protection against expropriation variable. The even numbered columns add latitude. With or without latitude, the effect of institutions on income per capita is robust to the inclusion of these dummies. Interestingly, the first-stage estimates show that these dummies are jointly insignificant at the 15 percent level (i.e., a p-value over .15), when the effect of mortality rates faced by the colonizers is controlled for (even though the dummy for being a Belgian colony, which captures the Congo, is significantly negative). These results therefore show little evidence for a major influence of the identity of the colonizer on institutions once we control for the effect of the mortality rates faced by colonialists. They therefore contrast with a common perception that the British former colonies perform better. ${ }^{21}$ The reason why British colonies appear to perform better in

\footnotetext{
${ }^{20}$ In the table, we only report the coefficients on the Belgian, French and Spanish dummies to save space, but the other dummies are also included in the estimation.

${ }^{21} 2$ SLS estimates show that the identity of the colonizer does have an effect on income per capita (i.e., an effect not working through institutions). In particular, Belgian and Spanish ex-colonies do better than expected relative to their institutions. This is because Belgian and Spanish ex-colonies have substantially worse institutions, but the performance of these countries is not as bad as would be expected on the basis of their institutions alone. The Belgian and Spanish dummies therefore take on positive values in the 2SLS estimatation to compensate for this. For example, in the case of Belgian colonies, the first-stage effect is -2.9 , which multiplied with the coefficient of 1.1 on institutions, implies that Belgian
} 
other studies seems to be that Britain colonized places where settlements were possible, and this made British colonies inherit better institutions (in our sample too, ex-British colonies have considerably better institutions, so if we drop the log mortality variable from the regression, the British dummy has a significant and large positive effect on institutions).

Hayek and (1960) and LaPorta, Lopez-de-Silanes, Shleifer and Vishny (1999) also emphasize the importance of legal origin. In columns 3 and 4, we control for legal origin. In our sample, all countries have either French or British legal origins, so we simply add a dummy for French legal origin (many countries that are not French colonies nonetheless have French legal origin). Once again, our estimate of the effect of institutions on income per capita is unaffected. This time, however, we find that French legal origin is associated with worse institutions, even when we control for the mortality rates faced by the settlers. ${ }^{22}$

An argument dating back to Max Weber views religion as a key determinant of economic performance. To control for this, in columns 5 and 6 , we add the fraction of the populations that are Catholic, Muslim, and of other religions, with Protestants as the ommitted group. In the table we report the significance level (p-value) of the corresponding F-statistic for these dummies as well as the 2SLS estimate of the effect of institutions. Religion appears highly correlated with income per capita (in particular, higher fractions of Catholics and Protestants are associated with greater income per capita), but the 2SLS estimate of the effect of institutions hardly changes. Finally, column 7 adds all the variables in this table simultaneously. Again, these controls have very little effect on our main estimate.

Another concern is that settler mortality is correlated with climate and current disease environment. Our instrument may therefore be picking up the direct effect of these variables. In Table 7, we add a set of temperature and humidity variables. These are: average, minimum and maximum monthly high temperatures, and minimum and maximum monthly low temperatures, and morning minimum and maximum humidity, and

ex-colonies should be approximately 320 log points poorer. The positive coefficient of 2.4 in the secondstage somewhat compensates for this, and leaves a net effect of $240-320=-80 \log$ points (122 percent) for Belgian colonies - still a very large effect!

${ }^{22}$ In the second stage estimation, when the effect of institutions on performance is taken into account, the French legal origin dummy is positive. This is again for the reasons outlined in footnote 21 . The net effect of having French legal origin is not as bad as one would expect on the basis of the effect of French legal origins on institutions, but is still substantially negative, $-90+23=-67 \log$ points (approximately 95 percent). 
afternoon minimum and maximum humidity. In the table we report joint significance levels for these variables (all data from Parker, 1997). Again, they have little effect on our estimates.

Sachs and a series of coauthors have argued for the importance of malaria in explaining African poverty (see, for example, Bloom and Sachs, 1998, Gallup and Sachs, 1998, and Gallup et al., 1998). Since malaria was one of the main causes of settler mortality, our estimate may be capturing some of the direct effects of malaria. We are skeptical of this argument since the prevalence of malaria is highly endogenous; it is the poorer countries with worse institutions that have been unable to eradicate malaria. ${ }^{23}$ Moreover, it is hard to imagine how malaria could have such a large effect on economic performance. Although Sachs and coauthors argue that this works through poor health, high mortality and absenteeism, most people who live in high malaria areas have developed some immunity to the disease - if they survive to the age of five, they can fall ill periodically but malaria is not fatal to them (see Curtin, 1998, or Bruce-Chwatt, 1980). We might therefore expect that malaria should not have a very large effect on economic performance (though, obviously, it will have very high social costs). In contrast, for Europeans, or anyone else who has not been exposed to malaria as a very young child, malaria is fatal, ${ }^{24}$ making variations in malaria a key determinant of whether Europeans could settle in a colony.

In any case, controlling for malaria does not change our results. We do this in the second part of Table 7 by controlling for the fraction of the population who live in an area where falciporum malaria is endemic in 1994 (as constructed and used by Gallup et al, 1998). In Appendix C, we show that the inclusion of an endogenous variable positively correlated with income or institutions will bias the coefficient on institutions downwards. Since the prevalence of malaria in 1994 is highly endogenous, controlling for it directly will therefore underestimate the effect of institutions on performance. As a result, the coefficient on protection against expropriation is estimated to be somewhat smaller in

\footnotetext{
${ }^{23}$ For example, the U.S. eliminated malaria from the Panama Canal zone, and Australia eliminated it from Queensland (see Crosby, 1986, pp.141-142). Even in Africa, there are very successful campaign against malaria, including those in Algeria and that conducted by the Rio-Tinto Zinc mining company in Zambia (then Northern Rhodesia).

${ }^{24}$ Some types of malaria are quite local. It is therefore quite possible for a person to have immunity to the local version of malaria, but to be highly vulnerable to malaria a short distance away. This is probably one explanation why Africans had such high mortality when they were forced to move by colonial powers. For example, African labor on the Congo-Ocean railroad had mortality of 240 per thousand at its peak, and 100 per thousand on average (Curtin, et al., 1995).
} 
Table 7, .76 instead of .95 as in Table 4. Nevertheless, it remains highly significant with a standard error of .27, while malaria itself is highly insignificant. ${ }^{25}$ Hence, we conclude that the effect of settler mortality on performance is not through its correlation with the current disease environment, but likely through its effect on institutions.

A related concern is that in colonies where Europeans settled, the current population consists of a higher fraction of Europeans. One might be worried that we are capturing the direct effect of having more Europeans. To control for this we add the fraction of the population of European descent in columns 7 and 8 of Table 7 (constructed from McEvedy and Jones (1978), Curtin et al (1995) and some additional sources; see Appendix Table A5). Interestingly, this variable is insignificant, while the effect of institutions remains highly significant, with a coefficient of .87 and a standard error of .21. In column 9 of Table 7, we add all these variables, for temperature, humidity, malaria, and European descent, together, and the estimate of the effect of protection against expropriation on income per capita is affected little.

Finally, in Table 8 we add a variety of controls for other potential determinants of income per capita. These include a measure of ethnolinguistic fragmentation, measures of soil quality and natural resources, and whether the country is landlocked (see the Table A1 in the Appendix for definitions). For example, in column 1 where we include ethnolinguistic fragmentation, the coefficient of protection against expropriation is 0.74 $($ s.e. $=0.13)$, which is only slightly smaller than our baseline estimate. Since ethnolinguistic fragmentation is likely to be endogenous with respect to development (i.e., ethnolinguistic fragmentation tends to disappear during periods of growth and formation of centralized markets, see Weber, 1976, or Andersen, 1983) and is correlated with settler mortality, the estimate of 0.74 likely understates the effect of institutions on income (see Appendix C). The estimates also change relatively little when other controls are added. We therefore conclude that the effect of variations in institutions caused by early colonial experience on income is robust, and likely captures the causal effect of institutions and government policies on economic well-being.

\footnotetext{
${ }^{25}$ Malaria is marginally significant in column 9 when we control for latitude, fraction of European descent, and eight temperature and humidity variables. Nevertheless, all of these variables, or any subset of them with malaria, are always jointly insignificant. For example, the F-test that all of these variables are insignificant has a p-value of .17.
} 


\subsection{OVERIDENTIFICATION TESTS}

We can also investigate the validity of our approach by using overidentification tests. Recall that according to our theory, settler mortality affected settlements; settlements affected early institutions; and early institutions affected current institutions. Mathematically, we expressed these links by equations (2), (3), and (4). We can test whether any of these variables, $C, S$, and $M$, has a direct effect on income per capita, $\log y$, by using measures of $C$ and $S$ as additional instruments.

The overidentification test will reject if:

1. the equation of interest (1) does not have a constant coefficient, i.e., $\log y_{i}=\mu+$ $\alpha_{i} R_{i}+\varepsilon_{i}$, or

2. $C$ or $S$ has a direct effect on income per capita, $\log y_{i}$ (i.e., either $S$ or $C$ is correlated with $\varepsilon_{i}$ ), or

3. settler mortality, $M$, has an effect on $\log y_{i}$ that works through another variable, such as culture.

The overidentifying restrictions implied by our approach are never rejected. This implies that, subject to the caveats related to the power of the overidentification tests, we can rule out all three of the above possibilities. This gives us additional confidence that settler mortality is a valid instrument and that we are estimating the effect of institutions on current performance with our instrumental variable strategy (i.e., not capturing the effect of some other variable correlated with settler mortality).

The results of the overidentification tests, and related results, are reported in Table 9. In the top panel, Panel A, we report the 2SLS estimates of the effect of protection against expropriation on GDP per capita using a variety of instruments other than mortality rates, while Panel B gives the corresponding first-stages. These estimates are always quite close to those reported in Table 4. For example, in column 1, we use European settlements in 1900 as the only instrument for institutions. This results in an estimated effect of .90 (with standard error .13), as compared to our baseline estimate of .95. The other columns add latitude, and use other instruments such as constraint on the executive in 1900 and in the first year of independence, and democracy in 1900.

Panel D reports an easy-to-interpret version of the overidentification test. It adds the $\log$ of mortality as an exogenous regressor. If mortality rates faced by settlers had 
a direct effect on income per capita, we would expect this variable to come in negative and significant. In all cases, it is small and statistically insignificant in all cases. For example, in column 1, log mortality has a coefficient of -.06 (with standard error .07). This confirms that the impact of mortality rates faced by settlers likely works through their effect on institutions.

Finally, for completeness, in Panel $\mathrm{C}$ we report the p-value from the appropriate $\chi^{2}$ overidentification test. This tests whether the 2SLS coefficients estimated with the instruments indicated in Panels A and B versus the coefficients estimated using (log) settler mortality in addition to the other instruments are significantly different (e.g., in the first column, the coefficients using European settlements alone are compared to estimates using European settlements and log mortality as instruments). We never reject the hypothesis that they are equal; so these results also show no evidence that mortality rates faced by settlers have a direct effect - or an effect working through a variable other than institutions - on income per capita.

\section{Concluding Remarks}

Many economists and social scientists believe that differences in institutions and state policies are at the root of large differences in income per capita across countries. There is little agreement, however, about what determines institutions and the attitude of governments towards economic progress. This makes it difficult to isolate exogenous sources of variation in institutions to estimate their effect on performance. In this paper we argued that differences in colonial experience could be a viable source of exogenous differences in institutions.

Our argument rests on the following premises. Europeans adopted very different colonization strategies, with different associated institutions. In one extreme, as in the case of the U.S., Australia and New Zealand, they went and settled in the colonies and set-up institutions that enforced the rule of law and encouraged investment. In the other extreme, as in the Congo or the Gold Coast, they set up extractive states with the intention of transferring resources rapidly to the metropole. The slave trade is perhaps the most extreme example of this behavior. These sets of institutions were very detrimental to investment and economic progress. Which colonization strategy was adopted was, at least in part, determined by the feasibility of European settlement. In places where Europeans faced very high mortality rates, they could not go and settle, and they were more likely 
to set up extractive states. Finally, we argue that these early institutions persisted to the present. Determinants of whether Europeans could go and settle in the colonies, therefore, have an important effect on institutions today. We exploit these differences as a source of exogenous variation to estimate the influence of institutions on economic performance.

We document these hypotheses in the data by showing a high correlation between mortality rates faced by soldiers, bishops, and sailors in the colonies and European settlements; between European settlements and early measures of institutions; and between early institutions and institutions today. We estimate large effects of institutions on income per capita using this source of variation. Our estimates imply that differences in institutions account for roughly three-quarters of the differences in income per capita. We also document that this relationship is not driven by outliers, and is robust to controlling for climate, current disease environment, religion, natural resources, and current race composition.

It is useful to point out that our findings do not imply that institutions today are predetermined by colonial policies and cannot be changed. We emphasize colonial experience as one of the many factors affecting institutions. Since mortality rates faced by settlers are arguably exogenous, they are useful as an instrument to isolate the effect of institutions on performance. In fact, our reading is that these results suggest substantial income gains from improving institutions in poor countries.

There are many questions that our analysis does not address. Institutions are treated to some degree as a "black-box": our results indicate that reducing expropriation risk (or increasing other measures of propoerty rights enforcement) would result in significant gains in income per capita, but do not point out what type of concrete steps would lead to an improvement in these institutions. Institutional features, such as expropriation risk, property rights enforcement or rule of law, should probably be interpreted as an equilibrium outcome, related to some more fundamental "institutions", e.g., presidential vs. parliamentary system, or the presence of common law, etc., which can be changed directly. A more detailed analysis of the effect of more fundamental institutions on property rights and expropriation risk is an important area for future study. 


\section{Appendix A:Data Sources}

Appendix Table A1 shows the complete list of variables that we use, together with their definitions and sources.

\section{Appendix B:Construction of Settler Mortality Data}

Appendix Table A2 reports our estimates for settler mortality in each country. The first column of mortality estimates shows data from Curtin (1989) for countries located in the exact place for which we have a mortality estimate from the first half of the nineteenth century. These data are used in the first two columns of Table 5 .

We have direct estimates of settler mortality for Algeria (1831-38), Canada (181736), Guyana (1819-36), Jamaica (1817-36), Malta (1817-36), Mauritius (1818-36), New Zealand (1846-55), Senegal (1819-38), and Sierra Leone (1819-36). We also have comparable estimates for Britain (1830-36) and France (1820-22 and 1824-26). In some cases there has been a simple change of name, but the country is the same geographically. We can therefore use the estimate of settler mortality from Ceylon (1817-36) for Sri Lanka, from Coastal Burma (1829-38) for Myanmar, from Cape Colony (1818-36) for South Africa, and from the Windwards and Leewards islands (1817-36) for Barbados and for Trinidad and Tobago. It is also reasonable to use the mortality estimate from Bengal (1830-38) for Bangladesh, from the Dutch East Indies (1819-28) for Indonesia, and from the Straits Settlements (1829-38) for Malaysia and Singapore. Note that there is a large variation in mortality between the Straits Settlements and Dutch East Indies, even though these areas are quite close geographically. This is because there exists substantial variation in disease environment, particularly for malaria, even in neighboring areas. For example, Curtin (1998) explains in detail the substantial variation in malaria risk just within Madagascar at the end of the nineteenth century. Micro-climate, particularly the pattern of rainfall and the precise vegetation, play a significant role in determining the risk of malaria. See Curtin (1989) for further discussion.

For large countries where we have more than one regional estimate, we need to make a choice. For the U.S. we use the estimate for the Northern United States (1829-38). For India we use the estimate from Madras (1829-38); this is lower than for Bengal but higher than for Bombay. None of our regression results are significantly affected if we use alternative regional data for these countries.

The second column of mortality estimates in Appendix Table A2 adds data from 
Curtin (1998), which covers the second half of the nineteenth century. Whenever Curtin provides more than one estimate, we use the earliest available number for each country. We have mortality data directly from Mexico in 1862-63 and Tunisia in 1881. As we note in the text, data from the second half of the nineteenth century have to be used with care, because there were improvements in the practice of military medicine around the mid-nineteenth century, but most of this would not have helped to reduce the mortality of civilian settlers. For example, the British campaigns of 1882 in Egypt, 1867-68 in Ethiopia and the 1884-85 Nile expedition had low mortality because the army hurried in and out with reasonable preventive health measures. We use the estimate for the Magdala campaign of 1867-68 for Ethiopia (Curtin 1998, p. 44) and the post-campaign, 1882, mortality estimate for Egypt (the Egyptian 1882 campaign mortality was about half the mortality in the immediate post-campaign period, see Curtin 1998, p. 158). For Sudan, we use the death rate from 1885 at Suakin (on the coast). This was 88.2 per 1000 mean strength, mostly from typhoid. The very high mortality from disease in Madagascar in 1895 is a reasonable estimate of what settlers would have expected because this was not a particularly well-organized campaign (Curtin 1998, p. 188).

In the Mali campaign during 1878, the French expeditionary force lost 49 percent of its Europeans to disease, particularly to yellow fever, in less than two months (Curtin 1998, p. 89). This is equivalent to an annual rate of 2,940 per 1000 mean strength. This is high relative to what would have been expected in most years, but quite typical of periods when there was an outbreak of yellow fever. We do not know the true extent of yellow fever in West Africa, precisely because it was a major disincentive to settle and Europeans generally stayed away from the most dangerous places. Yellow fever was thought less frequent on the Gold Coast (Ghana) than elsewhere in West Africa, but there were recorded outbreaks in 1852, 1857, 1859, and 1862 (Curtin 1998, p. 65). In April-May 1873, an outbreak of yellow fever in the Niger delta killed two-thirds of the Europeans there. This was a quite typical death rate (see Curtin 1998, Table 4.1, p. 79, for the death rate of Europeans in Senegal yellow fever epidemics). The case fatality for nonimmune adults before quinine was 25-75 percent from malaria and 75 percent for yellow fever.

In Gambia, from May 1825 to December 1826, fever killed 279 British soldiers out of a force that was seldom over 120 and often only 40 strong (Curtin 1998, p. 10). Assuming a mean strength of 120 gives total deaths per 1,000 of 2,300, which is high but not extraordinary for that time and place. This converts into a mortality rate of 120 per 
month, or 1,470 per year.

The second column of mortality estimates in Appendix Table A2 assigns a settler mortality number to a modern country if the country name today is the same as in Curtin (1998). In Haut-Senegal (Niger), in 1880-83 there was a death rate of 400 per 1000 mean strength (Curtin 1998, p. 85). In 1841, European mortality on a Niger expedition (in modern Nigeria) was 167 per 1000 per month, equivalent to 2,004 per 1000 mean strength per year (Curtin 1998, p. 89). In a period of several months, 82 percent of the Europeans died from malaria. At least in this time and place, it was almost impossible for a person to go for an entire year without receiving at least one infective mosquito bite.

This second column also assigns the same number to countries that were previously part of one country. For example, Burkina Fasu, Central African Federation, Chad, French Congo, and Mauritania were part of French Soudan. The estimate for Vietnam is from Cochin China.

The third column of mortality estimates assigns a mortality number to a country if it neighbors a country for which we have data and has the same disease environment. On the Gold Coast (approximately southern Ghana today) in the period 1824-26, European troops died from disease at a rate of 668 per 1000 per annum (Curtin 1998, p. 18). Cote d'Ivoire and Togo had the same disease environment and we use the same estimate. Angola, Cameroon, Rwanda, and Uganda receive the estimate from French Soudan, and Guinea is from the Sierra Leone estimate. The estimate for Morocco is from Algeria and Pakistan is from Bombay. Surinam is a neighor of French Guinea, for which we have a direct estimate for the period 1819-36. The estimate for Kong is from the 1860 China Field Force.

The third column of mortality estimates also assigns a number to several countries for which we do not have mortality data for Europeans but we do have data for Africans who moved into this country from a different disease environment, so they did not have a built-up immunity to local malaria. As Curtin (1968) shows, in all situations where we have adequate data, mortality of Africans from a disease environment is lower than but comparable to European mortality. We can have a reasonable lower bound on European mortality in Kenya of 145 per 1000 (Curtin et al 1995, p. 491) and in Congo of 240 per 1000 (Curtin et al 1995, p. 463).

The fourth column of Appendix Table A2 provides the data that we use in most of our analysis. We use the data from the third column and add settler mortality estimates for a 
few countries that are close by and have the same disease environment as places for which we have direct data. We use the New Zealand estimate for Australia and the Windwards and Leewards estimate for the Bahamas, Jamaica for Haiti and the Dominican Republic (information from Gutierrez 1986 indicates that these were similar disease environments).

We also use a combination of the Gutierrez (1986) and Curtin (1989) numbers to construct estimates for South America. Gutierrez calculates the mortality of bishops aged 40-49 for three disease environments in the Caribbean, Central and South America: 10 (low), 11 (medium), and 23 (high) per 1000. We assume the ratio between bishop mortality levels in different disease environments was the same as the ratio between soldier mortality. We also assume that the type of disease environment (low, medium or high) was the same for bishops and soldiers. We then use Gutierrez's ratios with the Curtin (1998) estimate of mortality of 71 per 1000 for Mexico 1862-63 (a low mortality region in Gutierrez's classification), to generate estimates of mortality for Central and South America.

Note that the estimates we obtain would be virtually the same if we used the Curtin (1989) estimate for Jamaica as the benchmark (a high disease environment by Gutierrez's classification). The implied mortality in Jamaica, using the Gutierrez data, would be 163.3. The direct estimate for mortality in Jamaica is 130 per 1000 in 1817-36 (Curtin, 1989). Running our regressions using data that takes Jamaica as the base for applying the Gutierrez's ratios actually strengthens our results.

Gutierrez provides considerable detail on the location of low, medium, and high mortality areas for bishops. High mortality regions are the Caribbean, low lying parts of Central America, and tropical South America. This includes Nicaragua, and Panama. Medium mortality locations are Costa Rica, El Salvador, Honduras, Paraguay, and Venezuela. Low mortality locations are Bolivia, Brazil, Colombia, Ecuador, Guatemala, Peru, and Uruguay. ${ }^{26}$ Some of these countries have a large variation in their disease environment, even for a relatively small country. We know, for example, that the Colombian coast was very unhealthy to Europeans. Mortality in the British siege of Cartegena in 1742 was very high - the force was there for only two months, but deaths from disease were between $2 / 3$ and $3 / 4$ of the army (Curtin, 1989, p. 2). But most Europeans who went

\footnotetext{
${ }^{26}$ It is particularly difficult to assign an estimate to Brazil because we do not know the precise difference in mortality between the North-East, where much of the early settlement was attempted, and more southern locations that later attracted population. We have adopted a low mortality estimate as this is less favorable to our hypothesis.
} 
to Colombia were able to settle at a higher altitude, e.g., in Bogota, where the disease environment was much more favorable. It therefore seems reasonable to follow Gutierrez's classification of disease environments, as the bishops tended to live where European population was concentrated.

The last column of Appendix Table A2 uses an alternative source to calculate mortality in Latin America. Average annual mortality, 1825-1845, from disease in the British naval forces off West Africa was 54.4 per thousand (Curtin, 1964, p. 486). Comparable mortality from disease at other naval stations over the same period was 7.7 in South America, 9.3 in the Mediteranean, 9.8 in the Home Station, 15.1 in the East Indies, and 18.1 in the West Indies. The level of mortality from disease for British sailors was lower than for British soldiers in all locations, but it is reasonable to assume that the ratio of mortalities between the various regions was approximately the same.

This change of data does not affect the numbers much. For example, Argentina and Chile move from a mortality of 71 per 1000 (using the data on bishops) to 68.9 (using the data on naval forces). Table 5 reports regression results using alternative classifications, with little effect on our findings.

Our baseline estimates in column 4 imply very high mortality rates in a number of West African countries. Some of these estimates come from relatively small samples of soldiers. We take comfort in the fact that our results are not affected when all African countries are dropped from the sample. Nevertheless, as another check on our results, we constructed a more conservative series of mortality estimates, which is reported in column 6. This series uses only Curtin estimates from long sample periods, and assigns those to neighboring countries with the same disease environment. In particular, this series assigns the mortality estimate from Sierra Leone to Cote d'Ivoire, Ghana, Nigeria, and Togo, and assigns the estimate from French Soudan to the French Congo, Kenya, Mali, Niger, Tanzania, and Zaire. We also use an alternative, lower estimate of mortality for Madagascar (from Curtin, 1998). Table 5 shows that this different series leads to very similar results to our baseline series.

There still remain several significant gaps. Most important, we do not have any reliable estimates for much of Southern Africa, including Lesotho, Namibia, Swaziland, Zimbabwe, Zambia, Malawi, Mozambique, or Botswana. We also do not have any reasonable estimates for Eritrea, the Philippines, Cape Verde or Comoros. Liberia and Thailand were not colonies and are not included in our study. 
Appendix Table A2 reports mortality data for several countries for which we do not have data on institutions or GDP per capita (PPP basis): Barbados, Central African Federation, Chad, Mauritania, Myanmar, Mauritius, Rwanda, and Surinam. Qualitatively, the GDP per capita in these countries is quite consistent with the settler mortality numbers and our regression results.

Finally, note that these estimates of mortality for soldiers are similar to the more fragmentary evidence available on civilian settlers. For example, we know that early European attempts to settle in West Africa foundered due to high mortality from disease (Curtin, 1964). In the "Province of Freedom" European mortality in the first year was 46 percent, in Bulama (April 1792-April 1793) there was 61 percent mortality among Europeans, and in the first year of the Sierra Leone Company (1792-1793) 72 percent of the European settlers died. 


\section{Appendix C:Bias in The Effect of Institutions When Other Endogenous Variables Are InCluded}

To simplify notation, suppose that $R_{i}$ is exogenous, and another variable that is endogenous, $z_{i}$, such as prevalence of malaria or ethnolinguistic fragmentation, is added to the regression. Then, the simultaneous equations model becomes

$$
\begin{aligned}
Y_{i} & =\mu_{0}+\alpha R_{i}+\pi z_{i}+\varepsilon_{i} \\
z_{i} & =\mu_{1}+\phi Y_{i}+\eta_{i},
\end{aligned}
$$

where $Y_{i}=\log y_{i}$. We presume that $\alpha \geq 0, \phi<0$, and $\pi<0$, which implies that we interpret $z_{i}$ as a negative influence on income. Moreover, this naturally implies that $\operatorname{cov}\left(\eta_{i}, \varepsilon_{i}\right)<0$ and $\operatorname{cov}\left(z_{i}, R_{i}\right)<0$, that is the factor $z_{i}$ is likely to be negatively correlated with positive influences on income.

Standard arguments imply that

$$
\operatorname{plim} \widehat{\alpha}=\alpha+\frac{\operatorname{cov}\left(\widetilde{R}_{i}, \varepsilon_{i}\right)}{\operatorname{var}\left(\widetilde{R}_{i}\right)}=\alpha-\kappa \cdot \frac{\operatorname{cov}\left(z_{i}, \varepsilon_{i}\right)}{\operatorname{var}\left(\widetilde{R}_{i}\right)},
$$

where $\kappa$ and are $\widetilde{R}_{i}$ are the coefficient and the residual from the auxiliary equation,

$$
R_{i}=\kappa_{0}+\kappa z_{i}+\widetilde{R}_{i},
$$

and so

$$
\kappa=\frac{\operatorname{cov}\left(z_{i}, R_{i}\right)}{\operatorname{var}\left(z_{i}\right)}<0
$$

which is negative due to the fact that $\operatorname{cov}\left(R_{i}, z_{i}\right)<0$. The reduced form for $z_{i}$ is:

$$
z_{i}=\frac{1}{1-\phi \pi}\left((\mu+\phi \pi)+\phi \alpha R_{i}+\phi \varepsilon_{i}+\eta_{i}\right) .
$$

We impose the regularity condition $\phi \cdot \pi<1$, so that an increase in the disturbance to the $z$-equation, $\eta_{i}$, actually increases $z_{i}$. Now using this reduced form, we can write

$$
\operatorname{plim} \widehat{\alpha}=\alpha-\kappa \cdot \frac{\operatorname{cov}\left(z_{i}, \varepsilon_{i}\right)}{\operatorname{var}\left(\widetilde{R}_{i}\right)}=\alpha-\kappa \cdot \frac{\left(\sigma_{\varepsilon \eta}+\phi \sigma_{\varepsilon}^{2}\right)}{(1-\phi \pi) \cdot \operatorname{var}\left(\widetilde{R}_{i}\right)}
$$

where $\sigma_{\varepsilon}^{2}$ is the variance of $\varepsilon$, and $\sigma_{\varepsilon \eta}$ is the covariance of $\varepsilon$ and $\eta$.

Substituting for $\kappa$ in (8), we obtain:

$$
\operatorname{plim} \widehat{\alpha}=\alpha-\frac{\left(\sigma_{\varepsilon \eta}+\phi \sigma_{\varepsilon}^{2}\right)}{(1-\phi \pi) \cdot \operatorname{var}\left(\widetilde{R}_{i}\right)} \cdot \frac{\operatorname{cov}\left(z_{i}, R_{i}\right)}{\operatorname{var}\left(z_{i}\right)}
$$

Recall that $\phi<0, \sigma_{\varepsilon \eta}<0$, and $\operatorname{cov}\left(z_{i}, R_{i}\right)<0$. Therefore, plim $\widehat{\alpha}<\alpha$, and when we control for the endogenous variable $z_{i}$, the coefficient on our institution variable will be biased downwards. 


\section{REFERENCES}

Acemoglu, Daron (1995) "Reward Structures and the Allocation of Talent," European Economic Review, 39, 17-38.

Acemoglu, Daron and James A. Robinson (2000) "Political Origins of Poverty and Prosperity," Unpublished Working Paper, MIT.

Acemoglu, Daron and Thierry Verdier (1998). "Property Rights, Corruption and the Allocation of Talent: A General Equilibrium Approach." Economic Journal, 108, 1381-1403.

Alesina, Alberto and Roberto Perotti (1996) "Income Distribution, Political Instability and Investment," European Economic Review, 40, 1203-1225.

Anderson, Benedict (1983) Imagined Communities, Verso, London.

Angrist, Joshua and Guido Imbens (1995) "Two-Stage Least Squares Estimates of Average Causal Response in Models with Variable Treatment Intensity," Journal of the American Statistical Association,

Bates, Robert H. (1981) Markets and States in Tropical Africa, University of California Press, Berkeley CA.

Bates, Robert H. (1983) Essays on the Political Economy of Rural Africa, Cambridge University Press, Cambridge.

Bertocchi, Graziella and Fabio Canova (1996) "Did Colonization Matter for Growth? An Empirical Exploration into the Historical Causes of Africa's Underdevelopment," CEPR Discussion Paper \#1444.

Besley, Timothy (1995) "Property Rights and Investment Incentives: Theory and Evidence from Ghana," Journal of Political Economy, 103, 903-937.

Bloom, David E. and Jeffrey D. Sachs (1998) "Geography, Demography, and Economic Growth in Africa," Brookings Papers on Economic Activity, 1998:2, 207-295.

Boone, Catherine (1992) Merchant Capital and the Roots of State Power in Senegal, 1930-1985, Cambridge University Press, New York NY.

Bowman, Larry W (1991) Mauritius: democracy and development in the Indian Ocean, Boulder, Colo., Westview Press.

Bruce-Chwatt, Leonard J. (1980) Essential Malariology, London.

Cain, Philip J. and Anthony G. Hopkins (1993) British Imperialism: Innovation and Expansion 1688-1914, Longman, New York. 
Callaghy, Thomas M. (1984) The State-Society Struggle: Zaire in Comparative Perspective, Columbia University Press, New York NY.

Chabal Patrick (1986) Political Domination in Africa, Cambridge University Press, Cambridge.

Chazan Noami et al (1988) Poilitcs and Society in Contemporary Africa, Boulder, Colo..

Coatsworth, John H. (1978) "Obstacles to Economic Growth in Nineteenth-Century Mexico," American Historical Review, 83, 80-100.

Coatsworth, John H. (1982) "The Limits of Colonial Absolutism: Mexico in the Eighteenth Century," in Karen Spalding ed. Essays in the Political, Economic and Social History of Latin America, University of Delaware Press, Newark DL.

Coatsworth, John H. (1999) "Economic and Institutional Trajectories in Nineteenth Century Latin America," in John H. Coatsworth and Alan M. Taylor eds. Latin America and the World Economy since 1800, Harvard University Press, Cambridge MA.

Coplin, William D., Michael K. O'Leary, Tom Sealy (1991) A Business Guide to Political Risk for International Decisions, 2nd edition, Political Risk Services, Syracuse, NY.

Crosby, Alfred (1986) Ecological Imperialism: The Biological Expansion of Europe 900-1900, Cambridge University Press, New York NY.

Crowder, Michael (1968) West Africa under Colonial Rule, Northwestern University Press, Evanston IL.

Curtin, Philip D. (1964) The Image of Africa, University of Wisconsin Press, Madison.

Curtin, Philip D. (1968) "Epidemiology and the Slave Trade," Political Science Quarterly, 83:181-216.

Curtin, Philip D. (1989) Death by Migration: Europe's Encounter with the Tropical World in the Nineteenth Century, Cambridge University Press, New York NY.

Curtin, Philip D. (1998) Disease and Empire: The Health of European Troops in the Conquest of Africa, Cambridge University Press, New York NY.

Curtin, Philip D., Steven Feierman, Leonard Thompson, and Jan Vansina (1995) African History: From Earliest Times to Independence, Longman, London and New York, Second Edition.

Davis, Lance E. and Robert A. Huttenback (1987) Mammon and the Pursuit of 
Empire: The Political Economy of British Imperialism, 1860-1912, Cambridge University Press, Cambridge UK.

Denoon, Donald (1983) Settler Capitalism: The Dynamics of Dependent Development in the Southern Hemisphere, Clarendon Press, Oxford UK.

Diamond, Jared M. (1997) Guns Germs and Steel: The Fate of Human Societies, W.W. Norton \& Co., New York NY.

Easterly, William and Ross Levine (1997) "Africa's Growth Tragedy: Policies and Ethnic Divisions," Quarterly Journal of Economics, 1203-1250.

Engerman, Stanley L. and Kenneth L. Sokoloff (1997) "Factor Endowments, Institutions, and Differential Paths of Growth among New World Economies," in S.H. Haber ed. How Latin America Fell Behind, Stanford University Press, Stanford CA.

Engerman, Stanley L., Elisa Mariscal and Kenneth L. Sokoloff (1998) "Schooling, Suffrage, and the Persistence of Inequality in the Americas, 1800-1945," Unpublished Paper, Department of Economics, UCLA.

Fieldhouse, David K. (1999) The West and the Third World, Blackwell, Oxford UK.

Freiden, Jeffery (1994) "International Investment and Colonial Control: A New Interpretation," International Organization, 48, 559-593.

Gallup, John L., Andrew D. Mellinger and Jeffrey D. Sachs (1998) "Geography and Economic Development," NBER Working Paper \#6849.

Gallup, John L. and Jeffrey D. Sachs (1998) "The Economic Burden of Malaria," Unpublished paper, Harvard Center for International Development, October.

Gann, Lewis. H. and Peter Duignan (1962) White Settlers in Tropical Africa, Penguin, Baltimore MD.

Gann, Lewis. H. and Peter Duignan (1979) The Rulers of Belgian Africa, Princeton University Press, Princeton NJ.

Grier, Robin M (1999) "Colonial Legacies and Economic Growth" Public Choice Vol. 98 (3-4), 317-35

Gutierrez, Hector (1986) "La Mortalite des Eveques Latino-Americains aux XVIIe et XVII Siecles," Annales de Demographie Historique, 29-39.

Gurr, Ted Robert (1997) "Polity II: Political Structures and Regime Change, 1800-1986," Unpublished paper, University of Colorado, Boulder.

Gwartney, James and Robert Lawson (1997) Economic Freedom of the World 
1997, The Fraser Institute.

Hall, Robert E. and Charles I. Jones (1999) "Why Do Some Countries Produce so Much More Output per Worker than Others?," Quarterly Journal of Economics, CXIV, 83-116.

Hayek, Frederich A. von (1960) The Constitution of Liberty University of Chicago Press,

Herbst, Jeffrey (2000) States and Power in Africa, Princeton University Press, Princeton.

Holmes, Kim R., Bryan T. Johnson, and Melanie Kirkpatrick (1997) 1997 Index of Economic Freedom, The Heritage Foundation and The Wall Street Journal, Washington DC and New York.

Hughes, Robert (1987) The Fatal Shore, Collins Harvill, London UK.

Jones, Eric L. (1981) The European Miracle: Environments, Economies and Geopolitics in the History of Europe and Asia, Cambridge University Press, Cambridge UK.

Jewsiewicki, B. (1983) "Rural Society and the Belgian Colonial Economy," in D. Birmingham and P.M. Martin eds. The History of Central Africa, Volume II, Longman, New York.

Johnson, Simon, John McMillan and Christopher Woodruff (1999) "Property Rights and Finance," Unpublished working paper, MIT and UC San Diego.

Knack, Steven and Philip Keefer (1995) "Institutions and Economic Performance: Cross-Country Tests Using Alternative Measures," Economics and Politics, 7, $207-227$.

Landes, David S. (1998) The Wealth and Poverty of Nations: Why Some Are So Rich and Some So Poor, W.W. Norton \& Co., New York.

Lang, James (1975) Conquest and Commerce: Spain and England in the Americas, Academic Press, New York NY.

La Porta, Rafael, Florencio Lopez-de-Silanes, Andrei Shleifer and Robert W. Vishny (1998). "Law and Finance," Journal of Political Economy, 106, 1113-55.

La Porta, Rafael, Florencio Lopez-de-Silanes, Andrei Shleifer and Robert W. Vishny (1999) "The Quality of Government," Journal of Law, Economics and Organization, 15, 222-279.

Lewis, W. Arthur (1965) Politics in West Africa, Oxford University Press, New York NY. 
Lipset, Seymour M. (1994) "The Social Requisites of Democracy Revisited," American Sociological Review, 59, 1-22.

Lockhart, James and Stuart B. Schwartz (1983) Early Latin America, Cambridge University Press, New York NY.

Lynch, John (1986) The Spanish American Revolutions, 1808-1826, W.W. Norton \& Co. New York NY.

Manning, Patrick (1982) Slavery, Colonialism, and Economic Growth in Dahomey, 1640-1980, Cambridge University Press, New York NY.

Manning, Patrick (1988) Francophone Sub-Saharan Africa, 1880-1995, Cambridge University Press, New York NY.

Mauro, Paulo (1995) "Corruption and Growth," Quarterly Journal of Economics, CX, 681-712.

Mazingo, Christopher (1999) "Effects of Property Rights on Economic Activity: Lessons from the Stolypin Land Reform," Unpublished Paper, Department of Economics, MIT.

McEvedy, Colin and Richard Jones (1975), Atlas of World Population History, Facts on File, New York.

McNeill, William H. (1976) Plagues and Peoples, Anchor Press, Garden City NJ.

Montesquieu, Charles de Secondat [1748] (1989) The Spirit of the Laws, Cambridge University Press, New York NY.

North, Douglas C. (1981) Structure and Change in Economic History, W.W. Norton \& Co., New York.

North, Douglass C., William Summerhill and Barry Weingast (1998) "Order, Disorder and Economic Change: Latin America vs North America," Unpublished Manuscript, Hoover Institution, Stanford University.

North, D.C. and R.P. Thomas (1973) The Rise of the Western World: A New Economic History, Cambridge University Press, Cambridge UK.

Parker, Philip M. (1997) National Cultures of the World: A Statistical Reference, Cross-Cultural Statistical Encyclopedia of the World, Volume 4, Greenwood Press, Westport, CT.

Peemans, Jean-Philippe (1975) "Capital Accumulation in the Congo under Colonialism: The Role of the State," in Lewis. H. Gann and Peter Duignan eds. Colonialism in Africa 1870-1960, Volume 4 The Economics of Colonialism, Hoover Institution Press, 
Stanford CA.

Reno, William (1995) Corruption and State Politics in Sierra Leone, Cambridge University Press, New York NY.

Rimmer, Douglas (1992) Staying Poor: Ghana's Political Economy 1950-1990, Pergamon Press, Oxford UK.

Roberts Andrew (1976) A History of Zambia, Heinemann, London.

Robinson, Ronald E. and John Gallagher (1961) Africa and the Victorians: The Official Mind of Imperialism, MacMillan, London.

Rodrik, Dani (1999) "Where has all the Growth Gone?" forthcoming in the Journal of Economic Growth.

Turner, Thomas and Crawford Young (1985) The Rise and Decline of the Zairian State, University of Wisconsin Press, Madison WI.

Weber, Eugen J. (1976) Peasants into Frenchmen, Stanford University Press, Stanford CA.

Wittfogel, Karl A. (1957) Oriental Despotism: A Comparative Study of Total Power, Yale University Press, New Haven CT.

Young, Crawford (1994) The African Colonial State in Comparative Perspective, Yale University Press, New Haven CT. 
Table 1

Descriptive Statistics

\begin{tabular}{|c|c|c|c|c|c|c|}
\hline & \multirow[t]{2}{*}{$\begin{array}{l}\text { Whole } \\
\text { World }\end{array}$} & \multirow[t]{2}{*}{$\begin{array}{c}\text { Base } \\
\text { Sample }\end{array}$} & \multicolumn{4}{|c|}{ By Quartiles of Mortality } \\
\hline & & & (1) & $(2)$ & (3) & (4) \\
\hline Log GDP per capita (PPP) in 1995 & $\begin{array}{c}8.3 \\
(1.1)\end{array}$ & $\begin{array}{l}8.05 \\
(1.1)\end{array}$ & 8.9 & 8.4 & 7.73 & 7.2 \\
\hline $\begin{array}{l}\text { Average Protection Against } \\
\text { Expropriation Risk, 1985-1995 }\end{array}$ & $\begin{array}{c}7 \\
(1.8)\end{array}$ & $\begin{array}{c}6.5 \\
(1.5)\end{array}$ & 7.9 & 6.5 & 6 & 5.9 \\
\hline Constraint on Executive in 1990 & $\begin{array}{l}3.6 \\
(2.3)\end{array}$ & $\begin{array}{c}4 \\
(2.3)\end{array}$ & 5.3 & 5.1 & 3.3 & 2.3 \\
\hline Constraint on Executive in 1900 & $\begin{array}{c}1.9 \\
(1.8)\end{array}$ & $\begin{array}{c}2.3 \\
(2.1)\end{array}$ & 3.7 & 3.4 & 1.1 & 1 \\
\hline $\begin{array}{l}\text { Constraint on Executive in First } \\
\text { Year of Independence }\end{array}$ & $\begin{array}{c}3.6 \\
(2.4)\end{array}$ & $\begin{array}{c}3.3 \\
(2.4)\end{array}$ & 4.8 & 2.4 & 3.1 & 3.4 \\
\hline Democracy in 1900 & $\begin{array}{l}1.1 \\
(2.6)\end{array}$ & $\begin{array}{c}1.6 \\
(3.0)\end{array}$ & 3.9 & 2.8 & 0.19 & 0 \\
\hline European Settlements in 1900 & $\begin{array}{l}0.31 \\
(0.4)\end{array}$ & $\begin{array}{l}0.16 \\
(0.3)\end{array}$ & 0.32 & 0.26 & 0.08 & 0.005 \\
\hline Log Mortality & n.a. & $\begin{array}{c}4.7 \\
(1.1)\end{array}$ & 3 & 4.3 & 4.9 & 6.3 \\
\hline Number of Observations & 163 & 64 & 14 & 18 & 17 & 15 \\
\hline
\end{tabular}

Standard deviations are in parentheses. Mortality is potential settler mortality, in deaths per annum per 1000 people, sources and methods are described in Appendix Table 2. Quartiles of mortality are for our base sample of 64 observations. These are: (1) less than 65.4 ; (2) greater than or equal to 65.4 and less than 78.1 ; (3) great than or equal to 78.1 and less than 280; (4) greater than or equal to 280.

Average Protection Against Expropriation is measured on a scale from 0 to 10, where a higher score indicates greater protection against risk of expropriation of investment by government, from Political Risk Services, with128 observations in the Whole World sample and 64 observations in our Base Sample. Constraint on Executive in 1990, 1900, and First Year of Independence is measured from 1 to 7, where a higher score indicates more constitutional limits on arbitrary actions by the executive in that year, from the Polity III data set, with 89 observations in the Whole World sample and 59 observations in our Base Sample. First Year of Independence is the first year that the country appears in the Polity III data set. Democracy in 1900 is measured on a scale from 0 to 10, where a higher score indicates more democracy, from the Polity III data set, with 89 observations in the Whole World sample and 59 observations in our Base Sample.

European settlements in 1900 is the fraction of the population in 1900 that was European or of European descent constructed from McEvedy and Jones (1978), Curtin et al (1995) and some additional sources (see Appendix Table A5), with 155 observations in the Whole World sample and 63 observations in the Base Sample. Constraint on executive in 1900 and democracy in 1900 are set equal to 1 (the lowest score) for countries that were colonies in that year. See Appendix Table A1 for more detailed variable definitions and sources. 
Table 2

OLS Regressions

\begin{tabular}{|c|c|c|c|c|c|c|c|c|}
\hline & $\begin{array}{c}\text { Whole } \\
\text { World } \\
(1) \\
\end{array}$ & $\begin{array}{c}\text { Whole } \\
\text { World } \\
(2) \\
\end{array}$ & $\begin{array}{c}\text { Base } \\
\text { Sample } \\
(3) \\
\end{array}$ & $\begin{array}{c}\text { Base } \\
\text { Sample } \\
(4)\end{array}$ & $\begin{array}{c}\text { Whole } \\
\text { World } \\
(5) \\
\end{array}$ & $\begin{array}{c}\text { Whole } \\
\text { World } \\
(6) \\
\end{array}$ & $\begin{array}{c}\text { Base } \\
\text { Sample } \\
(7) \\
\end{array}$ & $\begin{array}{c}\text { Base } \\
\text { Sample } \\
(8) \\
\end{array}$ \\
\hline $\begin{array}{l}\text { Average Protection Against } \\
\text { Expropriation Risk, 1985-1995 }\end{array}$ & $\begin{array}{l}0.54 \\
(0.04)\end{array}$ & & $\begin{array}{l}0.52 \\
(0.06)\end{array}$ & & $\begin{array}{l}0.46 \\
(0.06)\end{array}$ & $\begin{array}{l}0.42 \\
(0.05)\end{array}$ & $\begin{array}{l}0.46 \\
(0.07)\end{array}$ & $\begin{array}{l}0.40 \\
(0.06)\end{array}$ \\
\hline $\begin{array}{l}\text { Dummy for anti-expropriation in } \\
\text { in second quartile }\end{array}$ & dex & $\begin{array}{l}0.27 \\
(0.22)\end{array}$ & & $\begin{array}{l}0.52 \\
(0.25)\end{array}$ & & & & \\
\hline $\begin{array}{l}\text { Dummy for anti-expropriation in } \\
\text { in third quartile }\end{array}$ & dex & $\begin{array}{l}1.50 \\
(0.22)\end{array}$ & & $\begin{array}{l}1.50 \\
(0.26)\end{array}$ & & & & \\
\hline $\begin{array}{l}\text { Dummy for anti-expropriation in } \\
\text { in fourth quartile }\end{array}$ & dex & $\begin{array}{l}2.20 \\
(0.21)\end{array}$ & & $\begin{array}{l}2.00 \\
(0.35)\end{array}$ & & & & \\
\hline Latitude & & & & & $\begin{array}{l}1.00 \\
(0.49)\end{array}$ & $\begin{array}{l}0.50 \\
(0.51)\end{array}$ & $\begin{array}{l}1.80 \\
(0.72)\end{array}$ & $\begin{array}{l}1.10 \\
(0.63)\end{array}$ \\
\hline Asia Dummy & & & & & & $\begin{array}{l}-0.67 \\
(0.19)\end{array}$ & & $\begin{array}{l}-0.66 \\
(0.23)\end{array}$ \\
\hline Africa Dummy & & & & & & $\begin{array}{l}-1.00 \\
(0.16)\end{array}$ & & $\begin{array}{l}-0.90 \\
(0.17)\end{array}$ \\
\hline "Other" Continent Dummy & & & & & & $\begin{array}{l}-0.28 \\
(0.21)\end{array}$ & & $\begin{array}{l}-0.04 \\
(0.32)\end{array}$ \\
\hline Adjusted R-Squared & 0.61 & 0.58 & 0.52 & 0.43 & 0.62 & 0.72 & 0.55 & 0.68 \\
\hline $\mathrm{N}$ & 110 & 110 & 64 & 64 & 110 & 110 & 64 & 64 \\
\hline
\end{tabular}

Dependent Variable: Log GDP per capita (PPP basis) in 1995, current prices, (from the World Bank's World Development Indicators 1999). Average protection against expropriation risk is measured on a scale from 0 to 10 , where a higher score means more protection against expropriation, averaged over 1985 to 1995, from Political Risk Services. Standard errors are in parentheses. In regressions including dummies for the anti-expropriation index, the dummy for the first quartile --i.e., with highest risk of expropriation-- is the omitted category. In regressions with continent dummies, the dummy for America is omitted. See Appendix Table A1 for more detailed variable definitions and sources. 
Table 3

Determinants of Institutions

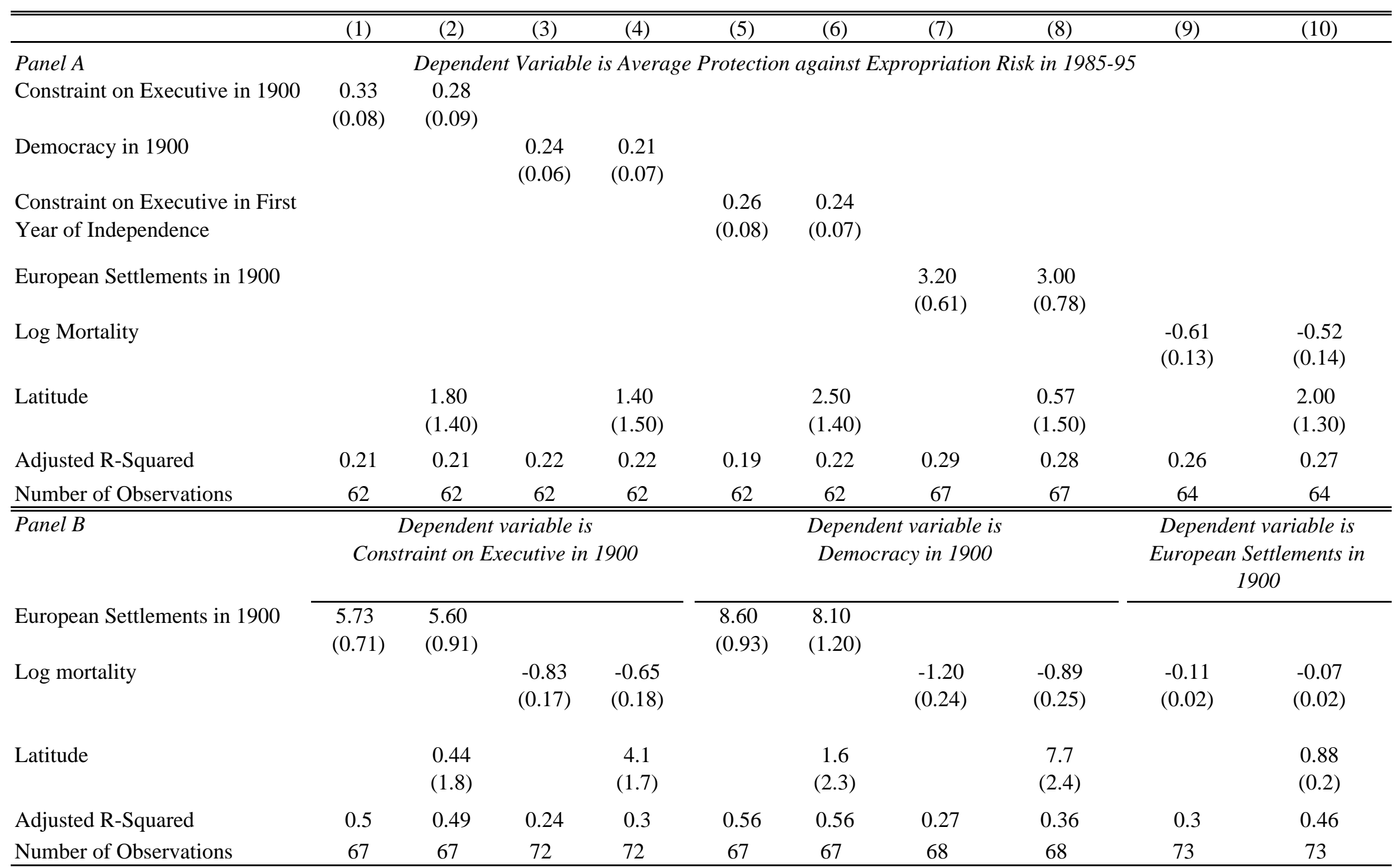

All regressions are OLS, using base sample. Standard errors are in parentheses. Regressions with constraint on executive in first year of independence also include years since independence as a regressor. Average protection against expropriation risk is a on scale from 0 to 10 , where a higher score means more protection against expropriation of private investment by government, averaged over 1985 to 1995 . Constraint on Executive in 1900 is on a scale, from 1 to 7 , with a higher score indicating more constraints. Democracy in 1990 is on a scale from 0 to 10, with a higher score indicating more democracy. European settlements is percent of population that was European or of European descent in 1900.

See Appendix Table A1 for more detailed variable definitions and sources. 
Table 4

IV Regressions of log GDP per capita

\begin{tabular}{|c|c|c|c|c|c|c|c|c|}
\hline & $\begin{array}{c}\text { Base } \\
\text { Sample } \\
(1)\end{array}$ & $\begin{array}{c}\text { Base } \\
\text { Sample } \\
(2)\end{array}$ & $\begin{array}{c}\text { Base } \\
\text { Sample } \\
\text { without } \\
\text { neo- } \\
\text { Europes } \\
(3)\end{array}$ & $\begin{array}{c}\text { Base } \\
\text { Sample } \\
\text { without } \\
\text { neo- } \\
\text { Europes } \\
(4)\end{array}$ & $\begin{array}{c}\text { Base } \\
\text { Sample } \\
\text { without } \\
\text { Africa } \\
\quad(5)\end{array}$ & $\begin{array}{c}\text { Base } \\
\text { Sample } \\
\text { without } \\
\text { Africa } \\
\quad(6)\end{array}$ & $\begin{array}{c}\text { Base } \\
\text { Sample } \\
\text { with } \\
\text { Continent } \\
\text { Dummies } \\
\quad(7)\end{array}$ & $\begin{array}{c}\text { Base } \\
\text { Sample } \\
\text { with } \\
\text { Continent } \\
\text { Dummies } \\
\text { (8) }\end{array}$ \\
\hline \multicolumn{9}{|c|}{ Panel A: Two Stage Least Squares } \\
\hline $\begin{array}{l}\text { Average Protection Against } \\
\text { Expropriation Risk 1985-1995 }\end{array}$ & $\begin{array}{l}0.95 \\
(0.16)\end{array}$ & $\begin{array}{c}0.98 \\
(0.22)\end{array}$ & $\begin{array}{c}1.29 \\
(0.37)\end{array}$ & $\begin{array}{c}1.2 \\
(0.35)\end{array}$ & $\begin{array}{c}0.61 \\
(0.11)\end{array}$ & $\begin{array}{c}0.59 \\
(0.12)\end{array}$ & $\begin{array}{c}0.93 \\
(0.24)\end{array}$ & $\begin{array}{l}1.00 \\
(0.3)\end{array}$ \\
\hline Latitude & & $\begin{array}{c}-0.4 \\
(1.30)\end{array}$ & & $\begin{array}{c}1.3 \\
(1.50)\end{array}$ & & $\begin{array}{c}0.22 \\
(0.89)\end{array}$ & & $\begin{array}{l}-0.77 \\
(1.5)\end{array}$ \\
\hline Asia Dummy & & & & & & & $\begin{array}{l}-0.96 \\
(0.37)\end{array}$ & $\begin{array}{l}-1.00 \\
(0.44)\end{array}$ \\
\hline Africa Dummy & & & & & & & $\begin{array}{l}-0.47 \\
(0.33)\end{array}$ & $\begin{array}{l}-0.45 \\
(0.37)\end{array}$ \\
\hline "Other" Continent Dummy & & & & & & & $\begin{array}{l}-0.67 \\
(0.6)\end{array}$ & $\begin{array}{l}-0.68 \\
(0.6)\end{array}$ \\
\hline
\end{tabular}

Panel B: First-Stage for Average Protection against Expropriation Risk in 1985-95

Log Mortality

$\begin{array}{cccccccc}-0.61 & -0.52 & -0.39 & -0.4 & -1.2 & -1.1 & -0.48 & -0.4 \\ (0.13) & (0.14) & (0.13) & (0.14) & (0.20) & (0.24) & (0.16) & (0.17)\end{array}$

Latitude

2.00

$-0.15$

1.9

(1.30)

(1.50)

(1.40)

Asia Dummy

Africa Dummy

(n)

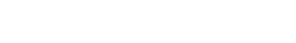

$0.3 \quad-0.4$

(0.5) (0.5)

$-0.26 \quad-0.24$

"Other" Continent Dummy

$(0.41) \quad(0.41)$

$1-0.87$

(0.68) (0.68)

Adjusted R-Squared

0.26

0.27

0.12

0.1

0.45

0.54

0.26

0.27

Average Protection Against

$0.52 \quad 0.46$

Panel C: Ordinary Least Squares

Expropriation Risk 1985-1995

(0.06) (0.06)

0.48

$0.46 \quad 0.48$

0.45

0.43

0.4

Number of Observations

$64 \quad 64$

60

(0.08)

(0.07)

(0.08)

(0.06)

(0.06)

"Average Protection Against Expropriation Risk 1985-95" is measured on a scale from 0 to 10, where a higher score means more protection against risk of expropriation of investment by the government, from Political Risk Services (see Appendix Table A1 for more detail). Panel A reports the two stage least squares estimates with log GDP per capita (PPP basis) in 1995 as the dependent variable and instrumenting for protection against expropriation risk using log settler mortality; Panel B reports the corresponding first stage. Panel C reports the OLS coefficient from regressing log GDP per capita on protection against expropriation risk, with the other control variables indicated in that column (full results not reported to save space). Standard errors are in parentheses. In regressions with continent dummies, the dummy for America is omitted. 
Table 5

IV Regressions of log GDP per capita with Alternative Samples

\begin{tabular}{|c|c|c|c|c|c|c|c|c|c|c|c|c|}
\hline & $\begin{array}{c}\text { Pre-1855 } \\
\text { data } \\
(1)\end{array}$ & $\begin{array}{c}\text { Pre-1855 } \\
\text { data } \\
(2)\end{array}$ & $\begin{array}{c}\text { Earliest } \\
\text { available } \\
\text { data } \\
\text { (3) }\end{array}$ & $\begin{array}{c}\text { Earliest } \\
\text { available } \\
\text { data } \\
(4)\end{array}$ & $\begin{array}{c}\text { Including } \\
\text { neighbors } \\
\text { with same } \\
\text { disease } \\
\text { environment } \\
(5) \\
\end{array}$ & $\begin{array}{c}\text { Including } \\
\text { neighbors } \\
\text { with same } \\
\text { disease } \\
\text { environment } \\
(6) \\
\end{array}$ & $\begin{array}{c}\text { Including } \\
\text { Latin } \\
\text { America } \\
\text { (from naval } \\
\text { stations) } \\
(7) \\
\end{array}$ & $\begin{array}{l}\text { Including } \\
\text { Latin } \\
\text { America } \\
\text { (from naval } \\
\text { stations) } \\
(8) \\
\end{array}$ & $\begin{array}{l}\text { Alternative } \\
\text { Version of } \\
\text { Curtin data } \\
\text { on Africa } \\
\text { (9) }\end{array}$ & $\begin{array}{c}\text { Alternative } \\
\text { Version of } \\
\text { Curtin data } \\
\text { on Africa } \\
(10)\end{array}$ & $\begin{array}{l}\text { Using Log of } \\
\text { Ratio of } \\
\text { Colonial to } \\
\text { European } \\
\text { Mortality } \\
\quad(11) \\
\end{array}$ & $\begin{array}{l}\text { Using Log of } \\
\text { Ratio of } \\
\text { Colonial to } \\
\text { European } \\
\text { Mortality } \\
\quad(12) \\
\end{array}$ \\
\hline \multicolumn{13}{|c|}{ Panel A: Two Stage Least Squares } \\
\hline $\begin{array}{l}\text { Average Protection Against } \\
\text { Expropriation Risk, 1985-199؛ }\end{array}$ & $\begin{array}{c}1.0 \\
(0.25)\end{array}$ & $\begin{array}{c}1.1 \\
(0.33)\end{array}$ & $\begin{array}{c}0.84 \\
(0.17)\end{array}$ & $\begin{array}{c}0.82 \\
(0.20)\end{array}$ & $\begin{array}{c}0.93 \\
(0.17)\end{array}$ & $\begin{array}{c}0.96 \\
(0.25)\end{array}$ & $\begin{array}{c}0.93 \\
(0.16)\end{array}$ & $\begin{array}{c}0.95 \\
(0.21)\end{array}$ & $\begin{array}{c}0.9 \\
(0.15)\end{array}$ & $\begin{array}{c}0.91 \\
(0.20)\end{array}$ & $\begin{array}{c}0.99 \\
(0.18)\end{array}$ & $\begin{array}{c}1.00 \\
(0.25)\end{array}$ \\
\hline Latitude & & $\begin{array}{l}-0.57 \\
(1.90)\end{array}$ & & $\begin{array}{c}0.29 \\
(1.30)\end{array}$ & & $\begin{array}{l}-0.34 \\
(1.50)\end{array}$ & & $\begin{array}{l}-0.27 \\
(1.30)\end{array}$ & & $\begin{array}{l}-0.11 \\
(1.20)\end{array}$ & & $\begin{array}{r}-0.65 \\
(1.4)\end{array}$ \\
\hline \multicolumn{13}{|c|}{ Panel B: First-Stage for Average Protection against Expropriation Risk in 1985-95 } \\
\hline Log Mortality & $\begin{array}{l}-0.88 \\
(0.27)\end{array}$ & $\begin{array}{l}-0.77 \\
(0.30)\end{array}$ & $\begin{array}{c}-0.7 \\
(0.18)\end{array}$ & $\begin{array}{c}-0.6 \\
(0.19)\end{array}$ & $\begin{array}{l}-0.58 \\
(0.14)\end{array}$ & $\begin{array}{l}-0.47 \\
(0.16)\end{array}$ & $\begin{array}{l}-0.61 \\
(0.13)\end{array}$ & $\begin{array}{l}-0.52 \\
(0.14)\end{array}$ & $\begin{array}{l}-0.75 \\
(0.15)\end{array}$ & $\begin{array}{l}-0.66 \\
(0.17)\end{array}$ & $\begin{array}{l}-0.59 \\
(0.13)\end{array}$ & $\begin{array}{l}-0.49 \\
(0.14)\end{array}$ \\
\hline Latitude & & $\begin{array}{c}1.60 \\
(1.80)\end{array}$ & & $\begin{array}{c}1.80 \\
(1.80)\end{array}$ & & $\begin{array}{l}2.23 \\
(1.60)\end{array}$ & & $\begin{array}{l}2.00 \\
(1.30)\end{array}$ & & $\begin{array}{l}1.40 \\
(1.40)\end{array}$ & & $\begin{array}{c}2.1 \\
(1.3)\end{array}$ \\
\hline Adjusted R-Squared & 0.38 & 0.37 & 0.3 & 0.3 & 0.27 & 0.29 & 0.26 & 0.28 & 0.29 & 0.29 & 0.23 & 0.25 \\
\hline \multicolumn{13}{|c|}{ Panel C: Ordinary Least Squares } \\
\hline $\begin{array}{l}\text { Expropriation Risk } \\
1985-1995\end{array}$ & $\begin{array}{c}0.63 \\
(0.12)\end{array}$ & $\begin{array}{c}0.57 \\
(0.14)\end{array}$ & $\begin{array}{c}0.55 \\
(0.08)\end{array}$ & $\begin{array}{c}0.5 \\
(0.08)\end{array}$ & $\begin{array}{c}0.54 \\
(0.07)\end{array}$ & $\begin{array}{c}0.47 \\
(0.08)\end{array}$ & $\begin{array}{c}0.52 \\
(0.06)\end{array}$ & $\begin{array}{c}0.46 \\
(0.07)\end{array}$ & $\begin{array}{c}0.52 \\
(0.06)\end{array}$ & $\begin{array}{c}0.46 \\
(0.07)\end{array}$ & $\begin{array}{c}0.52 \\
(0.06)\end{array}$ & $\begin{array}{c}0.46 \\
(0.07)\end{array}$ \\
\hline Number of Observations & 17 & 17 & 31 & 31 & 45 & 45 & 64 & 64 & 64 & 64 & 64 & 64 \\
\hline
\end{tabular}

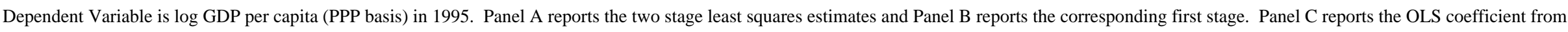

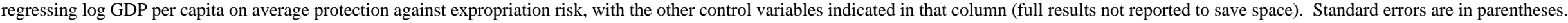

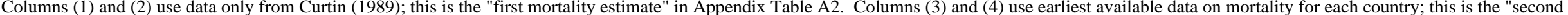

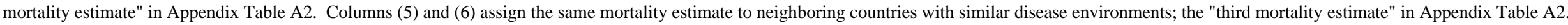

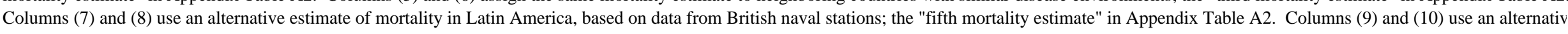
version of the Curtin estimates for Africa, which uses data only from long sample periods, and bishops for Latin America (the last column in Appendix Table A2).

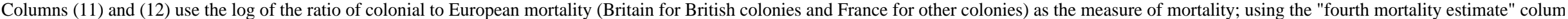
in Appendix Table A2. See Appendix Table A1 for more detailed variable definitions and sources. 
Table 6

IV Regressions of log GDP per capita with Additional Controls

\begin{tabular}{|c|c|c|c|c|c|c|c|}
\hline & $\begin{array}{c}\text { Base } \\
\text { Sample } \\
(1)\end{array}$ & $\begin{array}{c}\text { Base } \\
\text { Sample } \\
(2)\end{array}$ & $\begin{array}{c}\text { Base } \\
\text { Sample } \\
(3)\end{array}$ & $\begin{array}{c}\text { Base } \\
\text { Sample } \\
(4)\end{array}$ & $\begin{array}{c}\text { Base } \\
\text { Sample } \\
(5)\end{array}$ & $\begin{array}{c}\text { Base } \\
\text { Sample } \\
(6)\end{array}$ & $\begin{array}{c}\text { Base } \\
\text { Sample } \\
(7) \\
\end{array}$ \\
\hline \multicolumn{8}{|c|}{ Panel A: Two Stage Least Squares } \\
\hline $\begin{array}{l}\text { Average Protection Against } \\
\text { Expropriation Risk, 1985-1995 }\end{array}$ & $\begin{array}{l}1.10 \\
(0.19)\end{array}$ & $\begin{array}{c}1.10 \\
(0.26)\end{array}$ & $\begin{array}{c}1.1 \\
(0.19)\end{array}$ & $\begin{array}{c}1.2 \\
(0.29)\end{array}$ & $\begin{array}{c}0.91 \\
(0.15)\end{array}$ & $\begin{array}{l}0.95 \\
(0.23)\end{array}$ & $\begin{array}{c}1.00 \\
(0.23)\end{array}$ \\
\hline Latitude & & $\begin{array}{l}-0.58 \\
(1.30)\end{array}$ & & $\begin{array}{c}-1.0 \\
(1.50)\end{array}$ & & $\begin{array}{l}-0.44 \\
(1.40)\end{array}$ & $\begin{array}{l}-0.83 \\
(1.4)\end{array}$ \\
\hline Belgian Colonial Dummy & $\begin{array}{c}2.4 \\
(1.20)\end{array}$ & $\begin{array}{c}2.5 \\
(1.20)\end{array}$ & & & & & $\begin{array}{c}1.7 \\
(1.30)\end{array}$ \\
\hline French Colonial Dummy & $\begin{array}{c}0.66 \\
(0.38)\end{array}$ & $\begin{array}{c}0.72 \\
(0.44)\end{array}$ & & & & & $\begin{array}{c}0.27 \\
(0.72)\end{array}$ \\
\hline Spanish Colonial Dummy & $\begin{array}{c}1.1 \\
(0.33)\end{array}$ & $\begin{array}{c}1.1 \\
(0.37)\end{array}$ & & & & & $\begin{array}{c}0.1 \\
(0.70)\end{array}$ \\
\hline French legal origin dummy & & & $\begin{array}{c}1.0 \\
(0.33)\end{array}$ & $\begin{array}{c}1.1 \\
(0.41)\end{array}$ & & & $\begin{array}{c}0.23 \\
(0.75)\end{array}$ \\
\hline p-value for Religion Variables & & & & & {$[0.001]$} & {$[0.002]$} & {$[0.52]$} \\
\hline
\end{tabular}

Panel B: First-Stage for Average Protection against Expropriation Risk in 1985-95

\begin{tabular}{|c|c|c|c|c|c|c|c|}
\hline Log Mortality & $\begin{array}{l}-0.57 \\
(0.14)\end{array}$ & $\begin{array}{c}-0.5 \\
(0.16)\end{array}$ & $\begin{array}{l}-0.54 \\
(0.13)\end{array}$ & $\begin{array}{l}-0.44 \\
(0.14)\end{array}$ & $\begin{array}{l}-0.58 \\
(0.13)\end{array}$ & $\begin{array}{l}-0.46 \\
(0.15)\end{array}$ & $\begin{array}{c}-0.7 \\
(0.22)\end{array}$ \\
\hline Latitude & & $\begin{array}{l}1.5 \\
(1.4)\end{array}$ & & $\begin{array}{l}2.1 \\
(1.3)\end{array}$ & & $\begin{array}{l}2.4 \\
(1.4)\end{array}$ & $\begin{array}{l}1.6 \\
(1.6)\end{array}$ \\
\hline French legal origin & & & $\begin{array}{l}-0.8 \\
(0.3)\end{array}$ & $\begin{array}{l}-0.8 \\
(0.3)\end{array}$ & & & $\begin{array}{l}-0.9 \\
(1.1)\end{array}$ \\
\hline Belgian Colonial Dummy & $\begin{array}{l}-2.9 \\
(1.3)\end{array}$ & $\begin{array}{l}-2.7 \\
(1.3)\end{array}$ & & & & & $\begin{array}{l}-1.6 \\
(1.7)\end{array}$ \\
\hline French Colonial Dummy & $\begin{array}{l}-0.51 \\
(0.43)\end{array}$ & $\begin{array}{c}-0.6 \\
(0.40)\end{array}$ & & & & & $\begin{array}{c}0.8 \\
(1.10)\end{array}$ \\
\hline Spanish Colonial Dummy & $\begin{array}{l}-0.66 \\
(0.40)\end{array}$ & $\begin{array}{c}-0.6 \\
(0.40)\end{array}$ & & & & & $\begin{array}{c}0.9 \\
(1.00)\end{array}$ \\
\hline Adjusted R-Squared & 0.31 & 0.31 & 0.31 & 0.33 & 0.28 & 0.3 & 0.3 \\
\hline \multicolumn{8}{|c|}{ Panel C: Ordinary Least Squares } \\
\hline Expropriation Risk 1985-1995 & $\begin{array}{c}0.54 \\
(0.06)\end{array}$ & $\begin{array}{c}0.5 \\
(0.06)\end{array}$ & $\begin{array}{c}0.57 \\
(0.07)\end{array}$ & $\begin{array}{c}0.51 \\
(0.07)\end{array}$ & $\begin{array}{c}0.53 \\
(0.06)\end{array}$ & $\begin{array}{c}0.46 \\
(0.06)\end{array}$ & $\begin{array}{c}0.46 \\
(0.06)\end{array}$ \\
\hline
\end{tabular}

Panel A reports the two stage least squares estimates with log GDP per capita (PPP basis) in 1995 as dependent variable, and Panel B reports the corresponding first stage. The Dutch, Italian, German and Portuguese colonial dummies are not significant in the second or first stage and are not reported (to save space); the religion variables are included in the first stage of columns (5) and (6) but not reported here (to save space). Panel C reports the OLS coefficient from regressing log GDP per capita on average protection against expropriation risk, with the other control variables indicated in that column (full results not reported to save space). Standard errors are in parentheses. All regressions have 64 observations. The religion variables are 100 times percentage of population that are Catholics, Muslims, and "other" religions; Protestant is the base case. Our sample is all either French or British legal origin (as defined by La Porta et al 1999.) 
Table 7

Robustness Checks for IV Regressions of log GDP per capita

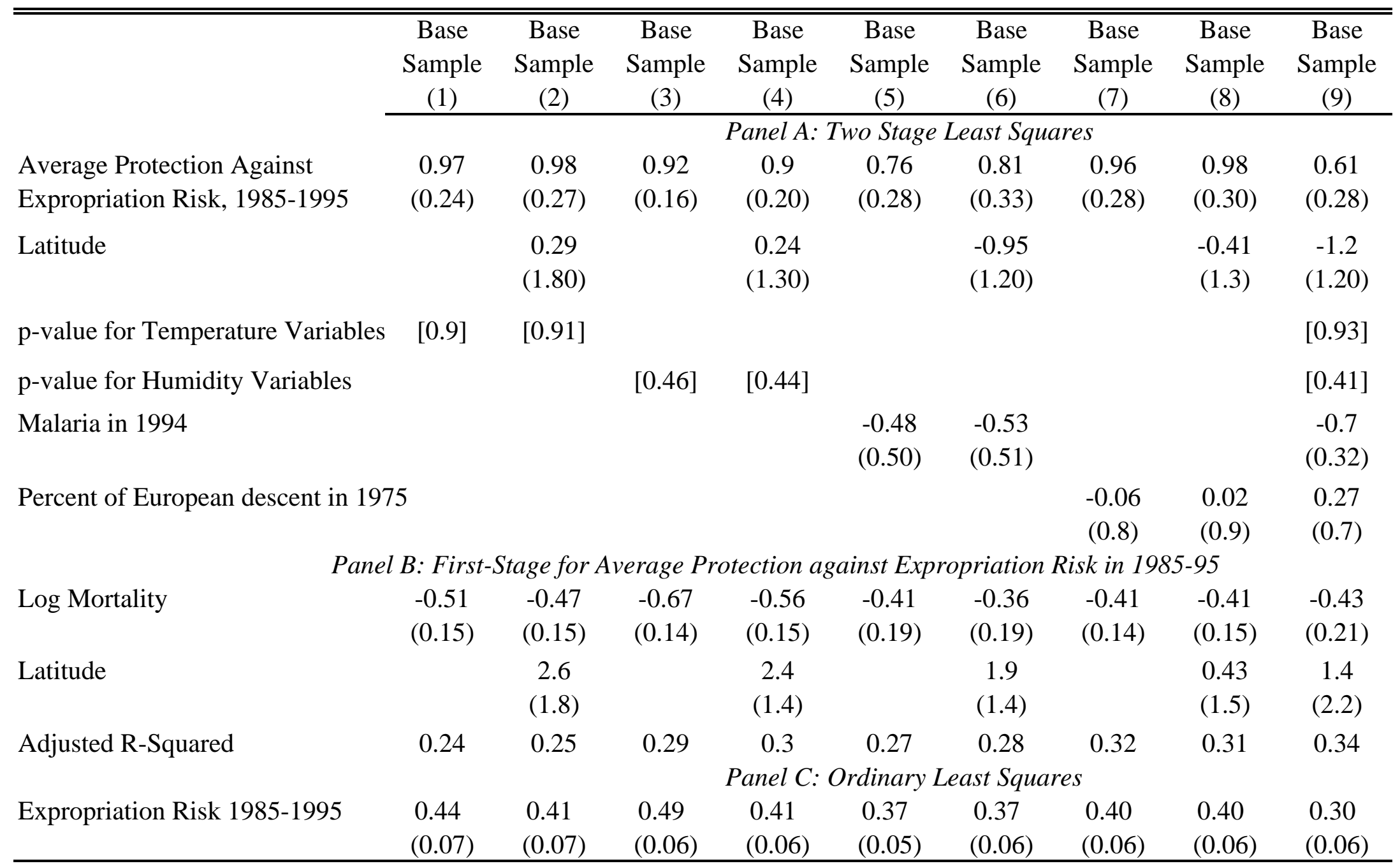

Panel A reports the two stage least squares estimates with log GDP per capita (PPP basis) in 1995, and Panel B reports the corresponding first stages.

Panel C reports the OLS coefficient from regressing log GDP per capita on average protection against expropriation risk, with the other control variables indicated in that column (full results not reported to save space). Standard errors are in parentheses. All regressions have 64 observations, except those including malaria and percent of European descent in 1975, which have 61 observations. The temperature and humidity variables are: average, minimum and maximum monthly high temperatures, and minimum and maximum monthly low temperatures, and morning minimum and maximum humidity, and afternoon minimum and maximum humidity. In the table we report joint significance levels for these variables (from Philip Parker, 1997). See Appendix Table A1 for more detailed variable definitions and sources. 
Table 8

Further Robustness Checks for IV Regressions of log GDP per capita

\begin{tabular}{|c|c|c|c|c|c|c|c|c|c|}
\hline & $\begin{array}{c}\text { Base } \\
\text { Sample } \\
\text { (1) }\end{array}$ & $\begin{array}{c}\text { Base } \\
\text { Sample } \\
(2)\end{array}$ & $\begin{array}{c}\text { Base } \\
\text { Sample } \\
(3)\end{array}$ & $\begin{array}{c}\text { Base } \\
\text { Sample } \\
(4)\end{array}$ & $\begin{array}{c}\text { Base } \\
\text { Sample } \\
(5)\end{array}$ & $\begin{array}{c}\text { Base } \\
\text { Sample } \\
(6)\end{array}$ & $\begin{array}{c}\text { Base } \\
\text { Sample } \\
(7)\end{array}$ & $\begin{array}{c}\text { Base } \\
\text { Sample } \\
(8)\end{array}$ & $\begin{array}{c}\text { Base } \\
\text { Sample } \\
(9)\end{array}$ \\
\hline \multicolumn{10}{|c|}{ Panel A: Two Stage Least Squares } \\
\hline $\begin{array}{l}\text { Average Protection Against } \\
\text { Expropriation Risk, 1985-1995 }\end{array}$ & $\begin{array}{c}0.93 \\
(0.19)\end{array}$ & $\begin{array}{c}0.98 \\
(0.25)\end{array}$ & $\begin{array}{c}1.1 \\
(0.28)\end{array}$ & $\begin{array}{c}1.2 \\
(0.34)\end{array}$ & $\begin{array}{c}1 \\
(0.19)\end{array}$ & $\begin{array}{c}1.1 \\
(0.28)\end{array}$ & $\begin{array}{c}0.74 \\
(0.13)\end{array}$ & $\begin{array}{c}0.77 \\
(0.16)\end{array}$ & $\begin{array}{c}0.87 \\
(0.28)\end{array}$ \\
\hline Latitude & & $\begin{array}{l}-0.7 \\
(1.4)\end{array}$ & & $\begin{array}{l}-0.12 \\
(1.6)\end{array}$ & & $\begin{array}{l}-0.72 \\
(1.5)\end{array}$ & & $\begin{array}{l}-0.66 \\
(1.0)\end{array}$ & $\begin{array}{l}-1.7 \\
(1.4)\end{array}$ \\
\hline P-Value for Soil Quality & {$[0.43]$} & {$[0.51]$} & & & & & & & 0.54 \\
\hline P-Value for Natural Resources & & & {$[0.59]$} & [0.63] & & & & & 0.91 \\
\hline Dummy for being landlocked & & & & & $\begin{array}{c}0.68 \\
(0.54)\end{array}$ & $\begin{array}{c}0.76 \\
(0.63)\end{array}$ & & & $\begin{array}{l}0.7 \\
-0.5\end{array}$ \\
\hline Ethnolinguistic fragmentation & & & & & & & $\begin{array}{c}-1.1 \\
(0.32)\end{array}$ & $\begin{array}{l}-1.1 \\
(0.34)\end{array}$ & $\begin{array}{c}-1.7 \\
(0.50)\end{array}$ \\
\hline \multicolumn{10}{|c|}{ Panel B: First-Stage for Average Protection against Expropriation Risk in 1985-95 } \\
\hline Log Mortality & $\begin{array}{l}-0.59 \\
(0.15)\end{array}$ & $\begin{array}{c}-0.5 \\
(0.16)\end{array}$ & $\begin{array}{l}-0.46 \\
(0.14)\end{array}$ & $\begin{array}{l}-0.41 \\
(0.15)\end{array}$ & $\begin{array}{l}-0.55 \\
(0.13)\end{array}$ & $\begin{array}{l}-0.45 \\
(0.14)\end{array}$ & $\begin{array}{l}-0.64 \\
(0.15)\end{array}$ & $\begin{array}{l}-0.56 \\
(0.15)\end{array}$ & $\begin{array}{l}-0.42 \\
(0.17)\end{array}$ \\
\hline Latitude & & $\begin{array}{c}2.1 \\
(1.4)\end{array}$ & & $\begin{array}{c}1.3 \\
(1.4)\end{array}$ & & $\begin{array}{c}2.2 \\
(1.3)\end{array}$ & & $\begin{array}{c}2.3 \\
(1.4)\end{array}$ & $\begin{array}{c}2.6 \\
(1.6)\end{array}$ \\
\hline Adjusted R-Squared & 0.24 & 0.25 & 0.24 & 0.24 & 0.28 & 0.3 & 0.25 & 0.27 & 0.28 \\
\hline \multicolumn{10}{|c|}{ Panel C: Ordinary Least Squares } \\
\hline Expropriation Risk 1985-1995 & $\begin{array}{l}0.50 \\
(0.06)\end{array}$ & $\begin{array}{l}0.46 \\
(0.07)\end{array}$ & $\begin{array}{l}0.50 \\
(0.07)\end{array}$ & $\begin{array}{l}0.46 \\
(0.07)\end{array}$ & $\begin{array}{l}0.51 \\
(0.07)\end{array}$ & $\begin{array}{l}0.44 \\
(0.07)\end{array}$ & $\begin{array}{l}0.52 \\
(0.06)\end{array}$ & $\begin{array}{l}0.46 \\
(0.07)\end{array}$ & $\begin{array}{l}0.44 \\
(0.07)\end{array}$ \\
\hline
\end{tabular}

Dependent Variable is log GDP per capita (PPP basis) in 1995. Panel A reports the two stage least squares estimates and Panel B reports the

corresponding first stages. Panel C reports the OLS coefficient from regressing log GDP per capita on average protection against expropriation risk, with the other control variables indicated in that column (full results not reported to save space). Standard errors are in parentheses. All regressions have 64 observations, except those including natural resources, which have 63 observations. Measures of natural resources are: percent of world gold reserves today, percent of world iron reserves today, percent of world zinc reserves today, number of minerals present in country, and oil resources (thousands of barrels per capita.) Measures of soil quality/climate are steppe (low latitude), desert (low latitude), steppe (middle latitude), desert (middle latitude), dry steppe wasteland, desert dry winter, and highland. 
Table 9

Overidentification Tests

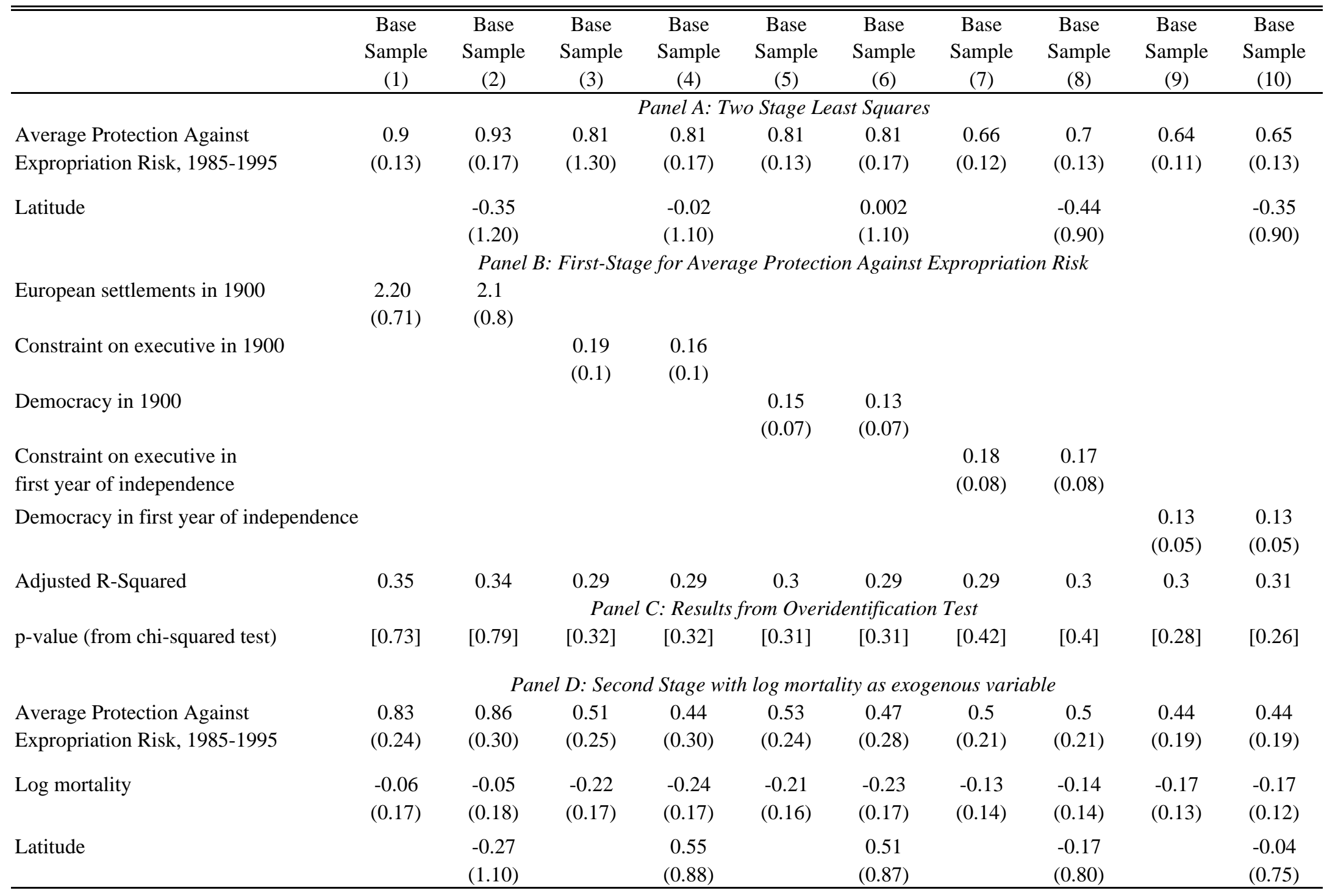

Panel A reports the two stage least squares estimates with log GDP per capita (PPP basis) in 1995 as the dependent variable, and Panel B reports the corresponding first stage (latitude is included in even numbered columns but is never significant and not reported here to save space). Panel C reports the p-value for the null hypothesis that the coefficient on average protection against expropriation risk in the second stage regression (i.e., Panel A) is the same as when instrumented using log mortality of settlers in addition to the indicated instruments; the two covariance matricies are based on a common estimate of the disturbance variance. Panel D reports results from the regression in which log mortality is included as an exogenous variable and current institutions are instrumented using the alternative instrument indicated (latitude is included in even columns but is never significant and not reported here to save space). Standard errors are in parentheses. All regressions with constraint on executive and democracy in first year of independence also include years since independence as a regressor. All regressions have 59 observations, except those with European sett] 


\section{Variable}

Log GDP per capita (PPP) in 1995

Log GDP per capita (PPP) in 1975

Average Protection against

Expropriation Risk, 1985-95

Constraint on Executive in 1990

Constraint on Executive in 1970

Constraint on Executive in 1900 Constraint on Executive in first year of independence

Democracy in 1900

Democracy in First Year of

Independence

European settlements in 1900

Percent of European descent 1975 Ethnolinguistic Fragmentation

\section{Religion Variables}

French legal origin dummy

Colonial Dummies

Temperature Variables

Humidity Variables

Soil Quality

Natural Resources

Dummy for Landlocked

Malaria in 1994

Latitude

Log Mortality

-

Law and Order Tradition in 1995 Property Rights in 1997

Rule of Law 1995

Efficiency of the Judiciary

\section{Description}

Logarithm of GDP per capita, on Purchasing Power Parity Basis. In our base sample this ranges from 6.1 to 10.2. Logarithm of GDP per capita, on Purchasing Power Parity Basis. In our base sample this ranges from 6.1 to 10.2. This is the first date for which PPP GDP per capita is available.

Risk of expropriation of private foreign investment by government, from 0 to 10 , where a higher score means less risk. We calculated the mean value for the scores in all years from 1985 to 1995 . In our base sample this ranges from 3.5 to 10

A seven category scale, from 1 to 7 , with a higher score indicating more constraints. Score of 1 indicates unlimited authority; score of 3 indicates slight to moderate limitations; score of 5 indicates substantial limitations; score of 7 indicates executive parity or subordination. Scores of 2, 4, and 6 indicate intermediate values.

A seven category scale, from 1 to 7 , with a higher score indicating more constraints. Score of 1 indicates unlimite authority; score of 3 indicates slight to moderate limitations, score of 5 indicates substantial limitations; score of 7 indicates executive parity or subordination. Scores of 2,4 , and 6 indicate intermediate values. Set equal to 1 if country was not independent on that date.

From 1 to 7 . Coding as for Constraint on Executive in 1990 and 1970. Set equal to 1 if country was not independent at that date.

From 1 to 7. Coding as for Constraint on Executive in 1970. Date of independence is first year that country

An eleven category scale, from 0 to 10 , with a higher score indicating more democracy. Points are awarded on three dimensions: Competitiveness of Political Participation (from 1 to 3); Competitiveness of Executive Recruitment (from 1 to 2 , with a bonus of 1 point if there is an election

From 0 to 10 . Coding as for Democracy in 1900. Date of independence is first year that country appears in Polity III dataset

Percent of population that was European or of European descent in 1900. Ranges from 0 to 0.99 in our base sample.

Percent of population that was European or of European descent in 1975. Ranges from 0 to 1 in our base sample. Average of five different indices of ethnolinguistic fragmentation.

Percentage of the population that belonged to the three most widely spread religions of the world in 1980 (or for 1990-95 for countries formed more recently). The four classifications are: Roman Catholic, Protestant, Muslin, and "other".

Legal origin of the company law or commercial code of each country. All the countries in our base sample are either of French Company law or con either of French Commercia Code Orgin wa a Britih. French, Ge Portuguese colony. Portuguese colony.

Temperature variables are average temperature, minimum monthly high, maximum monthly high, minimum monthly low, and maximum monthly low, all in centigrade.

Humidity variables are morning minimum, morning maximum, afternoon minimum, and afternoon maximum, all percent.

Measures of soil quality/climate are steppe (low latitude), desert (low latitude), steppe (middle latitude), desert (middle latitude), dry steppe wasteland, desert dry winter, and highland.

, percent of world iron reserves today, 作 Dummy variable equal to 1 if country does not adjoin the sea.

Malaria in 1994 is percent of people living in area where falciparum malaria is endemic Absolute value of the latitude of the country, scaled to take values between 0 and 1 , where 0 is the equator Log of estimated settler mortality. From 1.7 to 6.2 .

Law and Order Tradition in 1995, on a scale from 0 to 6 , where a higher score indicates stronger law and order. Law and Order Tradition in 1995 , on a scale from 0 to 6 , where a higher score indicates stronger law and order
Protection of property rights, on a scale from 1 to 5 , where a higher score indicates less secure property rights. "Equality of citizens under the law and access of citizens to a non-discriminatory judiciary"; from 0 to 10 , with a higher score indicating a better rule of law.

Efficiency of the judiciary, average between 1980 and 1983, on a scale from 1 to 10, with a higher score indicating a more efficient judiciary.
Source

World Bank, World Development Indicators, CD-Rom, 1999

World Bank, World Development Indicators, CD-Rom, 1999

Dataset obtained directly from Political Risk Services, September 1999. This data was previously used by Knack and Keefer (1995) and was organized in electronic orm by the IRIS Center (University of Maryland). The original compilers of this data re Political Risk Services.

任 dataset, downloaded from Inter-University Consortium for Political and Social Research. Variable described in Gurr 1997.

Polity III dataset, downloaded from Inter-University Consortium for Political and Social Research. Variable described in Gurr 1997.

Polity III dataset, downloaded from Inter-University Consortium for Political and Social Research. Variable described in Gurr 1997.

Polity III dataset, downloaded from Inter-University Consortium for Political and Social Research. Variable described in Gurr 1997.

Polity III dataset, downloaded from Inter-University Consortium for Political and Social Research. Variable described in Gurr 1997.

Polity III dataset, downloaded from Inter-University Consortium for Political and Social Research. Variable described in Gurr 1997.

Constructed from McEvedy and Jones (1978), Curtin et al (1995) and some additional ources (see Appendix Table A5).

Constructed from McEvedy and Jones (1978), Curtin et al (1995) and some additional

ources (see Appendix Table A5).

Easterly and Levine (1997), as used in La Porta et al (1999).

La Porta et al (1999)

La Porta et al (1999)

La Porta et al (1999)

Parker (1997)

Parker (1997)

Parker (1997)

Parker (1997)

Parker (1997)

Gallup and Sachs 1998

La Porta et al (1999)

See Appendix B for details on how this variable is constructed; primary sources are Curtin (1989 and 1998); Gutierrez (1986). The full dataset is in Appendix Table A2. Dataset obtained directly from Political Risk Services, September 1999. This data

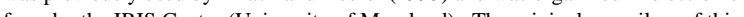

nes, Johnson, Kirkpatrick (1997)

Gwartney and Lawson (1997)

As reported in Mauro 1995, from Business International 


\begin{tabular}{|c|c|c|c|c|c|c|c|c|c|}
\hline & & & $\begin{array}{l}\text { Appendix Tabl } \\
\text { Data on Mortal }\end{array}$ & $\begin{array}{l}\text { le A2 } \\
\text { lity }\end{array}$ & & & & & \\
\hline & $\begin{array}{l}\text { Abbreviated } \\
\text { name used } \\
\text { in graphs }\end{array}$ & $\begin{array}{l}\text { Log GDP } \\
\text { per capita } \\
\text { (PPP) in } \\
1995\end{array}$ & $\begin{array}{l}\text { Average } \\
\text { Protection } \\
\text { Against } \\
\text { Expropriation } \\
\text { Risk 1985-95 }\end{array}$ & $\begin{array}{l}\text { First } \\
\text { mortality } \\
\text { estimate }\end{array}$ & $\begin{array}{l}\text { Second } \\
\text { mortality } \\
\text { estimate }\end{array}$ & $\begin{array}{l}\text { Third } \\
\text { mortality } \\
\text { estimate }\end{array}$ & \begin{tabular}{|l} 
Fourth \\
mortality \\
estimate \\
(used in \\
main \\
analysis)
\end{tabular} & $\begin{array}{l}\text { Fifth } \\
\text { mortality } \\
\text { estimate }\end{array}$ & $\begin{array}{l}\text { Alternative } \\
\text { version of } \\
\text { Curtin data } \\
\text { on Africa }\end{array}$ \\
\hline \multicolumn{10}{|l|}{ Former Colonies } \\
\hline Angola & AGO & 7.77 & 5.36 & & & 280 & 280 & 280 & 280 \\
\hline Argentina & ARG & 9.13 & 6.39 & & & & 68.9 & 71 & 68.9 \\
\hline Australia & AUS & 9.90 & 9.32 & & & & 8.55 & 8.55 & 8.55 \\
\hline Burkina Faso & BFA & 6.85 & 4.45 & & 280 & 280 & 280 & 280 & 280 \\
\hline Bangladesh & BGD & 6.88 & 5.14 & 71.41 & 71.41 & 71.41 & 71.41 & 71.41 & 71.41 \\
\hline Bahamas & BHS & 9.29 & 7.50 & & & & 85 & 85 & 85 \\
\hline Bolivia & $\mathrm{BOL}$ & 7.93 & 5.64 & & & & 71 & 71 & 71 \\
\hline Brazil & BRA & 8.73 & 7.91 & & & & 71 & 71 & 71 \\
\hline Barbados & BRB & 9.27 & & 85 & 85 & 85 & 85 & 85 & 85 \\
\hline Central African Fed. & CAF & 7.19 & & & 280 & 280 & 280 & 280 & 280 \\
\hline Canada & CAN & 9.99 & 9.73 & 16.1 & 16.1 & 16.1 & 16.1 & 16.1 & 16.1 \\
\hline Chile & $\mathrm{CHL}$ & 9.34 & 7.82 & & & & 68.9 & 71 & 68.9 \\
\hline Cote d'Ivoire & CIV & 7.44 & 7.00 & & & 668 & 668 & 668 & 483 \\
\hline Cameroon & CMR & 7.50 & 6.45 & & & 280 & 280 & 280 & 280 \\
\hline Congo (French) & COG & 7.42 & 4.68 & & 240 & 240 & 240 & 240 & 280 \\
\hline Colombia & COL & 8.81 & 7.32 & & & & 71 & 71 & 71 \\
\hline Costa Rica & CRI & 8.79 & 7.05 & & & & 78.1 & 78.1 & 78.1 \\
\hline Dominican $\mathrm{Re}$ & DOM & 8.36 & 6.18 & & & 130 & 130 & 130 & 130 \\
\hline Algeria & DZA & 8.39 & 6.50 & 78.2 & 78.2 & 78.2 & 78.2 & 78.2 & 78.2 \\
\hline Ecuador & ECU & 8.47 & 6.55 & & & & 71 & 71 & 71 \\
\hline Egypt & EGY & 7.95 & 6.77 & & 67.8 & 67.8 & 67.8 & 67.8 & 67.8 \\
\hline Ethiopia & ETH & 6.11 & 5.73 & & 26 & 26 & 26 & 26 & 26 \\
\hline Ghana & $\mathrm{GHA}$ & 7.37 & 6.27 & & & 668 & 668 & 668 & 483 \\
\hline Guinea & GIN & 7.49 & 6.55 & & & 483 & 483 & 483 & 483 \\
\hline Gambia & GMB & 7.27 & 8.27 & & 1470 & 1470 & 1470 & 1470 & 164.66 \\
\hline Guatemala & GTM & 8.29 & 5.14 & & & & 71 & 71 & 71 \\
\hline Guyana & GUY & 7.90 & 5.89 & 32.18 & 32.18 & 32.18 & 32.18 & 32.18 & 32.18 \\
\hline Hong Kong & HKG & 10.05 & 8.14 & & & 14.9 & 14.9 & 14.9 & 14.9 \\
\hline Honduras & HND & 7.69 & 5.32 & & & & 78.1 & 78.1 & 78.1 \\
\hline Haiti & $\mathrm{HTI}$ & 7.15 & 3.73 & & & & 130 & 130 & 130 \\
\hline India & DNI & 7.33 & 8.27 & 48.63 & 48.63 & 48.63 & 48.63 & 48.63 & 48.63 \\
\hline Indonesia & IND & 7.33 & 7.59 & 170 & 170 & 170 & 170 & 170 & 170 \\
\hline Jamaica & JAM & 8.19 & 7.09 & 130 & 130 & 130 & 130 & 130 & 130 \\
\hline Kenya & KEN & 7.06 & 6.05 & & & 145 & 145 & 145 & 280 \\
\hline Sri Lanka & LKA & 7.73 & 6.05 & 69.8 & 69.8 & 69.8 & 69.8 & 69.8 & 69.8 \\
\hline Morocco & MAR & 8.04 & 7.09 & & & 78.2 & 78.2 & 78.2 & 78.2 \\
\hline Madagascar & MDG & 6.84 & 4.45 & & 536.04 & 536.04 & 536.04 & 536.04 & 302 \\
\hline Mexico & MEX & 8.94 & 7.50 & & 71 & 71 & 71 & 71 & 71 \\
\hline Mali & MLI & 6.57 & 4.00 & & 2940 & 2940 & 2940 & 2940 & 280 \\
\hline Malta & MLT & 9.43 & 7.23 & 16.3 & 16.3 & 16.3 & 16.3 & 16.3 & 16.3 \\
\hline Myanmar & MMR & & 5.77 & 34.6 & 34.6 & 34.6 & 34.6 & 34.6 & 34.6 \\
\hline Mauritania & MRT & 7.41 & & & 280 & 280 & 280 & 280 & 280 \\
\hline Mauritius & MUS & 9.05 & & 30.5 & 30.5 & 30.5 & 30.5 & 30.5 & 30.5 \\
\hline Malaysia & MYS & 8.89 & 7.95 & 17.7 & 17.7 & 17.7 & 17.7 & 17.7 & 17.7 \\
\hline Niger & NER & 6.73 & 5.00 & & 400 & 400 & 400 & 400 & 280 \\
\hline Nigeria & NGA & 6.81 & 5.55 & & & 2004 & 2004 & 2004 & 483 \\
\hline Nicaragua & NIC & 7.54 & 5.23 & & & & 163.3 & 163.3 & 163.3 \\
\hline New Zealand & NZL & 9.76 & 9.73 & 8.55 & 8.55 & 8.55 & 8.55 & 8.55 & 8.55 \\
\hline Pakistan & PAK & 7.35 & 6.05 & & & 36.99 & 36.99 & 36.99 & 36.99 \\
\hline Panama & PAN & 8.84 & 5.91 & & & & 163.3 & 163.3 & 163.3 \\
\hline Peru & PER & 8.40 & 5.77 & & & & 71 & 71 & 71 \\
\hline Paraguay & PRY & 8.21 & 6.95 & & & & 78.1 & 78.1 & 78.1 \\
\hline Rwanda & RWA & 6.48 & & & & 280 & 280 & 280 & 280 \\
\hline Sudan & SDN & 7.31 & 4.00 & & 88.2 & 88.2 & 88.2 & 88.2 & 36.4 \\
\hline Senegal & SEN & 7.40 & 6.00 & 164.66 & 164.66 & 164.66 & 164.66 & 164.66 & 164.66 \\
\hline
\end{tabular}




\begin{tabular}{|c|c|c|c|c|c|c|c|c|c|}
\hline & $\begin{array}{l}\text { Abbreviated } \\
\text { name used } \\
\text { in graphs }\end{array}$ & $\begin{array}{l}\text { Log GDP } \\
\text { per capita } \\
(P P P) \text { in } \\
1995\end{array}$ & \begin{tabular}{l|} 
Average \\
Protection \\
Against \\
Expropriation \\
Risk 1985-95
\end{tabular} & $\begin{array}{l}\text { First } \\
\text { mortality } \\
\text { estimate }\end{array}$ & $\begin{array}{l}\text { Second } \\
\text { mortality } \\
\text { estimate }\end{array}$ & \begin{tabular}{|l|} 
Third \\
mortality \\
estimate
\end{tabular} & $\begin{array}{l}\text { Fourth } \\
\text { mortality } \\
\text { estimate } \\
\text { (used in } \\
\text { main } \\
\text { analysis) }\end{array}$ & $\begin{array}{l}\text { Fifth } \\
\text { mortality } \\
\text { estimate }\end{array}$ & $\begin{array}{l}\text { Alternative } \\
\text { version of } \\
\text { Curtin data } \\
\text { on Africa }\end{array}$ \\
\hline Sierra Leone & SLE & 6.25 & 5.82 & 483 & 483 & 483 & 483 & 483 & 483 \\
\hline El Salvador & SLV & 7.95 & 5.00 & & & & 78.1 & 78.1 & 78.1 \\
\hline Singapore & SGP & 10.15 & 9.32 & 17.7 & 17.7 & 17.7 & 17.7 & 17.7 & 17.7 \\
\hline Surinam & SUR & & 4.68 & & & 32.12 & 32.18 & 32.18 & 32.12 \\
\hline Chad & TCD & 6.84 & & & 280 & 280 & 280 & 280 & 280 \\
\hline Togo & TGO & 7.22 & 6.91 & & & 668 & 668 & 668 & 483 \\
\hline Trinidad and Tobago & TTO & 8.77 & 7.45 & 85 & 85 & 85 & 85 & 85 & 85 \\
\hline Tunisia & TUN & 8.48 & 6.45 & & 63 & 63 & 63 & 63 & 61 \\
\hline Tanzania & TZA & 6.25 & 6.64 & & & 145 & 145 & 145 & 280 \\
\hline Uganda & UGA & 6.97 & 4.45 & & & 280 & 280 & 280 & 280 \\
\hline Uruguary & URY & 9.03 & 7.00 & & & & 71 & 71 & 71 \\
\hline USA & USA & 10.22 & 10.00 & 15 & 15 & 15 & 15 & 15 & 15 \\
\hline Venezuela & VEN & 9.07 & 7.14 & & & & 78.1 & 78.1 & 78.1 \\
\hline Vietnam & VNM & 7.28 & 6.41 & & 140 & 140 & 140 & 140 & 140 \\
\hline South Africa & $\mathrm{ZAF}$ & 8.89 & 6.86 & 15.5 & 15.5 & 15.5 & 15.5 & 15.5 & 15.5 \\
\hline Zaire & ZAR & 6.87 & 3.50 & & & 240 & 240 & 240 & 280 \\
\hline \multicolumn{10}{|l|}{ European Colonizers } \\
\hline France & & & & 20.17 & 20.17 & 20.17 & 20.17 & 20.17 & 20.17 \\
\hline Britain & & & & 15.3 & 15.3 & 15.3 & 15.3 & 15.3 & 15.3 \\
\hline \multicolumn{10}{|c|}{$\begin{array}{l}\text { A blank indicates missing data. When mortality varies across different cities for a country, we use the lowest rate. Countries } \\
\text { in italics have reasonable mortality estimates, but they cannot be included in our basic sample as other data are missing. } \\
\text { Gutierrez shows that the ratio of mortality for bishops aged } 40-49 \text { is, by disease environment: low mortality } 10 \text { per } 1000 ; \\
\text { medium mortality, } 11 \text { per } 1000 \text {; high mortality, } 23 \text { per } 1000 \text {. We use these proportions and the death rate in Mexico from } \\
\text { Curtin to infer mortality in Latin America. The results would be essentially the same if we used Curtin (1989)'s Jamaica } \\
\text { estimate as the base case for calculating Latin American settler mortality using the Gutierrez estimates. }\end{array}$} \\
\hline \multicolumn{10}{|c|}{$\begin{array}{l}\text { Curtin (1964) reports average annual mortality from disease in the anti-slavery blockade (West Africa) as } 5.44 \% \text {, and } \\
\text { mortality from disease in the South American Naval Stations as } 0.77 \% \text {. Mortality at other naval stations is consistent with } \\
\text { the Curtin and Gutierrez estimates (comparing the ratios with West Africa): Mediterranean }(0.93 \%) \text {, East Indian }(1.51 \%) \text {, } \\
\text { West Indian }(1.81 \%) \text {, Home Station }(0.98 \%) \text {. }\end{array}$} \\
\hline \multicolumn{10}{|c|}{$\begin{array}{l}\text { The alternative mortality estimates are calculated as follows. First mortality estimate: data from Curtin (1989), "Death by } \\
\text { Migration" only. Second mortality estimate: data from "Death by Migration" plus earliest data for each country from Curtin } \\
\text { (1998), "Disease and Empire". Third mortality estimate: including neighbours with same disease environments and African } \\
\text { mortality for Kenya and Congo, from other Curtin sources discussed in the appendix. Fourth mortality estimate: using } \\
\text { Gutierrez (1986) data on bishops to estimate mortality in South America and the full set of Curtin estimates of mortality. Fifth } \\
\text { mortality estimate: using Curtin (1964) data from naval stations for Chile and Argentina. Alternative version of Curtin data: } \\
\text { using long sample periods from Curtin (1989) and (1998) and data on bishops to estimate mortality in South America. }\end{array}$} \\
\hline
\end{tabular}


Appendix Table A3

IV Regressions using GDP per capita in 1975

\begin{tabular}{|c|c|c|c|c|c|c|c|c|}
\hline & $\begin{array}{c}\text { Base } \\
\text { Sample } \\
(1)\end{array}$ & $\begin{array}{c}\text { Base } \\
\text { Sample } \\
(2)\end{array}$ & $\begin{array}{c}\text { Base } \\
\text { Sample } \\
\text { without } \\
\text { neo- } \\
\text { Europes } \\
\quad(3)\end{array}$ & $\begin{array}{c}\text { Base } \\
\text { Sample } \\
\text { without } \\
\text { neo- } \\
\text { Europes } \\
(4)\end{array}$ & $\begin{array}{c}\text { Base } \\
\text { Sample } \\
\text { without } \\
\text { Africa } \\
(5) \\
\end{array}$ & $\begin{array}{c}\text { Base } \\
\text { Sample } \\
\text { without } \\
\text { Africa } \\
(6)\end{array}$ & $\begin{array}{c}\text { Base } \\
\text { Sample } \\
\text { with } \\
\text { Continent } \\
\text { Dummies } \\
(7)\end{array}$ & $\begin{array}{c}\text { Base } \\
\text { Sample } \\
\text { with } \\
\text { Continent } \\
\text { Dummies } \\
(8)\end{array}$ \\
\hline \multicolumn{9}{|c|}{ Panel A: Two Stage Least Squares } \\
\hline Constraint on executive in 1970 & $\begin{array}{c}0.54 \\
(0.15)\end{array}$ & $\begin{array}{c}0.61 \\
(0.22)\end{array}$ & $\begin{array}{c}0.64 \\
(0.31)\end{array}$ & $\begin{array}{c}0.7 \\
(0.35)\end{array}$ & $\begin{array}{c}0.31 \\
(0.13)\end{array}$ & $\begin{array}{c}0.3 \\
(0.16)\end{array}$ & $\begin{array}{c}0.48 \\
(0.18)\end{array}$ & $\begin{array}{l}0.56 \\
(0.3)\end{array}$ \\
\hline Latitude & & $\begin{array}{c}-1.2 \\
(1.90)\end{array}$ & & $\begin{array}{l}-0.96 \\
(2.10)\end{array}$ & & $\begin{array}{c}0.1 \\
(1.50)\end{array}$ & & $\begin{array}{l}-1.3 \\
(1.8)\end{array}$ \\
\hline Asia Dummy & & & & & & & $\begin{array}{c}-1.1 \\
(0.48)\end{array}$ & $\begin{array}{c}-1.2 \\
(0.60)\end{array}$ \\
\hline Africa Dummy & & & & & & & $\begin{array}{l}-0.65 \\
(0.34)\end{array}$ & $\begin{array}{l}-0.65 \\
(0.39)\end{array}$ \\
\hline "Other" Continent Dummy & & & & & & & $\begin{array}{l}-0.9 \\
(0.7)\end{array}$ & $\begin{array}{c}-1 \\
(0.8)\end{array}$ \\
\hline Log Mortality & $\begin{array}{l}-0.82 \\
(0.21)\end{array}$ & $\begin{array}{c}\text { anel B: } F \\
-0.67 \\
(0.23)\end{array}$ & $\begin{array}{c}\text { st-Stage } \\
-0.54 \\
(0.23)\end{array}$ & $\begin{array}{c}\text { Constrai } \\
-0.5 \\
(0.24)\end{array}$ & $\begin{array}{c}\text { on Exect } \\
-1.5 \\
(0.44)\end{array}$ & $\begin{array}{c}\text { ve in } 1970 \\
-1.3 \\
(0.47)\end{array}$ & $\begin{array}{l}-0.79 \\
(0.27)\end{array}$ & $\begin{array}{l}-0.64 \\
(0.29)\end{array}$ \\
\hline Latitude & & $\begin{array}{l}3.40 \\
(2.20)\end{array}$ & & $\begin{array}{c}1.10 \\
(2.60)\end{array}$ & & $\begin{array}{l}3.30 \\
(2.80)\end{array}$ & & $\begin{array}{c}3 \\
(2.2)\end{array}$ \\
\hline Asia Dummy & & & & & & & $\begin{array}{l}-0.4 \\
(0.9)\end{array}$ & $\begin{array}{l}-0.21 \\
(0.90)\end{array}$ \\
\hline Africa Dummy & & & & & & & $\begin{array}{c}0.1 \\
(0.70)\end{array}$ & $\begin{array}{c}0.08 \\
(0.70)\end{array}$ \\
\hline "Other" Continent Dummy & & & & & & & $\begin{array}{c}1.7 \\
(1.10)\end{array}$ & $\begin{array}{c}1.6 \\
(1.10)\end{array}$ \\
\hline Adjusted R-Squared & 0.2 & 0.22 & 0.07 & 0.06 & 0.25 & 0.26 & 0.2 & 0.21 \\
\hline Constraint on executive in 1970 & $\begin{array}{c}0.16 \\
(0.05)\end{array}$ & $\begin{array}{c}0.13 \\
(0.05)\end{array}$ & $\begin{array}{c}\text { anel } C: \\
0.08 \\
(0.05)\end{array}$ & $\begin{array}{c}\text { dinary Le } \\
0.08 \\
(0.05)\end{array}$ & $\begin{array}{c}\text { Square } \\
0.13 \\
(0.06)\end{array}$ & $\begin{array}{c}0.11 \\
(0.07)\end{array}$ & $\begin{array}{l}0.11 \\
(0.04)\end{array}$ & $\begin{array}{l}0.09 \\
(0.04)\end{array}$ \\
\hline Number of Observations & 59 & 59 & 55 & 55 & 31 & 31 & 59 & 59 \\
\hline
\end{tabular}

Dependent Variable is log GDP per capita (PPP basis) in 1975. Constraint on Executive in 1970 is measured on a scale of 1 to 7, where a higher score represents more constraint, from the Polity III data set. Panel A reports the two stage least squares estimates and Panel B reports the corresponding first stage. Panel C reports the OLS coefficient from regressing log GDP pe capita on average protection against expropriation risk, with the other control variables indicated in that column (full results not reported to save space). Standard errors are in parentheses. In regressions with continent dummies, the dummy for America is omitted.

See Appendix Table A1 for more detailed variable definitions and sources. 


\begin{tabular}{|c|c|c|c|c|c|c|c|c|}
\hline & $\begin{array}{c}\text { Base } \\
\text { Sample } \\
(1)\end{array}$ & $\begin{array}{c}\text { Base } \\
\text { Sample } \\
(2)\end{array}$ & $\begin{array}{c}\text { Base } \\
\text { Sample } \\
\text { without neo } \\
\text { Europes } \\
(3)\end{array}$ & $\begin{array}{c}\text { Base } \\
\text { Sample } \\
\text { without neo- } \\
\text { Europes } \\
\text { (4) }\end{array}$ & $\begin{array}{c}\text { Base } \\
\text { Sample } \\
\text { without } \\
\text { Africa } \\
\quad(5)\end{array}$ & $\begin{array}{c}\text { Base } \\
\text { Sample } \\
\text { without } \\
\text { Africa } \\
(6)\end{array}$ & $\begin{array}{c}\text { Base } \\
\text { Sample } \\
\text { with } \\
\text { Continent } \\
\text { Dummies } \\
\text { (7) }\end{array}$ & $\begin{array}{c}\text { Base } \\
\text { Sample } \\
\text { with } \\
\text { Continent } \\
\text { Dummies } \\
\text { (8) }\end{array}$ \\
\hline \multicolumn{9}{|c|}{ Panel A: Two Stage Least Squares } \\
\hline $\begin{array}{l}\text { Constraint on Executive } \\
\text { in } 1990\end{array}$ & $\begin{array}{c}0.51 \\
(0.08)\end{array}$ & $\begin{array}{c}0.46 \\
0.90\end{array}$ & $\begin{array}{c}0.46 \\
(0.10)\end{array}$ & $\begin{array}{c}0.4 \\
(0.09)\end{array}$ & $\begin{array}{c}0.77 \\
(0.32)\end{array}$ & $\begin{array}{c}0.65 \\
(0.27)\end{array}$ & $\begin{array}{c}0.69 \\
(0.23)\end{array}$ & $\begin{array}{c}0.6 \\
(0.2)\end{array}$ \\
\hline Latitude & & $\begin{array}{c}1.3 \\
(0.92)\end{array}$ & & $\begin{array}{c}1.1 \\
(1.10)\end{array}$ & & $\begin{array}{c}1.8 \\
(1.40)\end{array}$ & & $\begin{array}{c}1.4 \\
(1.1)\end{array}$ \\
\hline Asia Dummy & & & & & & & $\begin{array}{c}0.31 \\
(0.60)\end{array}$ & $\begin{array}{c}0.23 \\
(0.53)\end{array}$ \\
\hline Africa Dummy & & & & & & & $\begin{array}{c}0.89 \\
(0.80)\end{array}$ & $\begin{array}{c}0.70 \\
(0.72)\end{array}$ \\
\hline "Other" Continent Dummy & & & & & & & $\begin{array}{c}-0.12 \\
(0.6)\end{array}$ & $\begin{array}{l}-0.16 \\
(0.6)\end{array}$ \\
\hline Log Mortality & $\begin{array}{c}-1.1 \\
(0.19)\end{array}$ & $\begin{array}{c}\text { Panel B } \\
-1.1 \\
(0.21)\end{array}$ & $\begin{array}{c}\text { First-Stage } f \\
-1.0 \\
(0.20)\end{array}$ & $\begin{array}{c}\text { or Constraint } \\
-1.0 \\
(0.22)\end{array}$ & $\begin{array}{c}\text { Executi } \\
-0.86 \\
(0.38)\end{array}$ & $\begin{array}{c}\text { in } 1990 \\
-0.9 \\
(0.40)\end{array}$ & $\begin{array}{l}-0.63 \\
(0.21)\end{array}$ & $\begin{array}{l}-0.64 \\
(0.22)\end{array}$ \\
\hline Latitude & & $\begin{array}{l}0.64 \\
(2.00)\end{array}$ & & $\begin{array}{l}-0.30 \\
(2.40)\end{array}$ & & $\begin{array}{l}-1.30 \\
(2.40)\end{array}$ & & $\begin{array}{l}-0.22 \\
(1.8)\end{array}$ \\
\hline Asia Dummy & & & & & & & $\begin{array}{l}-1.7 \\
(0.7)\end{array}$ & $\begin{array}{l}-1.7 \\
(0.7)\end{array}$ \\
\hline Africa Dummy & & & & & & & $\begin{array}{c}-2.3 \\
(0.53)\end{array}$ & $\begin{array}{c}-2.3 \\
(0.53)\end{array}$ \\
\hline "Other" Continent Dummy & & & & & & & $\begin{array}{c}-0.2 \\
(0.90)\end{array}$ & $\begin{array}{l}-0.17 \\
(0.91)\end{array}$ \\
\hline Adjusted R-Squared & 0.34 & 0.33 & 0.25 & 0.24 & 0.11 & 0.09 & 0.48 & 0.47 \\
\hline \multicolumn{9}{|c|}{ Panel C: Ordinary Least Squares } \\
\hline $\begin{array}{l}\text { Constraint on Executive } \\
\text { in } 1990\end{array}$ & $\begin{array}{c}0.29 \\
(0.04)\end{array}$ & $\begin{array}{c}0.25 \\
(0.04)\end{array}$ & $\begin{array}{c}0.24 \\
(0.04)\end{array}$ & $\begin{array}{c}0.23 \\
(0.04)\end{array}$ & $\begin{array}{c}0.23 \\
(0.07)\end{array}$ & $\begin{array}{c}0.22 \\
(0.07)\end{array}$ & $\begin{array}{l}0.19 \\
(0.05)\end{array}$ & $\begin{array}{l}0.17 \\
(0.05)\end{array}$ \\
\hline Number of Observations & 69 & 69 & 65 & 65 & 35 & 35 & 69 & 69 \\
\hline
\end{tabular}

Constraint on Executive in 1990 is measured on a scale, from 1 to 7 , with a higher score indicating more constraints on the arbitrary actions that the executive can take, from the Polity data set (see Appendix Table 1 for more detail). Panel A reports the two stage least squares estimates with log GDP per capita (PPP basis) in 1995 as the dependent variable, instrumenting for constraint on the executive using log settler mortality; Panel B reports the corresponding first stage. Panel C reports the OLS coefficient from regressing log GDP per capita on constraint on the executive in 1990, with the other control variables indicated in that column (full results not reported to save space). Standard errors are in parentheses. In regressions with continent dummies, the dummy for America is omitted. 
Appendix Table A4b

IV Regressions of log GDP per capita

\begin{tabular}{|c|c|c|c|c|c|c|c|c|}
\hline & $\begin{array}{c}\text { Base } \\
\text { Sample } \\
(1)\end{array}$ & $\begin{array}{c}\text { Base } \\
\text { Sample } \\
(2)\end{array}$ & $\begin{array}{c}\text { Base } \\
\text { Sample } \\
\text { without } \\
\text { neo- } \\
\text { Europes } \\
(3) \\
\end{array}$ & $\begin{array}{c}\text { Base } \\
\text { Sample } \\
\text { without } \\
\text { neo- } \\
\text { Europes } \\
(4) \\
\end{array}$ & $\begin{array}{c}\text { Base } \\
\text { Sample } \\
\text { without } \\
\text { Africa } \\
\text { (5) }\end{array}$ & $\begin{array}{c}\text { Base } \\
\text { Sample } \\
\text { without } \\
\text { Africa } \\
\text { (6) }\end{array}$ & $\begin{array}{c}\text { Base } \\
\text { Sample } \\
\text { with } \\
\text { Continent } \\
\text { Dummies } \\
(7) \\
\end{array}$ & $\begin{array}{c}\text { Base } \\
\text { Sample } \\
\text { with } \\
\text { Continent } \\
\text { Dummies } \\
\text { (8) }\end{array}$ \\
\hline \multicolumn{9}{|c|}{ Panel A: Two Stage Least Squares } \\
\hline Law and Order Tradition in 1995 & $\begin{array}{c}1.1 \\
(0.21)\end{array}$ & $\begin{array}{c}1.2 \\
(0.32)\end{array}$ & $\begin{array}{c}1.3 \\
(0.36)\end{array}$ & $\begin{array}{c}1.4 \\
(0.40)\end{array}$ & $\begin{array}{c}0.72 \\
(0.15)\end{array}$ & $\begin{array}{c}0.74 \\
(0.19)\end{array}$ & $\begin{array}{c}1 \\
(0.28)\end{array}$ & $\begin{array}{l}1.20 \\
(0.4)\end{array}$ \\
\hline Latitude & & $\begin{array}{c}-1.4 \\
(1.80)\end{array}$ & & $\begin{array}{c}-1.2 \\
(2.00)\end{array}$ & & $\begin{array}{l}-0.33 \\
(1.10)\end{array}$ & & $\begin{array}{l}-1.7 \\
(0.2)\end{array}$ \\
\hline Asia Dummy & & & & & & & $\begin{array}{c}-1.1 \\
(0.40)\end{array}$ & $\begin{array}{l}-1.30 \\
(0.50)\end{array}$ \\
\hline Africa Dummy & & & & & & & $\begin{array}{l}-0.70 \\
(0.30)\end{array}$ & $\begin{array}{l}-0.70 \\
(0.40)\end{array}$ \\
\hline "Other" Continent Dummy & & & & & & & $\begin{array}{l}-0.95 \\
(0.7)\end{array}$ & $\begin{array}{c}-1 \\
(0.8)\end{array}$ \\
\hline Log Mortality & $\begin{array}{l}-0.53 \\
(0.10)\end{array}$ & $\begin{array}{c}\text { anel B: } F \\
-0.42 \\
(0.11)\end{array}$ & $\begin{array}{c}\text { st-Stage fo } \\
-0.4 \\
(0.10)\end{array}$ & $\begin{array}{c}\text { Law and } \\
-0.35 \\
(0.10)\end{array}$ & $\begin{array}{c}\text { rder Trad } \\
-1 \\
(0.17)\end{array}$ & $\begin{array}{c}\text { on in } 199 \\
-0.9 \\
(0.18)\end{array}$ & $\begin{array}{l}-0.45 \\
(0.13)\end{array}$ & $\begin{array}{l}-0.34 \\
(0.13)\end{array}$ \\
\hline Latitude & & $\begin{array}{l}-0.40 \\
(0.11)\end{array}$ & & $\begin{array}{c}1.60 \\
(1.20)\end{array}$ & & $\begin{array}{l}-0.33 \\
(1.10)\end{array}$ & & $\begin{array}{c}2.4 \\
(1.04)\end{array}$ \\
\hline Asia Dummy & & & & & & & $\begin{array}{c}0.4 \\
(0.4)\end{array}$ & $\begin{array}{c}0.5 \\
(0.4)\end{array}$ \\
\hline Africa Dummy & & & & & & & $\begin{array}{l}-0.03 \\
(0.32)\end{array}$ & $\begin{array}{l}-0.001 \\
(0.30)\end{array}$ \\
\hline "Other" Continent Dummy & & & & & & & $\begin{array}{c}1.2 \\
(0.52)\end{array}$ & $\begin{array}{c}1 \\
(0.50)\end{array}$ \\
\hline Adjusted R-Squared & 0.3 & 0.35 & 0.17 & 0.19 & 0.5 & 0.52 & 0.34 & 0.38 \\
\hline Law and Order Tradition in 1995 & $\begin{array}{c}0.5 \\
(0.10)\end{array}$ & $\begin{array}{c}0.42 \\
(0.10)\end{array}$ & $\begin{array}{c}\text { Panel C: } \\
0.41 \\
(0.11)\end{array}$ & $\begin{array}{c}\text { dinary Le } \\
0.36 \\
(0.11)\end{array}$ & $\begin{array}{c}\text { st Square } \\
0.51 \\
(0.10)\end{array}$ & $\begin{array}{c}0.48 \\
(0.12)\end{array}$ & $\begin{array}{c}0.4 \\
(0.09)\end{array}$ & $\begin{array}{c}0.35 \\
(0.10)\end{array}$ \\
\hline Number of Observations & 63 & 63 & 59 & 59 & 36 & 36 & 63 & 63 \\
\hline
\end{tabular}

"Law and Order Tradition in 1995" is measured on a scale from 0 to 6, where a higher score means more law and order, from Political Risk Services (see Appendix Table A1 for more detail). Panel A reports the two stage least squares estimates with log GDP per capita (PPP basis) in 1995 as the dependent variable and instrumenting for law and order tradition using log settler mortality; Panel B reports the corresponding first stage. Panel C reports the OLS coefficient from regressing log GDP per capita on law and order tradition in 1995, with the other control variables indicated in that column (full results not reported to save space). Standard errors are in parentheses. In regressions with continent dummies, the dummy for America is omitted. 
Appendix Table A4c

IV Regressions of $\log$ GDP per capita

\begin{tabular}{|c|c|c|c|c|c|c|c|c|}
\hline & $\begin{array}{c}\text { Base } \\
\text { Sample } \\
\text { (1) }\end{array}$ & $\begin{array}{c}\text { Base } \\
\text { Sample } \\
(2)\end{array}$ & $\begin{array}{c}\text { Base } \\
\text { Sample } \\
\text { without } \\
\text { neo- } \\
\text { Europes } \\
\text { (3) }\end{array}$ & $\begin{array}{c}\text { Base } \\
\text { Sample } \\
\text { without } \\
\text { neo- } \\
\text { Europes } \\
\text { (4) }\end{array}$ & $\begin{array}{c}\text { Base } \\
\text { Sample } \\
\text { without } \\
\text { Africa } \\
\text { (5) }\end{array}$ & $\begin{array}{c}\text { Base } \\
\text { Sample } \\
\text { without } \\
\text { Africa } \\
\text { (6) }\end{array}$ & $\begin{array}{c}\text { Base } \\
\text { Sample } \\
\text { with } \\
\text { Continent } \\
\text { Dummies } \\
\text { (7) }\end{array}$ & $\begin{array}{c}\text { Base } \\
\text { Sample } \\
\text { with } \\
\text { Continent } \\
\text { Dummies } \\
\text { (8) }\end{array}$ \\
\hline \multicolumn{9}{|c|}{ Panel A: Two Stage Least Squares } \\
\hline Property Rights in 1997 & $\begin{array}{c}-1.6 \\
(0.33)\end{array}$ & $\begin{array}{c}-1.8 \\
(0.50)\end{array}$ & $\begin{array}{c}-2.1 \\
(0.80)\end{array}$ & $\begin{array}{c}-2.3 \\
(1.00)\end{array}$ & $\begin{array}{c}-0.9 \\
(0.15)\end{array}$ & $\begin{array}{c}-0.9 \\
(0.19)\end{array}$ & $\begin{array}{c}-1.3 \\
(0.46)\end{array}$ & $\begin{array}{c}-1.50 \\
(0.7)\end{array}$ \\
\hline Latitude & & $\begin{array}{c}-2 \\
(2.20)\end{array}$ & & $\begin{array}{c}-1.2 \\
(2.70)\end{array}$ & & $\begin{array}{c}-0.2 \\
(0.90)\end{array}$ & & $\begin{array}{l}-1.4 \\
(1.9)\end{array}$ \\
\hline Asia Dummy & & & & & & & $\begin{array}{l}-0.14 \\
(0.42)\end{array}$ & $\begin{array}{l}-0.14 \\
(0.50)\end{array}$ \\
\hline Africa Dummy & & & & & & & $\begin{array}{l}-0.44 \\
(0.44)\end{array}$ & $\begin{array}{l}-0.44 \\
(0.50)\end{array}$ \\
\hline "Other" Continent Dummy & & & & & & & $\begin{array}{l}-0.28 \\
(0.6)\end{array}$ & $\begin{array}{c}-0.23 \\
(0.6)\end{array}$ \\
\hline Log Mortality & $\begin{array}{c}0.37 \\
(0.10)\end{array}$ & $\begin{array}{l}\text { Panel } \\
0.28 \\
(0.10)\end{array}$ & $\begin{array}{c}\text { First-Sta } \\
0.2 \\
(0.10)\end{array}$ & $\begin{array}{c}\text { e for Prop } \\
0.2 \\
(0.11)\end{array}$ & $\begin{array}{c}\text { ty Rights } \\
-0.74 \\
(0.17)\end{array}$ & $\begin{array}{c}1997 \\
0.67 \\
(0.19)\end{array}$ & $\begin{array}{c}0.31 \\
(0.13)\end{array}$ & $\begin{array}{c}0.25 \\
(0.13)\end{array}$ \\
\hline Latitude & & $\begin{array}{l}-2.10 \\
(1.00)\end{array}$ & & $\begin{array}{l}-1.10 \\
(1.20)\end{array}$ & & $\begin{array}{l}-1.40 \\
(1.20)\end{array}$ & & $\begin{array}{c}-1.8 \\
(1.00)\end{array}$ \\
\hline Asia Dummy & & & & & & & $\begin{array}{c}0.5 \\
(0.4)\end{array}$ & $\begin{array}{c}0.4 \\
(0.4)\end{array}$ \\
\hline Africa Dummy & & & & & & & $\begin{array}{c}0.3 \\
(0.32)\end{array}$ & $\begin{array}{c}0.24 \\
(0.31)\end{array}$ \\
\hline "Other" Continent Dummy & & & & & & & $\begin{array}{l}-0.24 \\
(0.47)\end{array}$ & $\begin{array}{l}-0.13 \\
(0.47)\end{array}$ \\
\hline Adjusted R-Squared & 0.17 & 0.22 & 0.06 & 0.06 & 0.3 & 0.31 & 0.17 & 0.2 \\
\hline Property Rights in 1997 & $\begin{array}{l}-0.69 \\
(0.10)\end{array}$ & $\begin{array}{c}-0.6 \\
(0.10)\end{array}$ & $\begin{array}{c}\text { Panel C: } C \\
-0.6 \\
(0.10)\end{array}$ & $\begin{array}{c}\text { dinary Le } \\
-0.6 \\
(0.10)\end{array}$ & $\begin{array}{c}\text { t Squares } \\
-0.65 \\
(0.08)\end{array}$ & $\begin{array}{l}-0.62 \\
(0.08)\end{array}$ & $\begin{array}{l}-0.51 \\
(0.08)\end{array}$ & $\begin{array}{c}-0.5 \\
(0.08)\end{array}$ \\
\hline Number of Observations & 69 & 69 & 65 & 65 & 41 & 41 & 69 & 69 \\
\hline
\end{tabular}

"Property Rights in 1995" is measured on a scale from 1 to 5, where a higher score means less protection for property rights, from the Heritage Foundation (see Appendix Table A1 for more detail). Panel A reports the two stage least squares estimates with log GDP per capita (PPP basis) in 1995 as the dependent variable and instrumenting for property rights using $\log$ settler mortality; Panel B reports the corresponding first stage. Panel C reports the OLS coefficient from regressing log GDP per capita on property rights in 1995, with the other control variables indicated in that column (full results not reported to save space). Standard errors are in parentheses. In regressions with continent dummies, the dummy for America is omitted. 
Appendix Table A4d

IV Regressions of log GDP per capita

\begin{tabular}{|c|c|c|c|c|c|c|c|c|}
\hline & $\begin{array}{c}\text { Base } \\
\text { Sample } \\
\text { (1) }\end{array}$ & $\begin{array}{c}\text { Base } \\
\text { Sample } \\
(2)\end{array}$ & $\begin{array}{c}\text { Base } \\
\text { Sample } \\
\text { without } \\
\text { neo- } \\
\text { Europes } \\
\quad \text { (3) }\end{array}$ & $\begin{array}{c}\text { Base } \\
\text { Sample } \\
\text { without } \\
\text { neo- } \\
\text { Europes } \\
\text { (4) }\end{array}$ & $\begin{array}{c}\text { Base } \\
\text { Sample } \\
\text { without } \\
\text { Africa } \\
\text { (5) }\end{array}$ & $\begin{array}{c}\text { Base } \\
\text { Sample } \\
\text { without } \\
\text { Africa } \\
\text { (6) }\end{array}$ & $\begin{array}{c}\text { Base } \\
\text { Sample } \\
\text { with } \\
\text { Continent } \\
\text { Dummies } \\
\text { (7) }\end{array}$ & $\begin{array}{c}\text { Base } \\
\text { Sample } \\
\text { with } \\
\text { Continent } \\
\text { Dummies } \\
\text { (8) }\end{array}$ \\
\hline \multicolumn{9}{|c|}{ Panel A: Two Stage Least Squares } \\
\hline Rule of Law in 1995 & $\begin{array}{c}0.6 \\
(0.10)\end{array}$ & $\begin{array}{c}0.8 \\
(0.30)\end{array}$ & $\begin{array}{c}0.8 \\
(0.32)\end{array}$ & $\begin{array}{c}1.0 \\
(0.50)\end{array}$ & $\begin{array}{l}-0.37 \\
(0.12)\end{array}$ & $\begin{array}{c}0.5 \\
(0.27)\end{array}$ & $\begin{array}{c}0.6 \\
(0.20)\end{array}$ & $\begin{array}{l}0.75 \\
(0.4)\end{array}$ \\
\hline Latitude & & $\begin{array}{c}-3.9 \\
(3.50)\end{array}$ & & $\begin{array}{c}-3.7 \\
(4.50)\end{array}$ & & $\begin{array}{c}-4.2 \\
(3.60)\end{array}$ & & $\begin{array}{l}-2.9 \\
(3.3)\end{array}$ \\
\hline Asia Dummy & & & & & & & $\begin{array}{c}0.22 \\
(0.64)\end{array}$ & $\begin{array}{l}-0.25 \\
(0.81)\end{array}$ \\
\hline Africa Dummy & & & & & & & $\begin{array}{l}-0.38 \\
(0.50)\end{array}$ & $\begin{array}{l}-0.35 \\
(0.66)\end{array}$ \\
\hline "Other" Continent Dummy & & & & & & & $\begin{array}{l}-1.6 \\
(1.0)\end{array}$ & $\begin{array}{l}-1.9 \\
(1.4)\end{array}$ \\
\hline Log Mortality & $\begin{array}{c}-1.1 \\
(0.30)\end{array}$ & $\begin{array}{c}\text { Pane } \\
-0.8 \\
(0.30)\end{array}$ & $\begin{array}{c}\text { B: First }-S \\
-0.8 \\
(0.30)\end{array}$ & $\begin{array}{c}\text { Ige for } R u \\
\quad-0.6 \\
(0.32)\end{array}$ & $\begin{array}{c}\text { of Law ir } \\
\quad-1.7 \\
(0.60)\end{array}$ & $\begin{array}{l}1995 \\
-1.1 \\
(0.55)\end{array}$ & $\begin{array}{c}-1 \\
(0.35)\end{array}$ & $\begin{array}{l}-0.75 \\
(0.38)\end{array}$ \\
\hline Latitude & & $\begin{array}{l}6.30 \\
(2.80)\end{array}$ & & $\begin{array}{c}4.50 \\
(3.20)\end{array}$ & & $\begin{array}{l}9.70 \\
(3.40)\end{array}$ & & $\begin{array}{c}4.9 \\
(2.80)\end{array}$ \\
\hline Asia Dummy & & & & & & & $\begin{array}{l}-1.7 \\
(1.0)\end{array}$ & $\begin{array}{l}-1.3 \\
(1.1)\end{array}$ \\
\hline Africa Dummy & & & & & & & $\begin{array}{l}-0.31 \\
(0.80)\end{array}$ & $\begin{array}{c}-0.3 \\
(0.80)\end{array}$ \\
\hline "Other" Continent Dummy & & & & & & & $\begin{array}{c}2.4 \\
(1.30)\end{array}$ & $\begin{array}{c}2.2 \\
(1.30)\end{array}$ \\
\hline Adjusted R-Squared & 0.2 & 0.25 & 0.08 & 0.1 & 0.18 & 0.31 & 0.25 & 0.28 \\
\hline Rule of Law in 1995 & $\begin{array}{c}0.18 \\
(0.04)\end{array}$ & $\begin{array}{c}0.13 \\
(0.04)\end{array}$ & $\begin{array}{c}\text { Panel } C: \text { C } \\
0.14 \\
(0.04)\end{array}$ & $\begin{array}{c}\text { dinary Le } \\
0.11 \\
(0.04)\end{array}$ & $\begin{array}{c}\text { Squares } \\
0.14 \\
(0.04)\end{array}$ & $\begin{array}{c}0.13 \\
(0.05)\end{array}$ & $\begin{array}{c}0.13 \\
(0.04)\end{array}$ & $\begin{array}{c}0.1 \\
(0.04)\end{array}$ \\
\hline Number of Observations & 65 & 65 & 61 & 61 & 38 & 38 & 65 & 65 \\
\hline
\end{tabular}

"Rule of Law in 1995" is measured on a scale from 0 to 10, where a higher score means stronger rule of law, from the Fraser Institute (see Appendix Table A1 for more detail). Panel A reports the two stage least squares estimates with log GDP per capita (PPP basis) in 1995 as the dependent variable and instrumenting for rule of law using log settler mortality; Panel B reports the corresponding first stage. Panel C reports the OLS coefficient from regressing log GDP per capita on rule of law in 1995, with the other control variables indicated in that column (full results not reported to save space). Standard errors are in parentheses. In regressions with continent dummies, the dummy for America is omitted. 
Appendix Table A4e

IV Regressions of log GDP per capita

\begin{tabular}{|c|c|c|c|c|c|c|c|c|}
\hline & $\begin{array}{c}\text { Base } \\
\text { Sample } \\
(1) \\
\end{array}$ & $\begin{array}{c}\text { Base } \\
\text { Sample } \\
(2)\end{array}$ & $\begin{array}{c}\text { Base } \\
\text { Sample } \\
\text { without } \\
\text { neo- } \\
\text { Europes } \\
\quad(3) \\
\end{array}$ & $\begin{array}{c}\text { Base } \\
\text { Sample } \\
\text { without } \\
\text { neo- } \\
\text { Europes } \\
\quad(4) \\
\end{array}$ & $\begin{array}{c}\text { Base } \\
\text { Sample } \\
\text { without } \\
\text { Africa } \\
(5) \\
\end{array}$ & $\begin{array}{c}\text { Base } \\
\text { Sample } \\
\text { without } \\
\text { Africa } \\
(6) \\
\end{array}$ & $\begin{array}{c}\text { Base } \\
\text { Sample } \\
\text { with } \\
\text { Continent } \\
\text { Dummies } \\
(7) \\
\end{array}$ & $\begin{array}{c}\text { Base } \\
\text { Sample } \\
\text { with } \\
\text { Continent } \\
\text { Dummies } \\
\quad(8) \\
\end{array}$ \\
\hline \multicolumn{9}{|c|}{ Panel A: Two Stage Least Squares } \\
\hline $\begin{array}{l}\text { Efficiency of the Judiciary } \\
1980-83\end{array}$ & $\begin{array}{c}0.62 \\
(0.12)\end{array}$ & $\begin{array}{c}0.56 \\
(0.12)\end{array}$ & $\begin{array}{l}0.74 \\
(0.24)\end{array}$ & $\begin{array}{c}0.7 \\
(0.20)\end{array}$ & $\begin{array}{c}0.41 \\
(0.08)\end{array}$ & $\begin{array}{c}0.36 \\
(0.08)\end{array}$ & $\begin{array}{c}0.66 \\
(0.15)\end{array}$ & $\begin{array}{l}0.61 \\
(0.1)\end{array}$ \\
\hline Latitude & & $\begin{array}{c}-1 \\
(1.00)\end{array}$ & & $\begin{array}{c}2.1 \\
(1.40)\end{array}$ & & $\begin{array}{c}1.3 \\
(0.80)\end{array}$ & & $\begin{array}{l}0.75 \\
(1.0)\end{array}$ \\
\hline Asia Dummy & & & & & & & $\begin{array}{l}-0.89 \\
(0.37)\end{array}$ & $\begin{array}{l}-0.81 \\
(0.35)\end{array}$ \\
\hline Africa Dummy & & & & & & & $\begin{array}{l}-0.40 \\
(0.37)\end{array}$ & $\begin{array}{l}-0.41 \\
(0.34)\end{array}$ \\
\hline "Other" Continent Dummy & & & & & & & $\begin{array}{l}-1.4 \\
(0.7)\end{array}$ & $\begin{array}{l}-1.3 \\
(0.6)\end{array}$ \\
\hline Log Mortality & $\begin{array}{c}-1 \\
(0.23)\end{array}$ & $\begin{array}{c}\text { Inel } B: F i \\
-1 \\
(0.26)\end{array}$ & $\begin{array}{c}\text {-Stage for } \\
-0.74 \\
(0.28)\end{array}$ & $\begin{array}{c}\text { Efficiency } \\
-0.83 \\
(0.28)\end{array}$ & $\begin{array}{c}\text { f the Judi } \\
-1.9 \\
(0.28)\end{array}$ & $\begin{array}{c}\text { ry } 1980-8 \\
-1.9 \\
(0.30)\end{array}$ & $\begin{array}{cc}3 & \\
& -0.9 \\
& (0.26)\end{array}$ & $\begin{array}{c}-1 \\
(0.30)\end{array}$ \\
\hline Latitude & & $\begin{array}{l}-0.41 \\
(2.10)\end{array}$ & & $\begin{array}{l}-3.00 \\
(2.50)\end{array}$ & & $\begin{array}{l}-2.10 \\
(1.70)\end{array}$ & & $\begin{array}{c}-1.2 \\
(2.00)\end{array}$ \\
\hline Asia Dummy & & & & & & & $\begin{array}{l}-0.9 \\
(0.4)\end{array}$ & $\begin{array}{l}-0.1 \\
(0.7)\end{array}$ \\
\hline Africa Dummy & & & & & & & $\begin{array}{c}-0.4 \\
(0.40)\end{array}$ & $\begin{array}{l}-0.12 \\
(0.70)\end{array}$ \\
\hline "Other" Continent Dummy & & & & & & & $\begin{array}{c}1.4 \\
(0.70)\end{array}$ & $\begin{array}{c}2.2 \\
(1.00)\end{array}$ \\
\hline Adjusted R-Squared & 0.51 & 0.32 & 0.16 & 0.17 & 0.6 & 0.61 & 0.37 & 0.36 \\
\hline $\begin{array}{l}\text { Efficiency of the Judiciary } \\
1980-83\end{array}$ & $\begin{array}{c}0.36 \\
(0.06)\end{array}$ & $\begin{array}{c}0.33 \\
(0.06)\end{array}$ & $\begin{array}{c}\text { Panel C: C } \\
\quad 0.3 \\
(0.07)\end{array}$ & $\begin{array}{c}\text { dinary Le } \\
0.3 \\
(0.07)\end{array}$ & $\begin{array}{c}\text { squares } \\
0.36 \\
(0.06)\end{array}$ & $\begin{array}{c}0.35 \\
(0.06)\end{array}$ & $\begin{array}{c}0.35 \\
(0.06)\end{array}$ & $\begin{array}{c}0.33 \\
(0.05)\end{array}$ \\
\hline Number of Observations & 38 & 38 & 34 & 34 & 27 & 27 & 38 & 38 \\
\hline
\end{tabular}

"Efficiency of the Judiciary 1980-83" is measured on a scale from 1 to 10, where a higher score means a more efficient judiciary, from Business International (see Appendix Table A1 for more detail). Panel A reports the two stage least squares estimates with log GDP per capita (PPP basis) in 1995 as the dependent variable and instrumenting for efficiency of the judiciary using log settler mortality; Panel B reports the corresponding first stage. Panel C reports the OLS coefficient from regressing log GDP per capita on efficiency of the judiciary, with the other control variables indicated in that column (full results not reported to save space). Standard errors are in parentheses. In regressions with continent dummies, the dummy for America is omitted. 


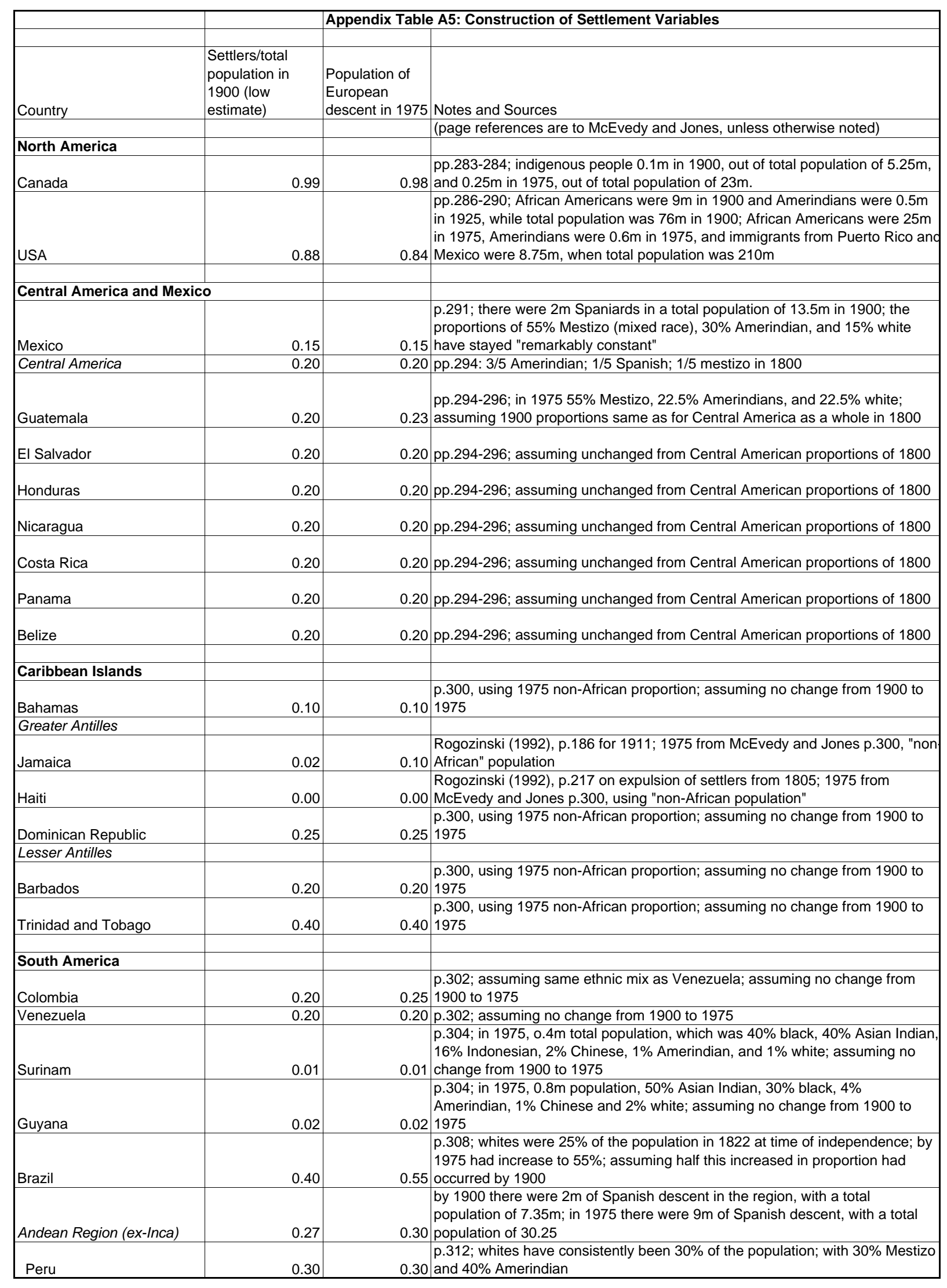




\begin{tabular}{|c|c|c|c|}
\hline Country & $\begin{array}{l}\text { Settlers/total } \\
\text { population in } \\
1900 \text { (low } \\
\text { estimate) }\end{array}$ & $\begin{array}{l}\text { Population of } \\
\text { European } \\
\text { descent in } 1975\end{array}$ & Notes and Sources \\
\hline Ecuador & 0.30 & 0.30 & $\begin{array}{l}\text { p.312; whites have consistently been } 30 \% \text { of the population; with } 30 \% \text { Mestizo } \\
\text { and } 40 \% \text { Amerindian }\end{array}$ \\
\hline Bolivia & 0.30 & 0.30 & $\begin{array}{l}\text { p.312; whites have consistently been } 30 \% \text { of the population; with } 30 \% \text { Mestizo } \\
\text { and } 40 \% \text { Amerindian }\end{array}$ \\
\hline Paraguay & 0.25 & 0.25 & $\begin{array}{l}\text { p.312; only } 30,000 \text { Amerindians in } 1975 \text {, out of total population of } 2.5 \mathrm{~m}, 75 \% \\
\text { mestizos and } 25 \% \text { white; two thirds of adult male population died or } \\
\text { disappeared due to war in } 1865-1870 \text {; assuming no change in composition of } \\
\text { population from } 1900 \text { to } 1975\end{array}$ \\
\hline Argentina & 0.60 & 0.90 & $\begin{array}{l}\text { p. } 313-4 ; 30 \% \text { of population was foreign born in } 1914 \text { census (p.313); in } 1975 \\
\text { only } 10 \% \text { of population had Indian or mixed ancestry; white population was } \\
0.15 \mathrm{~m} \text {, Indians were } 0.35 \mathrm{~m} \text {, and Mestizos were } 0.75 \mathrm{~m} \text { in } 1825 \text { (for Argentina } \\
\text { and Chile combined); most immigrants arrived after } 1880 \mathrm{~s} \text {, with peak years in } \\
1910 \mathrm{~s} \text {. White population was } 15 \mathrm{~m} \text { out of total of } 17 \mathrm{~m} \text { in } 1950 \text {. Population was } \\
4.75 \mathrm{~m} \text { in } 1900 \text {; we assume } 50 \% \text { white population in } 1900 \text { (above that of Chile). }\end{array}$ \\
\hline Chile & 0.50 & 0.50 & $\begin{array}{l}\text { p.313-4; never more than } 5 \% \text { foreign born in any census (p.313); in Chile, } \\
\text { population equally divided in } 1975 \text { between whites and those of Indian or } \\
\text { mixed descent; since } 1850 \text { Argentina has received at least } 2.5 \mathrm{~m} \text { net } \\
\text { immigrants, while Chile has only received } 0.2 \mathrm{~m}\end{array}$ \\
\hline Uruguay & 0.60 & 0.90 & p.313-4; assuming same ethnic mix as Argentina \\
\hline \multicolumn{4}{|l|}{ Oceania } \\
\hline Australia & 0.98 & 0.99 & $\begin{array}{l}\text { pp.327-8; } 60,000 \text { aborigines out of population of } 3.75 \mathrm{~m} \text { in } 1900 ; 80,000 \\
\text { aborigines out of population of } 13.5 \mathrm{~m} \text { in } 1975 .\end{array}$ \\
\hline New Zealand & 0.93 & 0.92 & $\begin{array}{l}\text { pp.337-8; } 42,000 \text { Maori "in the } 1890 \mathrm{~s} " \text {, total population of } 750,000 \text { in } 1900 \text {; } \\
250,000 \text { Maori in } 1975 \text {, out of total population of } 3 \mathrm{~m} \text {. }\end{array}$ \\
\hline \multicolumn{4}{|l|}{ Africa } \\
\hline \multicolumn{4}{|l|}{ The Maghreb } \\
\hline Morocco & 0.01 & 0.00 & $\begin{array}{l}\text { assuming half of settlers in non-Algerian Mahgreb went to Morocco (p.220); In } \\
1956 \text { Europeans were } 5.4 \text { percent in former French Morocco (Curtin et al } \\
1995, \text { p.435); most left by end of 1960s }\end{array}$ \\
\hline Algeria & 0.13 & 0.00 & $\begin{array}{l}\text { p.220; In } 1956 \text { Europeans were } 10.9 \text { percent in Algeria (Curtin et al 1995, } \\
\text { p.435); most left by end of 1960s }\end{array}$ \\
\hline Tunisia & 0.03 & 0.00 & $\begin{array}{l}\text { assuming half of settlers in non-Algerian Mahgreb went to Tunisia; In } 1956 \\
\text { Europeans were } 6.7 \text { percent (Curtin et al 1995, p.435), most left by end of } \\
\text { 1960s }\end{array}$ \\
\hline Libya & 0.00 & 0.00 & in 1956 no Europeans (Curtin et al 1995) \\
\hline Egypt & 0.01 & 0.00 & $\begin{array}{l}\text { p.226; in } 1882 \text { Egypt had a population of } 6,800,000 \text { of which } 90,000 \text { were } \\
\text { foreigners (Curtin 1998, p.127); most left by end of } 1960 \text { s }\end{array}$ \\
\hline Ethiopia & 0.00 & 0.00 & p.230; in 1956 no Europeans (Curtin et al 1995, p.435) \\
\hline Sudan & 0.00 & 0.00 & pp.235-236; in 1956 no Europeans (Curtin et al 1995) \\
\hline \multicolumn{4}{|l|}{ Sahel States } \\
\hline Mauritania & 0.00 & 0.00 & pp.238-240; in 1956 no Europeans (Curtin et al 1995) \\
\hline Mali & 0.00 & 0.00 & pp.238-240; in 1956 no Europeans (Curtin et al 1995) \\
\hline Niger & 0.00 & 0.00 & pp.238-240; in 1956 no Europeans (Curtin et al 1995) \\
\hline Chad & 0.00 & 0.00 & pp.238-240; in 1956 no Europeans (Curtin et al 1995) \\
\hline \multicolumn{4}{|l|}{ West Africa } \\
\hline Senegal & 0.00 & 0.00 & pp.241-246; in 1956 no Europeans (Curtin et al 1995) \\
\hline Gambia & 0.00 & 0.00 & pp.241-246; in 1956 no Europeans (Curtin et al 1995) \\
\hline Guinea-Bissau & 0.00 & 0.00 & pp.241-246; in 1956 no Europeans (Curtin et al 1995) \\
\hline Guinea-Conakry & 0.00 & 0.00 & pp.241-246; in 1956 no Europeans (Curtin et al 1995) \\
\hline Sierra Leone & 0.00 & 0.00 & pp.241-246; in 1956 no Europeans (Curtin et al 1995) \\
\hline Liberia & 0.00 & 0.00 & pp.241-246; in 1956 no Europeans (Curtin et al 1995) \\
\hline Ivory Coast & 0.00 & 0.00 & pp.241-246; in 1956 no Europeans (Curtin et al 1995) \\
\hline Ghana & 0.00 & 0.00 & pp.241-246; in 1956 no Europeans (Curtin et al 1995) \\
\hline Togo & 0.00 & 0.00 & pp.241-246; in 1956 no Europeans (Curtin et al 1995) \\
\hline Benin & 0.00 & 0.00 & pp.241-246; in 1956 no Europeans (Curtin et al 1995) \\
\hline Nigeria & 0.00 & 0.00 & pp.241-246; in 1956 no Europeans (Curtin et al 1995) \\
\hline Upper Volta & 0.00 & 0.00 & pp.241-246; in 1956 no Europeans (Curtin et al 1995) \\
\hline \multicolumn{4}{|l|}{ Central-West Africa } \\
\hline Equatoria & 0.00 & 0.00 & pp.247-248; in 1956 no Europeans (Curtin et al 1995) \\
\hline Cameroon & 0.00 & 0.00 & pp.247-248; in 1956 no Europeans (Curtin et al 1995) \\
\hline Central African Republic & 0.00 & 0.00 & pp.247-248; in 1956 no Europeans (Curtin et al 1995) \\
\hline Gabon & 0.00 & 0.00 & pp.247-248; in 1956 no Europeans (Curtin et al 1995) \\
\hline Congo & 0.00 & 0.00 & pp.247-248; in 1956 no Europeans (Curtin et al 1995) \\
\hline
\end{tabular}




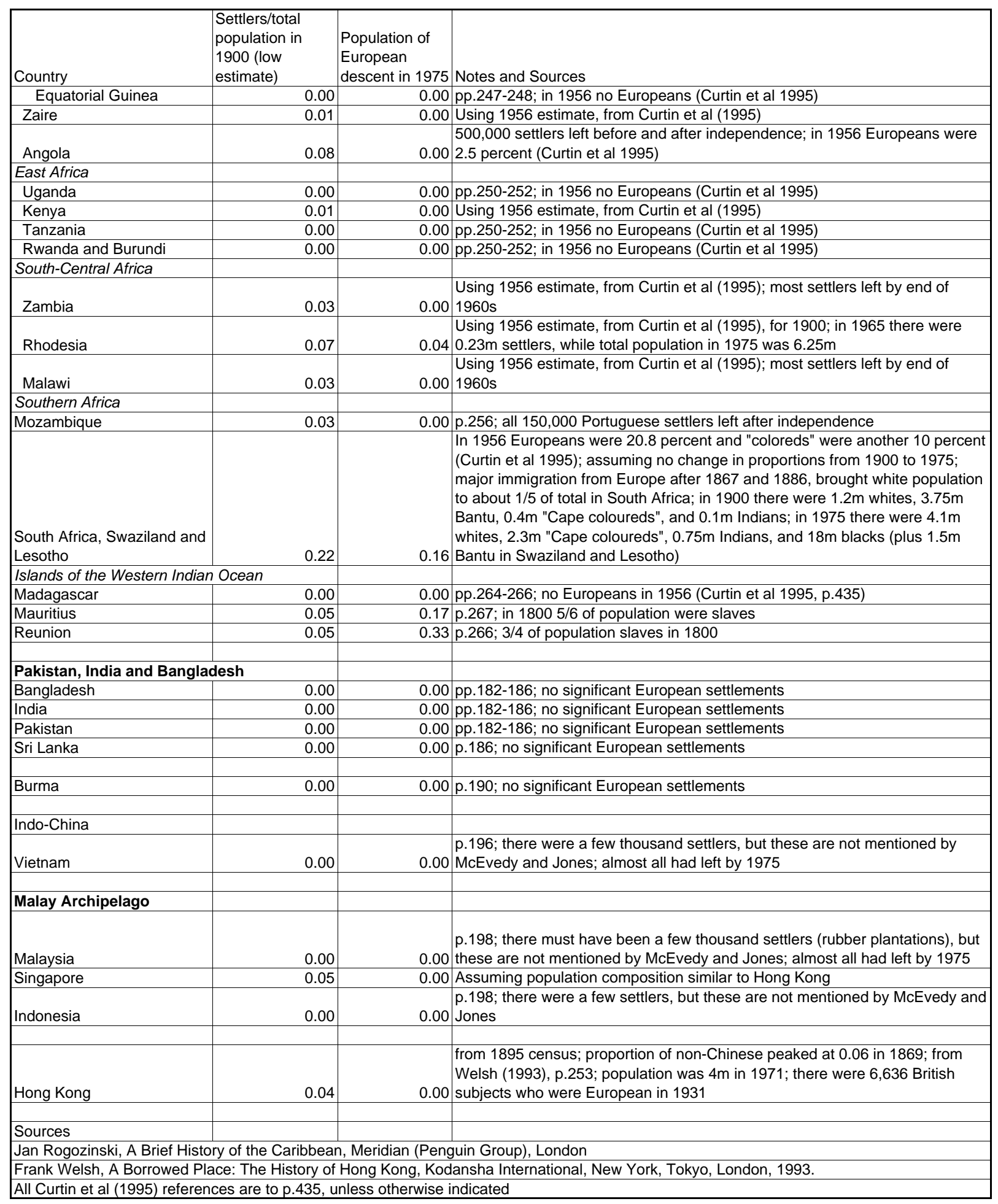




\section{Figure 1}

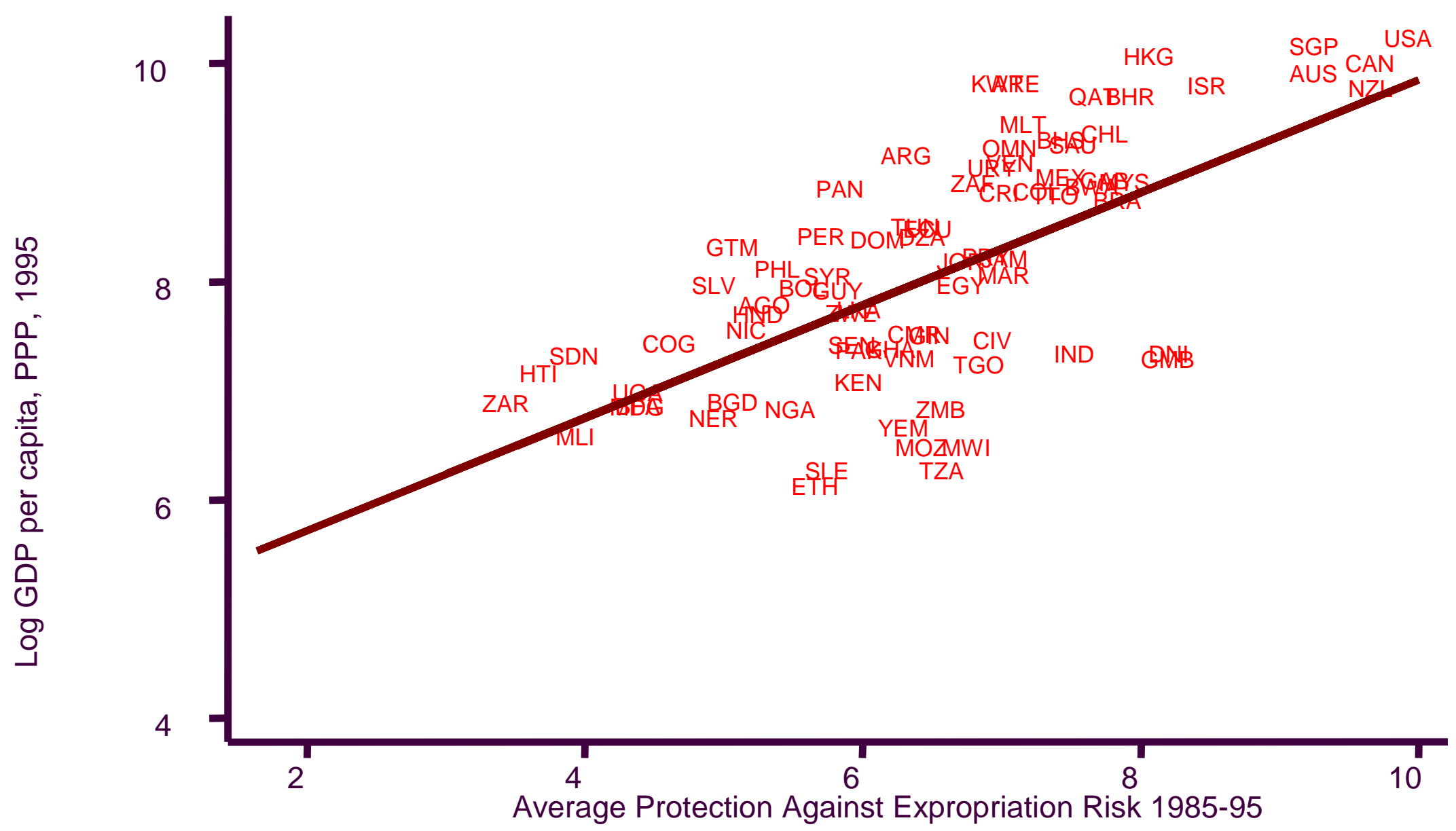


Figure 2

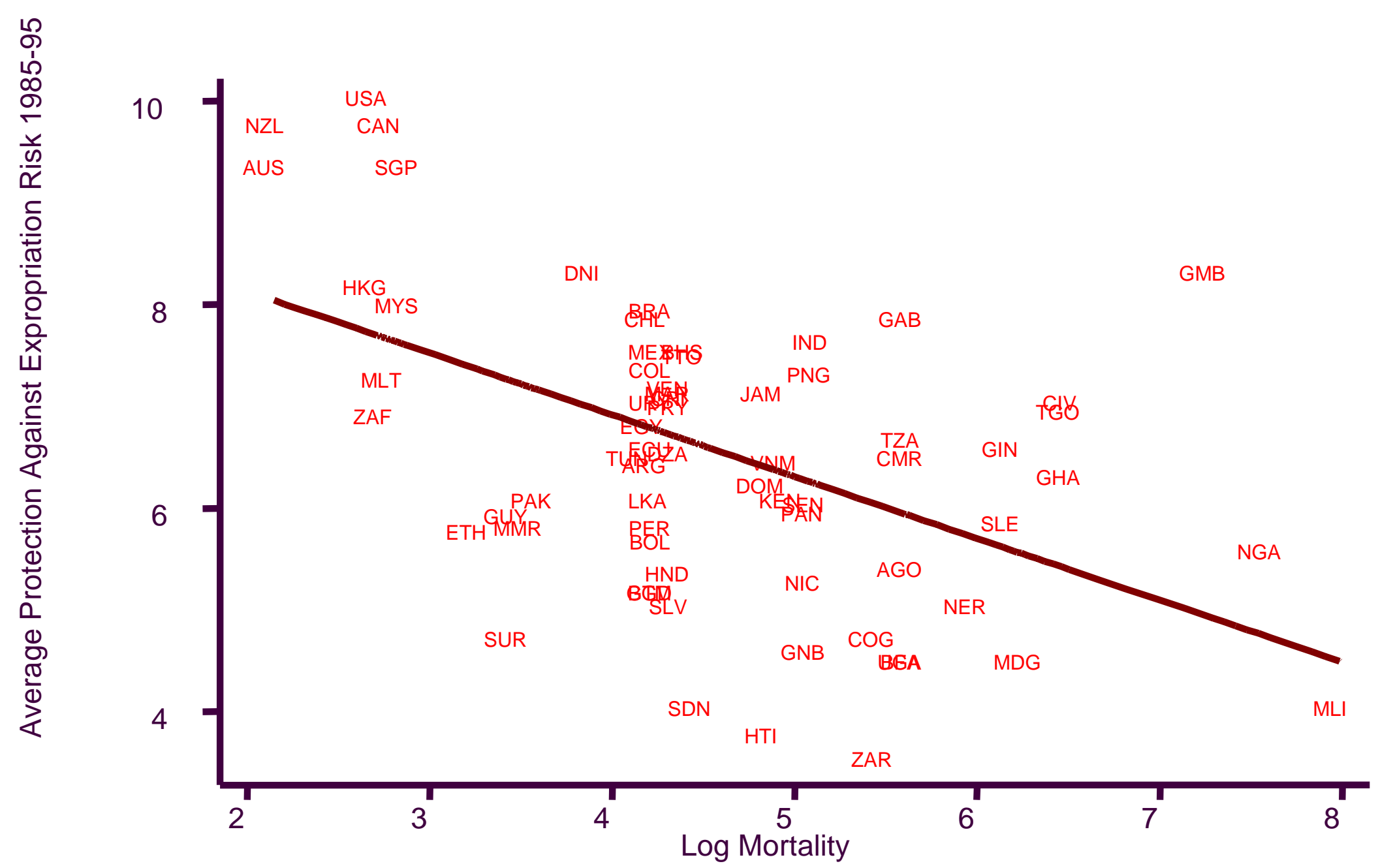


Figure 3

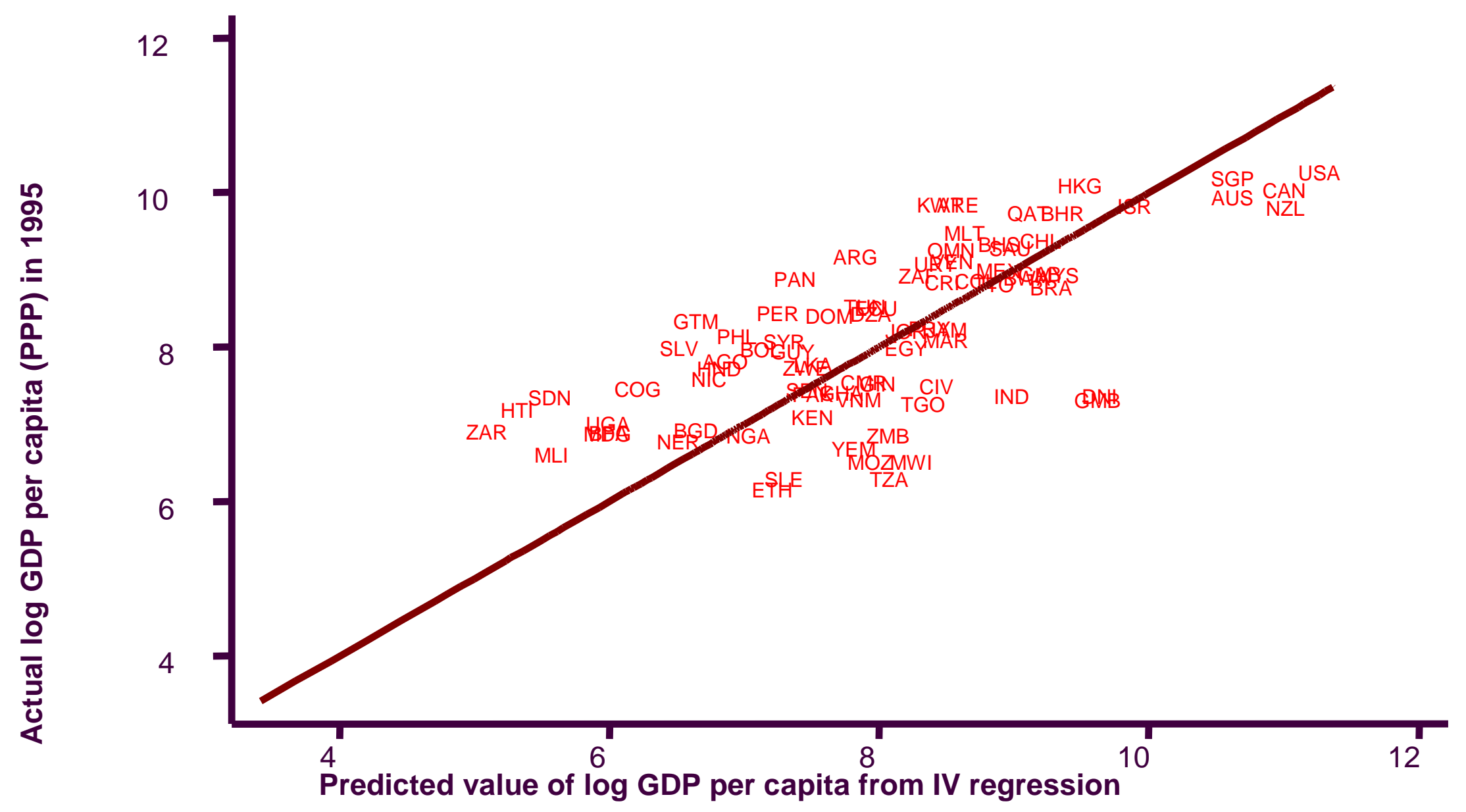

